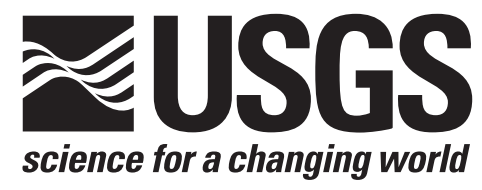

\title{
REPORT OF THE RIVER MASTER OF THE DELAWARE RIVER \\ FOR THE PERIOD \\ DECEMBER 1, 2005-NOVEMBER 30, 2006
}

Open-File Report 2011-1177 


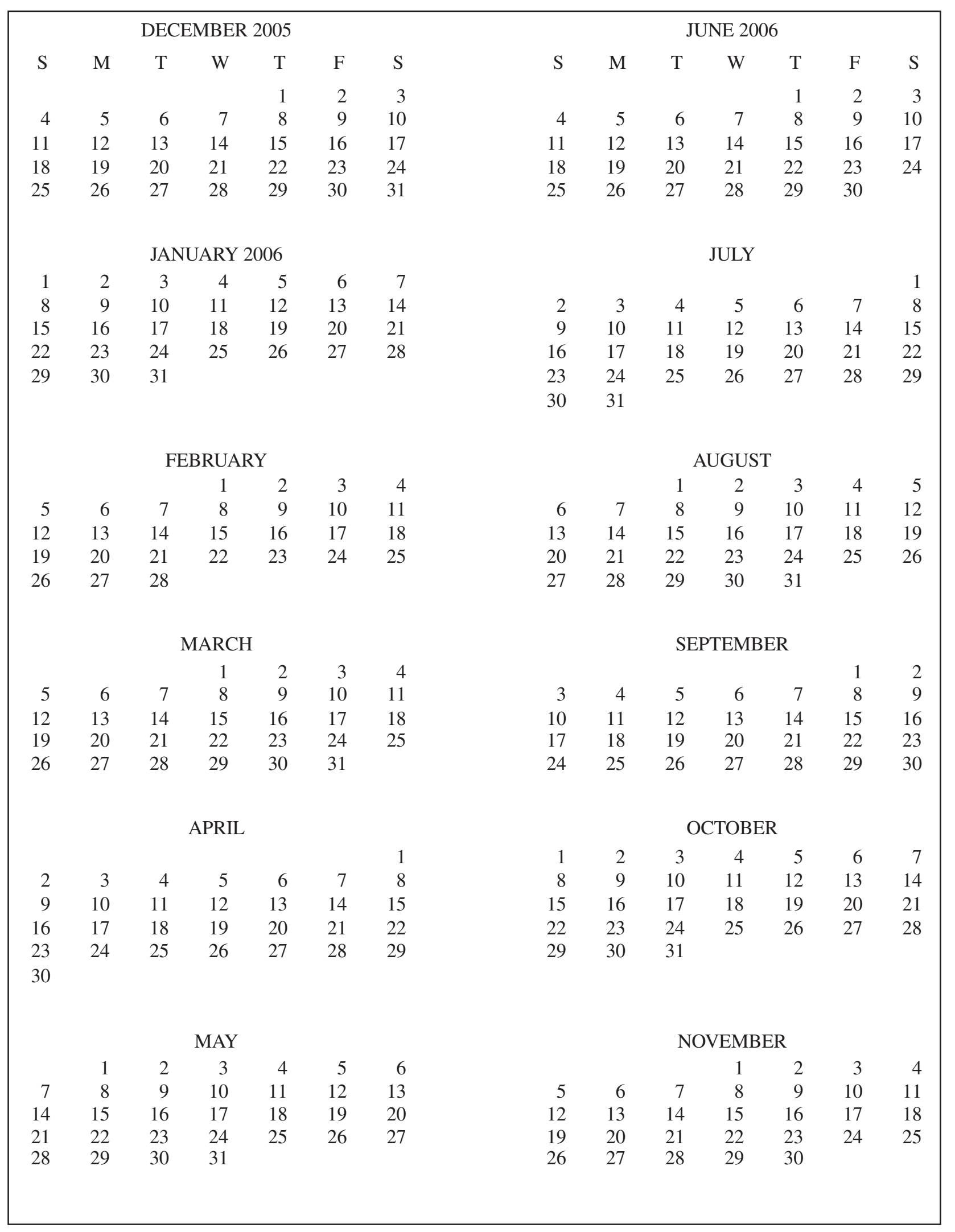




\section{Report of the River Master of the Delaware River for the period December 1, 2005-November 30, 2006}

By Bruce E. Krejmas, Gary N. Paulachok, and Stephen F. Blanchard

Open-File Report 2011-1177 


\section{U.S. Department of the Interior \\ KEN SALAZAR, Secretary \\ U.S. Geological Survey \\ Marcia K. McNutt, Director}

U.S. Geological Survey, Reston, Virginia: 2011

For more information about the USGS and its products:

Telephone: 1-888-ASK-USGS

World Wide Web: http://www.usgs.gov/

\footnotetext{
Any use of trade, product, or firm names in this publication is for descriptive purposes only and does not imply endorsement by the U.S. Government.

Although this report is in the public domain, permission must be secured from the individual copyright owners to reproduce any copyrighted materials contained within this report.

Suggested citation:

Krejmas, B.E., Paulachok, G.N., and Blanchard, S.F., 2010, Report of the River Master of the Delaware River for the period December 1, 2005-November 30, 2006: U.S. Geological Survey Open-File Report 2011-1177, 79 p.
} 


\section{Contents}

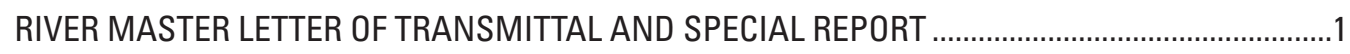

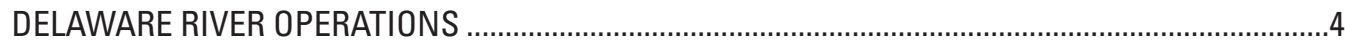

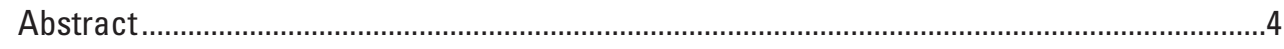

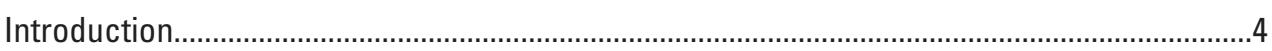

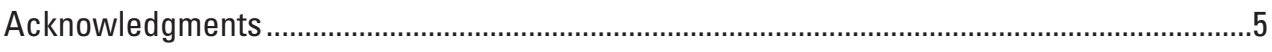

Definition of Terms and Procedures ................................................................................

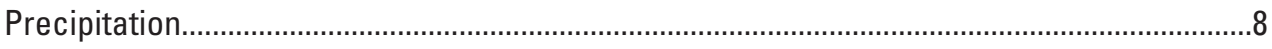

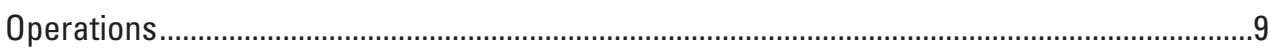

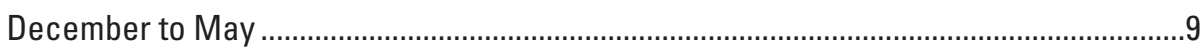

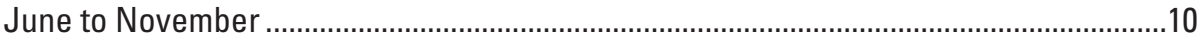

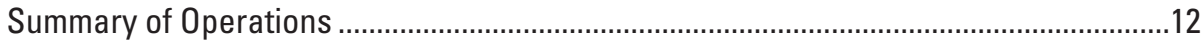

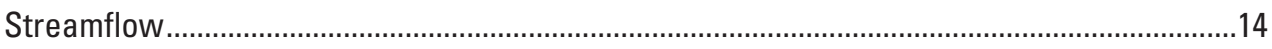

Components of Flow, Delaware River at Montague, New Jersey..................................14

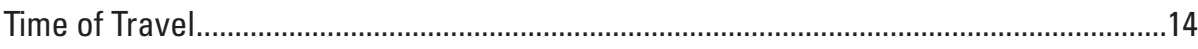

Segregation of Flow at Montague ..............................................................................15

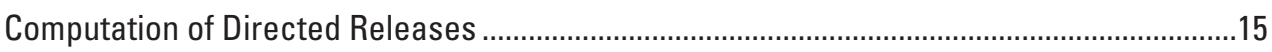

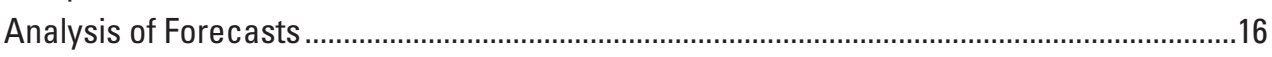

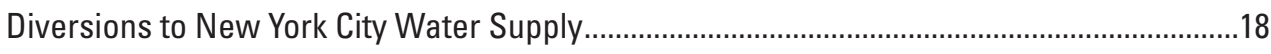

Storage in New York City Reservoirs................................................................................18

Comparison of River Master Operations Data With Other Streamflow Records.....................19

Releases from New York City Reservoirs.........................................................................19

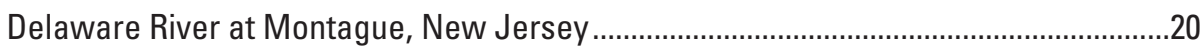

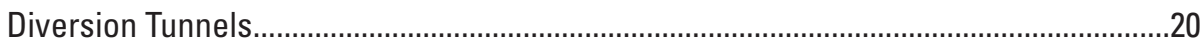

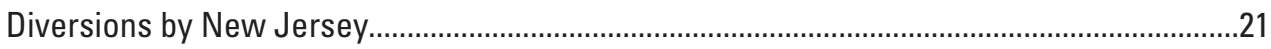

Conformance of Operations Under the Amended Decree of the U.S. Supreme Court ...........22

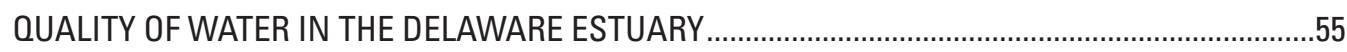

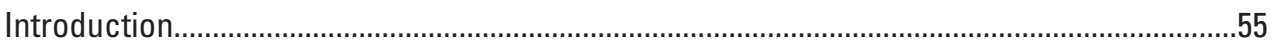

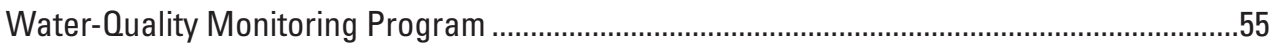

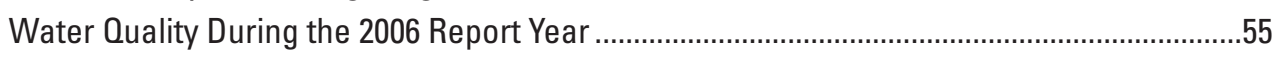

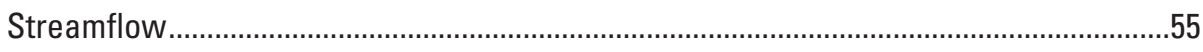

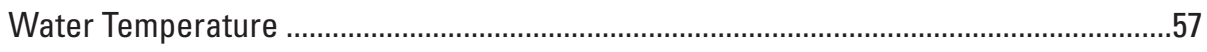

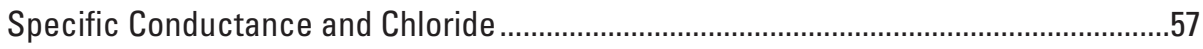

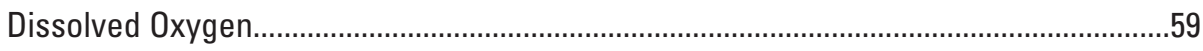

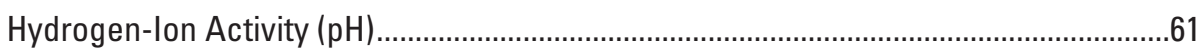

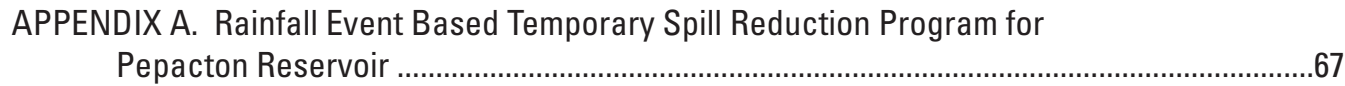

APPENDIX B. Rainfall Event Based Temporary Spill Reduction Program for

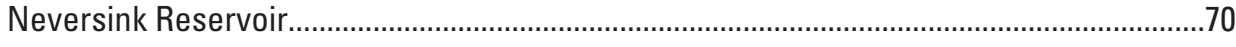

APPENDIX C. DRBC Docket No. D-77-20-CP (Revision 9) .............................................................. 


\section{Figures}

Figure 1. Map showing Delaware River Basin above Wilmington, Delaware....................................6

Figure 2. Graph showing operation curves and actual contents for New York City reservoirs in the Delaware River Basin, December 1, 2005, to November 30, 2006 ............................7

Figure 3. Components of flow, Delaware River at Montague, New Jersey, August 1 to August 31, 2006. . .12

Figure 4. Boxplots showing combined storage in Pepacton, Cannonsville, and Neversink

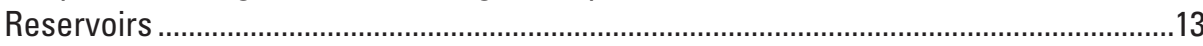

Figure 5. Hydrograph of uncontrolled runoff component, Delaware River at Montague, New Jersey, August 2006 ................................................................................................17

Figure 6. Map showing location of water-quality monitoring sites on the Delaware Estuary.......56 Figures 7-9. Graphs showing:

7. Water temperature in the Delaware Estuary at Benjamin Franklin Bridge at Philadelphia, Pennsylvania, April to November.

8. Mean and minimum daily mean dissolved-oxygen concentrations from July to September at two monitor sites on the Delaware Estuary, 1965-2006. 60

9. Distribution of hourly dissolved-oxygen concentrations at two monitor sites on the Delaware Estuary, July to September, 2006

\section{Tables}

Table 1. Precipitation in the Delaware River Basin above Montague, New Jersey.

Table 2. Conservation release rates for New York City reservoirs in the Delaware River Basin ..23 Tables 3-5. Storage in:

3. Pepacton Reservoir, New York .24

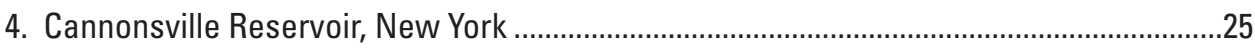

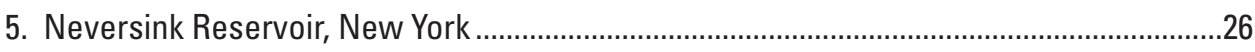

Table 6. Design rates for Delaware River at Montague, New Jersey, gaging station ....................27

Table 7. Consumption of water by New York City, 1950 to 2006..................................................28

Table 8. New York City reservoir release design data .....................................................................30

Table 9. Controlled releases from reservoirs in the upper Delaware River Basin and segregation of flow of Delaware River at Montague, New Jersey ......................................................32

Table 10. Diversions to New York City water-supply system ..........................................................4

Tables 11-14. Daily mean discharge:

11. East Branch Delaware River at Downsville, New York ……..........................................50

12. West Branch Delaware River at Stilesville, New York ...................................................51

13. Neversink River at Neversink, New York...............................................................52

14. Delaware River at Montague, New Jersey ................................................................53

Table 15. Diversions by New Jersey; daily mean discharge, Delaware and Raritan Canal at Port Mercer, New Jersey ......................................................................................54

Table 16. Daily mean discharge, Delaware River at Trenton, New Jersey .......................................62

Tables 17-18. Daily maximum and minimum chloride concentrations:

17. Delaware River at Reedy Island Jetty, Delaware...........................................................63

18. Delaware River at Chester, Pennsylvania..........................................................................64 
Tables 19-20. Daily mean dissolved-oxygen concentration:

19. Delaware River at Benjamin Franklin Bridge at Philadelphia, Pennsylvania ..................65

20. Delaware River at Chester, Pennsylvania......................................................................66 


\begin{tabular}{|c|c|c|}
\hline Multiply & By & To obtain \\
\hline \multicolumn{3}{|c|}{ Length } \\
\hline $\begin{array}{r}\text { inch (in.) } \\
\text { foot (ft) } \\
\text { mile (mi) }\end{array}$ & $\begin{array}{l}25.4 \\
0.3048 \\
1.609\end{array}$ & $\begin{array}{l}\text { millimeter }(\mathrm{mm}) \\
\text { meter }(\mathrm{m}) \\
\text { kilometer }(\mathrm{km})\end{array}$ \\
\hline \multicolumn{3}{|c|}{ Area } \\
\hline \multirow[t]{2}{*}{ square mile $\left(\mathrm{mi}^{2}\right)$} & 2.590 & square kilometer $\left(\mathrm{km}^{2}\right)$ \\
\hline & Volume & \multirow{6}{*}{$\begin{array}{l}\text { cubic meter }\left(\mathrm{m}^{3}\right) \\
\text { cubic foot per second day }\left(\mathrm{ft}^{3} / \mathrm{s}\right)-\mathrm{c} \\
\text { cubic hectometer }\left(\mathrm{hm}^{3}\right) \\
\text { cubic hectometer }\left(\mathrm{hm}^{3}\right)\end{array}$} \\
\hline million gallons (Mgal) & 3,785 & \\
\hline million gallons (Mgal) & 1.547 & \\
\hline billion gallons (Bgal) & 3.785 & \\
\hline cubic foot per second day $\left(\mathrm{ft}^{3} / \mathrm{s}\right)-\mathrm{d}$ & 0.002447 & \\
\hline \multicolumn{2}{|r|}{ Flow rate } & \\
\hline million gallons per day (Mgal/d) & 1.547 & cubic foot per second $\left(\mathrm{ft}^{3} / \mathrm{s}\right)$ \\
\hline million gallons per day (Mgal/d) & 0.04381 & cubic meter per second $\left(\mathrm{m}^{3} / \mathrm{s}\right)$ \\
\hline billion gallons per day (Bgal/d) & 43.81 & cubic meter per second $\left(\mathrm{m}^{3} / \mathrm{s}\right)$ \\
\hline cubic foot per second $\left(\mathrm{ft}^{3} / \mathrm{s}\right)$ & 0.02832 & cubic meter per second $\left(\mathrm{m}^{3} / \mathrm{s}\right)$ \\
\hline
\end{tabular}

Datum: Vertical coordinate information is referenced to the North American Vertical Datum of 1988. Horizontal coordinate information is referenced to the North American Datum of 1983.

Elevation, as used in this report, refers to the distance above a vertical datum.

Temperature in degrees Celsius $\left({ }^{\circ} \mathrm{C}\right)$ may be converted to degrees Fahrenheit $\left({ }^{\circ} \mathrm{F}\right)$ as follows: ${ }^{\circ} \mathrm{F}=\left(1.8 \mathrm{x}^{\circ} \mathrm{C}\right)+32$

\section{CHEMICAL CONCENTRATIONS}

In this report, concentrations of chloride and dissolved oxygen are given in milligrams per liter (mg/L). Milligrams per liter represents the mass of solute (milligrams) per unit volume (liter) of water. 


\title{
RIVER MASTER LETTER OF TRANSMITTAL AND SPECIAL REPORT
}

\author{
OFFICE OF THE DELAWARE RIVER MASTER \\ United States Geological Survey \\ 415 National Center \\ Reston, Virginia 20192
}

October 12, 2011

The Honorable

John G. Roberts, Jr.

Chief Justice of the United States

The Honorable

Jack A. Markell

Governor of Delaware

The Honorable

Christopher J. Christie

Governor of New Jersey

The Honorable

Andrew M. Cuomo

Governor of New York

The Honorable

Tom Corbett

Governor of Pennsylvania

The Honorable

Michael R. Bloomberg

Mayor of the City of New York

No. 5, Original.-October Term, 1950

State of New Jersey, Complainant, $v$

State of New York and City of New York, Defendants, Commonwealth of Pennsylvania and State of Delaware, Intervenors.

Dear Sirs:

For the record, and in compliance with the provisions of the Amended Decree of the Supreme Court of the United States entered June 7, 1954, I am hereby transmitting the 53rd Annual Report of the River Master of the Delaware River for the 12-month period from December 1, 2005, to November 30, 2006. In this report, this period is referred to as the River Master report year or the report year.

During the 2006 River Master report year, monthly precipitation in the upper Delaware River Basin ranged from 39 percent of the long-term average in March 2006 to 290 percent of the long-term average in June 2006. Total precipitation during the report year was 11.36 inches (in.) more than the long-term average. Precipitation during the December to May period, when reservoirs typically refill, was 1.08 in. 
less than the 65-year average. Precipitation during the report year was below normal in December, February, March, July, and August, and above normal in the other seven months.

On December 1, 2005, when the report year began, combined storage in the New York City reservoirs in the upper Delaware River Basin was 213.173 billion gallons (Bgal) or 78.7 percent of combined storage capacity. Median combined storage on December 1, computed on the basis of 38 years of record, is 177.307 Bgal. In early February, the Decree Parties established temporary spill reduction programs for Pepacton and Neversink Reservoirs. Storage remained above median levels throughout the year. During the report year, operations in the basin were conducted as stipulated by the Decree.

On April 27, 2006, the Delaware River Master Advisory Committee met at the U.S. Geological Survey's (USGS) New Jersey Water Science Center in West Trenton, New Jersey, to discuss hydrologic conditions in the basin and operational procedures for the 2006 reservoir-release season. During the report year, the following individuals served as members of the Advisory Committee:

$\begin{array}{ll}\text { Delaware } & \text { John H. Talley } \\ \text { New Jersey } & \text { Samuel A. Wolfe } \\ \text { New York } & \text { Sandra Allen } \\ \text { New York City } & \text { Michael A. Principe } \\ \text { Pennsylvania } & \text { Cathleen Curran Myers }\end{array}$

The River Master informed the Advisory Committee that, on the basis of information provided by New York City, the excess-release quantity beginning June 15, 2006, was 8.763 Bgal. Based on reservoir release programs in Delaware River Basin Commission (DRBC) Docket No. D-77-20 CP (Revisions Nos. 7 and 8), the excess-release quantity was to be used for various purposes. In late September, the Decree Parties established a temporary spill reduction program described in DRBC Docket No. D-77-20-CP (Revision 9) for Pepacton, Cannonsville, and Neversink Reservoirs.

During the report year, the River Master and staff participated in a number of water-supply related meetings of the DRBC. The Deputy Delaware River Master met periodically with representatives of the Decree Parties as a member of the Decree Parties Work Group and DRBC's Regulated Flow Advisory Committee. Issues of particular interest to the River Master involved management of reservoir releases and regulated streamflow in the upper Delaware River Basin.

The USGS continued operation of its field office of the Delaware River Master at Milford, Pennsylvania. Gary N. Paulachok, Deputy Delaware River Master, continued in charge of the office, assisted by Bruce E. Krejmas, Hydrologist.

During the year, the River Master's office continued the weekly distribution of a summary hydrologic report. These reports contain provisional data on precipitation in the upper Delaware River Basin, releases and spills from New York City reservoirs to the Delaware River, diversions to the New York City watersupply system, reservoir contents, daily segregation of flow of the Delaware River at the USGS Montague, New Jersey gaging station, and diversions by New Jersey. The reports were distributed to members of the Delaware River Master Advisory Committee and to other parties interested in Delaware River operations. A monthly summary of hydrologic conditions also was provided to Advisory Committee members. The weekly and monthly hydrologic reports were posted on the River Master's Web site. 
The first section of this report documents Delaware River operations during the report year. During the year, the City of New York diverted 138.091 Bgal from the Delaware River Basin and released 135.791 Bgal from Pepacton, Cannonsville, and Neversink Reservoirs to the Delaware River. The River Master directed releases from these reservoirs to the Delaware River that totaled 14.248 Bgal.

The second section of this report describes water quality at various monitor sites on the Delaware Estuary. It includes basic data on chemical properties and physical characteristics of the water, and presents summary statistics on the data.

Throughout the year, diversions to New York City's water supply and releases designed to maintain the flow of the Delaware River at Montague were made as directed by the River Master. Diversions by New York City from its reservoirs in the Delaware River Basin did not exceed the limit stipulated by the Decree. Diversions by New Jersey also were within stipulated limits.

The River Master and staff are grateful for the continued cooperation and support of the Decree Parties. Also, the contributions of the PPL Corporation and Mirant Corporation in informing the River Master of plans for power generation and furnishing data on reservoir releases are greatly appreciated.

Sincerely yours,

/Signed/

Stephen F. Blanchard

Delaware River Master 


\section{DELAWARE RIVER OPERATIONS}

\section{Abstract}

A Decree of the Supreme Court of the United States, entered June 7, 1954, established the position of Delaware River Master within the U.S. Geological Survey (USGS). In addition, the Decree authorizes diversions of water from the Delaware River Basin and requires compensating releases from certain reservoirs, owned by New York City, to be made under the supervision and direction of the River Master. The Decree stipulates that the River Master will furnish reports to the Court, not less frequently than annually. This report is the 53rd Annual Report of the River Master of the Delaware River. It covers the 2006 River Master report year-the period from December 1, 2005, to November 30, 2006.

During the report year, precipitation in the upper Delaware River Basin was 55.03 inches (in.) or 126 percent of the long-term average. Combined storage in Pepacton, Cannonsville, and Neversink Reservoirs was above the long-term median level on December 1, 2005. Reservoir storage remained above longterm median levels throughout the report year. Delaware River operations during the year were conducted as stipulated by the Decree.

Diversions from the Delaware River Basin by New York City and New Jersey were in full compliance with the Decree. Reservoir releases were made as directed by the River Master at rates designed to meet the flow objective for the Delaware River at Montague, New Jersey, on 27 days during the report year. Releases were made at conservation rates-or rates designed to relieve thermal stress and protect the fishery and aquatic habitat in the tailwaters of the reservoirs - on all other days.

During the report year, New York City and New Jersey complied fully with the terms of the Decree, and directives and requests of the River Master.

As part of a long-term program, the quality of water in the Delaware Estuary between Trenton, New Jersey, and Reedy Island Jetty, Delaware, was monitored at various locations. Data on water temperature, specific conductance, dissolved oxygen, and $\mathrm{pH}$ were collected continuously by electronic instruments at four sites. In addition, selected water-quality data were collected at 19 sites on a twice-monthly basis and at 3 sites on a monthly basis.

\section{Introduction}

An Amended Decree of the Supreme Court of the United States, entered June 7, 1954, authorized diversions of water from the Delaware River Basin and provided for releases of water from three New York City reservoirs-Pepacton, Cannonsville, and Neversink - to the upper Delaware River. The Decree stipulates that these diversions and releases are to be made under the supervision and direction of the Delaware River Master. The Decree also stipulates that reports on Delaware River operations be made to the Court not less frequently than annually. This report documents operations from December 1, 2005, to November 30, 2006, or the 2006 River Master report year. The report also presents information on the quality of water in the Delaware Estuary during the report year.

Some hydrologic data presented in this report are records of streamflow and water quality for USGS data-collection stations. These records were collected, computed, and furnished by the offices of the 
USGS at Troy, New York; Exton and New Cumberland, Pennsylvania; and West Trenton, New Jersey, in cooperation with the States of New York and New Jersey, the Commonwealth of Pennsylvania, and the City of New York. The locations of major streams and reservoirs, and selected streamflow-gaging stations in the Delaware River Basin are shown in figure 1.

\section{Acknowledgments}

The River Master's daily operation records were prepared from hydrologic data collected chiefly on a day-to-day basis. Data for these records were collected and computed by the Office of the Delaware River Master or were furnished by the following agencies and utilities: Data for Pepacton, Cannonsville, and Neversink Reservoirs by the New York City Department of Environmental Protection, Bureau of Water Supply; for Lake Wallenpaupack by the PPL Corporation; and for Rio Reservoir by Mirant Corporation. Precipitation data and quantitative precipitation forecasts were provided by the National Weather Service (NWS) office in Binghamton, New York.

\section{Definition of Terms and Procedures}

The following definitions apply to various terms and procedures used in the operations documented in this report. A table for converting inch-pound units to the International System of Units (SI) is given on page vi.

- Balancing Adjustment.-An operating procedure used by the River Master to correct for inaccuracies inherent in the design of releases from New York City reservoirs to meet the Montague flow objective. The balancing adjustment is computed as 10 percent of the difference between the cumulative adjusted directed release and the cumulative directed release required for exact forecasting. The balancing adjustment is applied to the following day's release design. The maximum daily balancing adjustment is intentionally limited to preclude unacceptably large variations in the adjusted flow objective.

- Capacity.-Total usable volume in a reservoir between the point of maximum depletion and the elevation of the lowest crest of the spillway.

- Conservation releases.-Controlled releases from Pepacton, Cannonsville, and Neversink Reservoirs designed to maintain specified minimum flows in stream channels (tailwaters) below the reservoirs. The conservation rates shown in table $2^{1}$ are defined as follows:

- Normal.-Conservation releases when New York City combined reservoir storage is in the normal operations zone.

- Watch.-Conservation releases when New York City combined reservoir storage is in the drought watch operations zone.

- Warning.-Conservation releases when New York City combined reservoir storage is in the drought warning operations zone.

- Drought.-Conservation releases when New York City combined reservoir storage is in the drought operations zone.

The combined storage zones for New York City Delaware Basin reservoirs are shown in figure 2.

${ }^{1}$ All numbered tables in the section "Delaware River Operations" are grouped at the end of this section, beginning on page 23. 


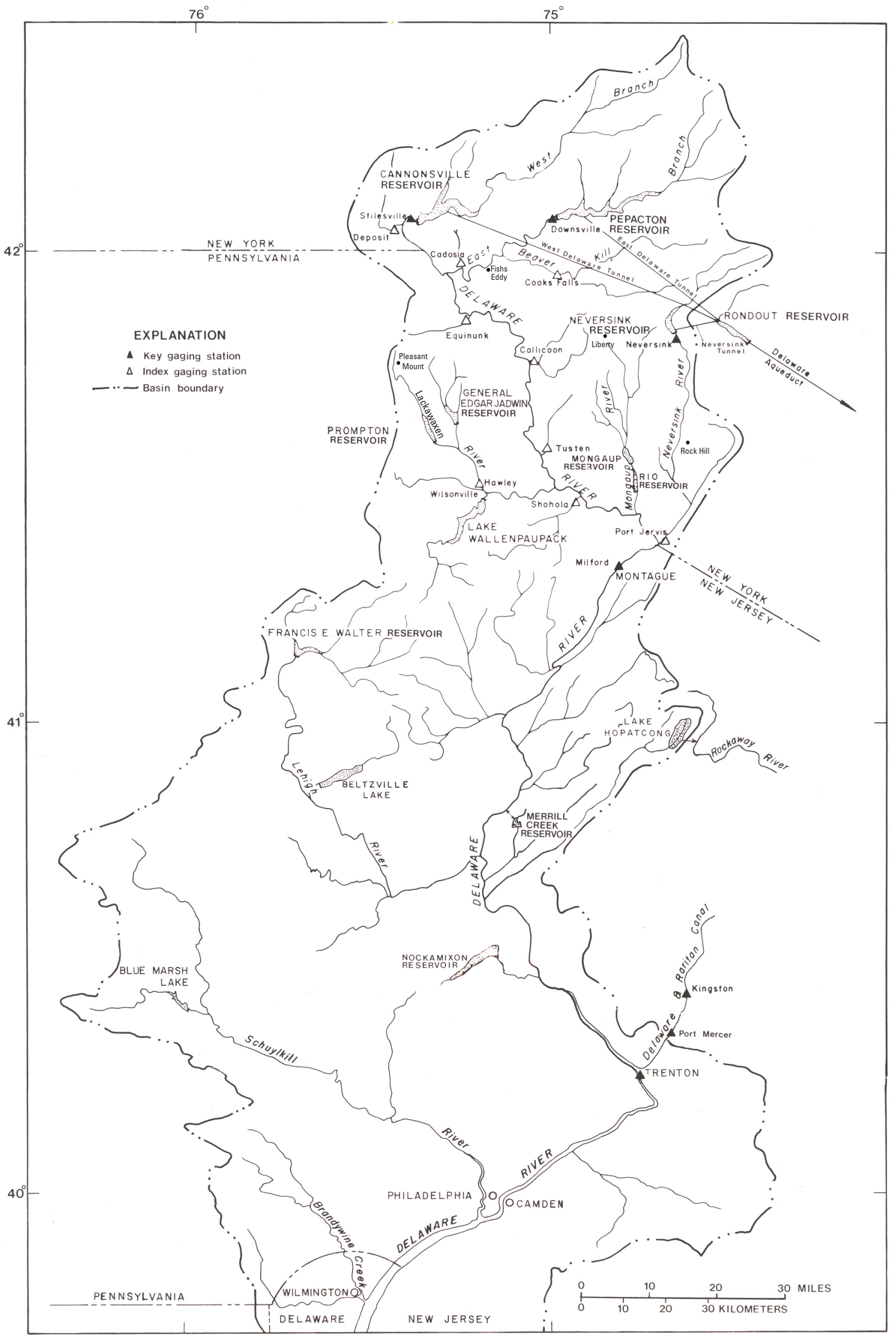

Figure 1. Delaware River Basin above Wilmington, Delaware. 


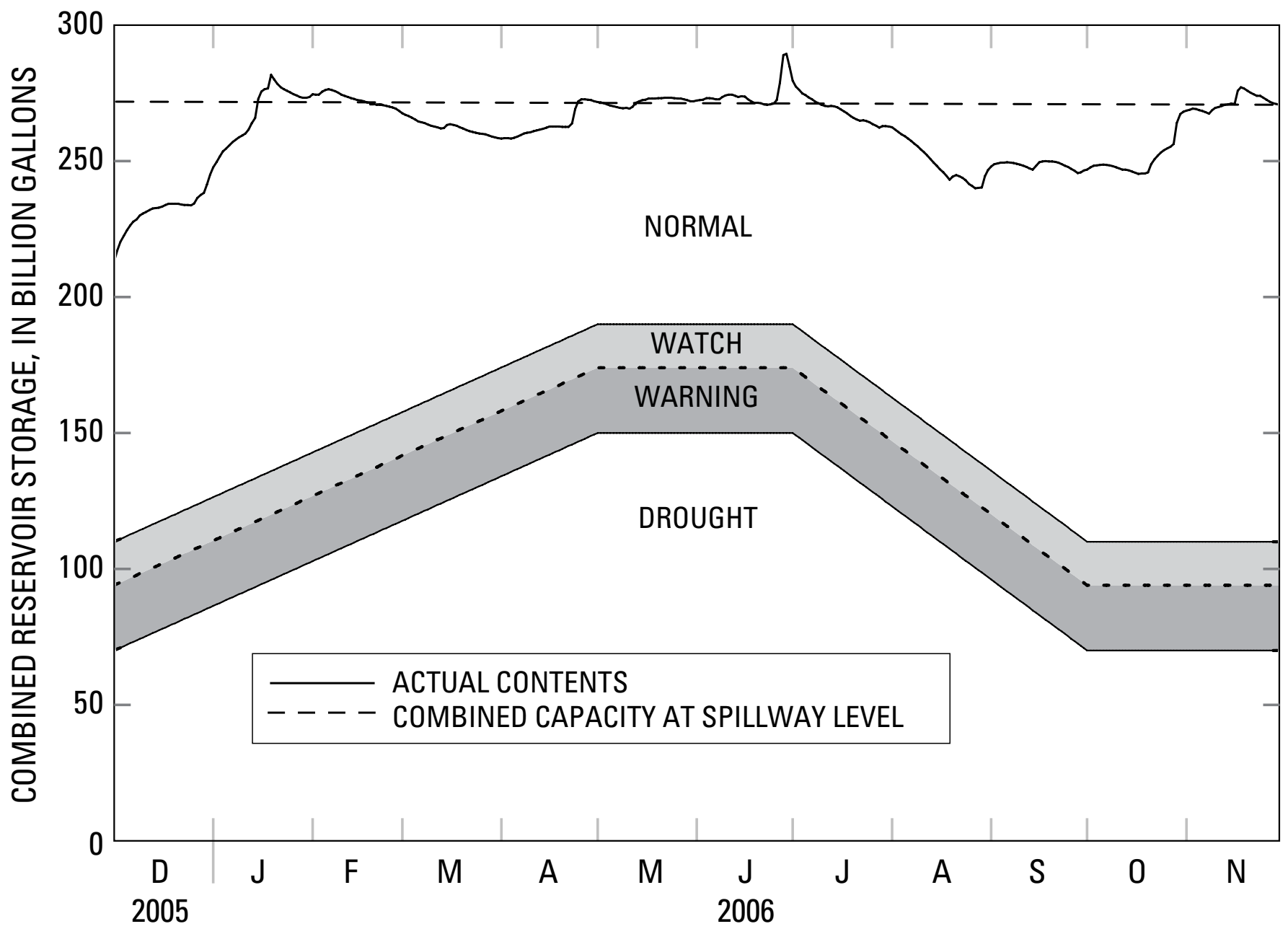

Figure 2. Operation curves and actual contents for New York City reservoirs in the Delaware River Basin, December 1, 2005, to November 30, 2006.

- Daily excess-release credits.-Daily credits and deficits during the seasonal release period (June 15 to the following March 15) are computed as the arithmetic difference between the daily mean discharge of the Delaware River at Montague, New Jersey, and 1,750 cubic feet per second ( $\left.\mathrm{ft}^{3} / \mathrm{s}\right)$. The daily credit cannot exceed the 24-hour period releases from Pepacton, Cannonsville, and Neversink Reservoirs routed to Montague and made in accordance with direction, except as follows: during the seasonal period, credits also are applied for part or all of other releases from these reservoirs that contribute to the daily mean discharge at Montague between 1,750 $\mathrm{ft}^{3} / \mathrm{s}$ and the applicable excessrelease rate.

- Directed releases.-Controlled releases from New York City reservoirs in the upper Delaware River Basin, designed by the Delaware River Master to meet the Montague flow objective.

- Diversions.- The out-of-basin transfer of water by New York City from Pepacton, Cannonsville, and Neversink Reservoirs in the upper Delaware River Basin through the East Delaware, West Delaware, and Neversink Tunnels, respectively, to the City's water-supply system. Also, the out-of-basin transfer of water by New Jersey from the Delaware River through the Delaware and Raritan Canal.

- Excess quantity.-As defined by the Decree, the excess quantity of water is equal to 83 percent of the amount by which the estimated consumption in New York City during the year is less than the City's estimate of continuous safe yield [1,665 million gallons per day (Mgal/d) stipulated by 
the 1954 Decree] from all its sources of supply obtainable without pumping, except that the excess quantity shall not exceed 70 Bgal. Each year, the seasonal period for release of the excess quantity begins on June 15. The flow objective for the period becomes effective at Montague on that date and remains in effect until the following March 15, or until the cumulative total of excess-release credits equals the applicable excess quantity, whichever occurs first.

- Index gaging stations. - Particular sites on tributaries of the upper Delaware River where systematic observations of gage height and discharge are made. These stations are used mainly during the directed-release season to estimate inflows of surface water to the upper Delaware River.

- Key gaging stations.-Particular sites on the East Branch Delaware River, West Branch Delaware River, Neversink River, Delaware and Raritan Canal, and mainstem Delaware River where continuous, systematic observations of gage height and discharge are made. These stations are used on a year-round basis in River Master operations.

- Maximum reservoir depletion.-The minimum water-surface level or elevation below which a reservoir ceases to continue making delivery of quantities of water for all purposes for which the reservoir was designed. This also is referred to as minimum full-operating level.

- Rate of flow.-Mean discharge for a specified 24-hour period, in cubic feet per second or million gallons per day.

- Rate of flow at Montague.-Daily mean discharge of the Delaware River at Montague, New Jersey, computed on a calendar-day basis.

- Reservoir-controlled releases.-Controlled releases from reservoirs passed through outlet valves in the dams or through turbines in powerplants. These releases do not include spillway overflow at the reservoirs.

- Storage or contents. - Usable volume of water in a reservoir. Unless otherwise indicated, volume is computed on the basis of level pool and above the point of maximum depletion.

- Time of day.- - Time of day is expressed in 24-hour Eastern Standard Time, which during the report year included a 23-hour day on April 2 and a 25-hour day on October 29.

- Uncontrolled runoff at Montague.-Runoff from the 3,480 square mile $\left(\mathrm{mi}^{2}\right)$ drainage area above Montague, New Jersey, excluding the drainage area above Pepacton, Cannonsville, Neversink, Wallenpaupack, and Rio Dams, but including spillway overflow at these dams.

\section{Precipitation}

Precipitation in the Delaware River Basin above Montague, New Jersey, totaled 55.03 in. during the 2006 report year and was 11.36 in. greater than, or 126 percent of, the long-term (65-year) average. Monthly precipitation ranged from 39 percent of the long-term average in March 2006 to 290 percent of average in June 2006. Data on monthly precipitation during the report year and long-term average precipitation are presented in table $1^{1}$. These data were computed from records collected at 10 geographically distributed stations by the NWS; the New York City Department of Environmental Protection, Bureau of Water Supply; and the River Master office.

\footnotetext{
${ }^{1}$ All numbered tables in the section "Delaware River Operations" are grouped at the end of this section, beginning on page 23.
} 
The seasonal period from December to May typically is when surface-water and groundwater reservoirs refill. During this period in 2005-2006, total precipitation was 19.26 in., which is 95 percent of the 65-year average. During June to November, total precipitation was 35.77 in., which is 153 percent of the long-term average. The maximum monthly precipitation was 11.62 in. in June 2006, measured at Fishs Eddy, New York; the minimum monthly precipitation was 1.32 in. in March 2006, measured at Neversink, New York (locations shown on fig. 1).

\section{Operations}

\section{December to May}

Operations on December 1, 2005, were conducted as prescribed by the Decree. The Montague flow objective was 1,750 ft $3 / \mathrm{s}$, and the allowable diversions to New York City and New Jersey were $800 \mathrm{Mgal} / \mathrm{d}$ and $100 \mathrm{Mgal} / \mathrm{d}$, respectively. Conservation releases from New York City reservoirs were made at the rates shown in table 2, which are incorporated in Delaware River Basin Commission (DRBC) Docket D-77-20 CP (Revision 7).

From December 2005 to May 2006, the first half of the report year, total precipitation was 1.06 in. below average. Monthly precipitation ranged from 39 percent of the long-term average in March 2006 to 172 percent in January 2006 (table 1). Runoff in the upper basin was above normal in January and February, normal in December and May, and below normal in March and April.

On December 1, 2005, when the 2006 report year began, Pepacton Reservoir contained 114.728 Bgal of water in storage above the point of maximum depletion, or 81.8 percent of the 140.190 Bgal storage capacity. Cannonsville Reservoir contained $66.974 \mathrm{Bgal}$, or 70.0 percent of the $95.706 \mathrm{Bgal}$ storage capacity. Neversink Reservoir contained 31.471 Bgal, or 90.1 percent of the 34.941 Bgal storage capacity. Combined storage in these reservoirs on December 1, 2005, was 213.173 Bgal, or 78.7 percent of combined capacity. Daily storage in Pepacton, Cannonsville, and Neversink Reservoirs is given in tables 3, 4, and 5 , respectively, and combined storage during the report year is shown in figure 2 .

The Decree Parties continued an experimental augmented conservation releases program for the New York City Delaware Basin Reservoirs that began on May 1, 2004. This program established a habitat protection bank, which consisted of an excess release quantity bank, a thermal protection bank, and a supplemental release bank. It also established flow targets for all three tailwaters at certain USGS gaging stations downstream of the reservoirs.

On February 8, 2006, in consideration of hydrologic conditions resulting in high storage levels in Pepacton and Neversink Reservoirs, the Decree Parties implemented a temporary spill reduction program. This program attempted to manage a storage void to completely capture runoff from a 1-inch rainfall event and to reduce or eliminate spills through the use of preemptive controlled releases. This temporary program ran concurrently with the snowpack-based spill reduction program implemented in 2004. The agreements for the temporary spill reduction program are presented in Appendix A for Pepacton Reservoir and in Appendix B for Neversink Reservoir.

From December to May, inflow to the City's reservoirs typically exceeds outflow and, consequently, storage increases. The average inflow to Pepacton, Cannonsville, and Neversink Reservoirs for this 
6-month period, computed on the basis of the 65-year period from December 1940 to May 2005, was 302.3 Bgal. During the corresponding 6 months of the report year, inflow to the three reservoirs totaled 289.7 Bgal. Evaporation loss is not included in the computations.

Combined storage increased steadily from December 2005 to mid-January 2006, when the reservoirs filled. Combined storage remained high during winter, then increased to full capacity in late April. The combined storage of the reservoirs was about 100 percent of capacity on May 31, 2006.

Combined storage in the three New York City reservoirs was 206.391 Bgal on November 30, 2005, and 271.950 Bgal on May 31, 2006, a net increase of 65.559 Bgal or 24.2 percent of total capacity. The maximum combined storage during the December to May period was 281.750 Bgal on January 19, 2006. Maximum storage in Pepacton Reservoir during the December to May period was 144.060 Bgal on January 19; maximum storage in Cannonsville Reservoir was 102.192 Bgal on January 19; and maximum storage in Neversink Reservoir was 35.498 Bgal on January 19, 2006. Pepacton Reservoir spilled from January 15 to February 14, April 24 to May 4, and May 13-31. Cannonsville Reservoir spilled from January 9 to May 31. Neversink Reservoir spilled from January 15 to February 11 and May 14-26. The combined spill volume from the three reservoirs during this period was $138.063 \mathrm{Bgal}$.

During the December to May period, diversions to Rondout Reservoir by New York City totaled $59.191 \mathrm{Bgal}(325 \mathrm{Mgal} / \mathrm{d})$. The forecasted discharge at Montague, exclusive of water released from the City reservoirs, was greater than the flow objective on all days within the period, and no releases were directed. The observed daily mean discharge at Montague was greater than the applicable flow objective on all days. Applicable design rates for the USGS gaging station Delaware River at Montague, New Jersey, are presented in table 6.

\section{June to November}

Monthly precipitation for the June to November period was above average in June, September, October, and November and below average in July and August. Total precipitation during the period was 35.77 in. or 12.45 in. more than the 65 -year average (table 1 ).

Combined storage in the three New York City reservoirs was 272.330 Bgal on June 1, 2006, and 270.643 Bgal on November 30, 2006, a net decrease of 1.687 Bgal or about 0.6 percent of total capacity. During the June to November period, maximum storage in Pepacton Reservoir was 145.717 Bgal on June 28; 108.873 Bgal in Cannonsville Reservoir on June 29; and 35.778 Bgal in Neversink Reservoir on June 28. Maximum combined storage in the three reservoirs was 289.426 Bgal on June 29, 2006. The combined spill volume from the three reservoirs during this period was $171.073 \mathrm{Bgal}$.

Releases were directed to meet the Montague flow objective on 27 days between June 1 and November 30, 2006, when the forecasted discharge at Montague, exclusive of water released from the New York City reservoirs, was less than the flow objective. Releases at rates designed to protect the fishery and aquatic habitat were made at other times during the period.

From June 1 to June 14, the Montague flow objective was $1,750 \mathrm{ft}^{3} / \mathrm{s}$. The forecasted flow, exclusive of releases from Pepacton, Cannonsville, and Neversink Reservoirs, did not fall below the flow objective and no releases were directed. 
The New York City Department of Environmental Protection, Bureau of Water Supply, Quality, and Protection furnished the River Master with the following data for the 2006 calendar year, as stipulated by the Decree:

1. The estimated continuous safe yield from all the City's sources, obtainable without pumping, is $1,665 \mathrm{Mgal} / \mathrm{d}$, or a total during calendar year 2006 of $1.665 \mathrm{Bgal} / \mathrm{d}$ x 365 days $=607.725 \mathrm{Bgal}$.

2. The estimated consumption that the City must provide for, from all its sources of supply during calendar year 2006, is $591.582+7.250=598.832$ Bgal .

On the basis of the Decree and the above-noted data, the aggregate quantity of excess-release water was 83 percent of (607.725 - 598.832), or 7.381 Bgal.

Data on water consumption by the City of New York for each calendar year since 1950, from all sources of supply, are presented in table 7.

As part of the reservoir releases program stipulated in DRBC Docket No. D-77-20 CP (Revision No. 7), about 42 percent of the annual excess-release quantity was placed in a habitat protection bank. The remainder of the excess-release quantity could be used to provide an increase in the Montague flow objective or could be banked in accordance with the procedures given in the DRBC's Lower Basin Drought Management Plan.

On June 15, 2006, the beginning of the seasonal excess-release period, the Montague flow objective was increased to $1,800 \mathrm{ft}^{3} / \mathrm{s}$. Storage in the New York City reservoirs declined slowly from July to August, remained steady from September to mid-October, then increased to nearly full or full levels from late October to the end of the report year.

Excessive rainfall of more than 7 in. over a 3-day period in late June 2006 resulted in a major flood in the Delaware River Basin. The USGS Delaware River at Montague, New Jersey streamflow gaging station recorded a peak stage of $32.15 \mathrm{ft}$ on June 29, 2006, corresponding to a discharge of 212,000 $\mathrm{ft}^{3} / \mathrm{s}$.

On September 21, 2006, the Decree Parties implemented a new temporary spill mitigation program for Neversink, Pepacton, and Cannonsville Reservoirs. The interim programs for Pepacton and Neversink Reservoirs, effective November 1, 2005, and the rainfall event based temporary spill reduction programs for Pepacton and Neversink Reservoirs, effective February 8, 2006, were suspended for the duration of the new program. The program, DRBC Docket No. D-77-20-CP (Revision 9) expired on May 31, 2007 and is presented in Appendix C.

From June 15 to November 30, 2006, the forecasted flow at Montague, exclusive of releases from the New York City reservoirs, was less than the flow objective on 27 days and releases were directed by the River Master. On 4 days during the June 15 to November 30 period, the observed flow was less than the flow objective. On 3 of these 4 days, observed flows were within 10 percent of the flow objective. Applicable design rates for the USGS gaging station Delaware River at Montague, New Jersey, are presented in table 6 .

The total discharge observed at Montague, the portion derived from uncontrolled runoff from the drainage area below the reservoirs, the portion contributed by power reservoirs, and the portion contrib- 
uted by Pepacton, Cannonsville, and Neversink Reservoirs during August 2006 are shown in figure 3. In developing the water budget for Montague, uncontrolled runoff was computed as the residual of observed flow minus releases and spills from all reservoirs, and, consequently, was subject to errors in observations, transit times, and routing of the various components of flow. The conservation release from Rio Reservoir is included in the uncontrolled runoff component. The net effect of these uncertainties is incorporated in the computation of uncontrolled runoff. From June 1 to November 30, 2006, diversions from the three New York City Delaware Basin reservoirs to Rondout Reservoir totaled 78.900 Bgal.

\section{Summary of Operations}

From December 1, 2005 to November 30, 2006, diversions from the three New York City reservoirs in the upper Delaware River Basin to Rondout Reservoir totaled 138.091 Bgal, and all releases from the three reservoirs to the Delaware River totaled 135.791 Bgal. River Master directed releases to the Delaware River from these reservoirs totaled 14.248 Bgal.

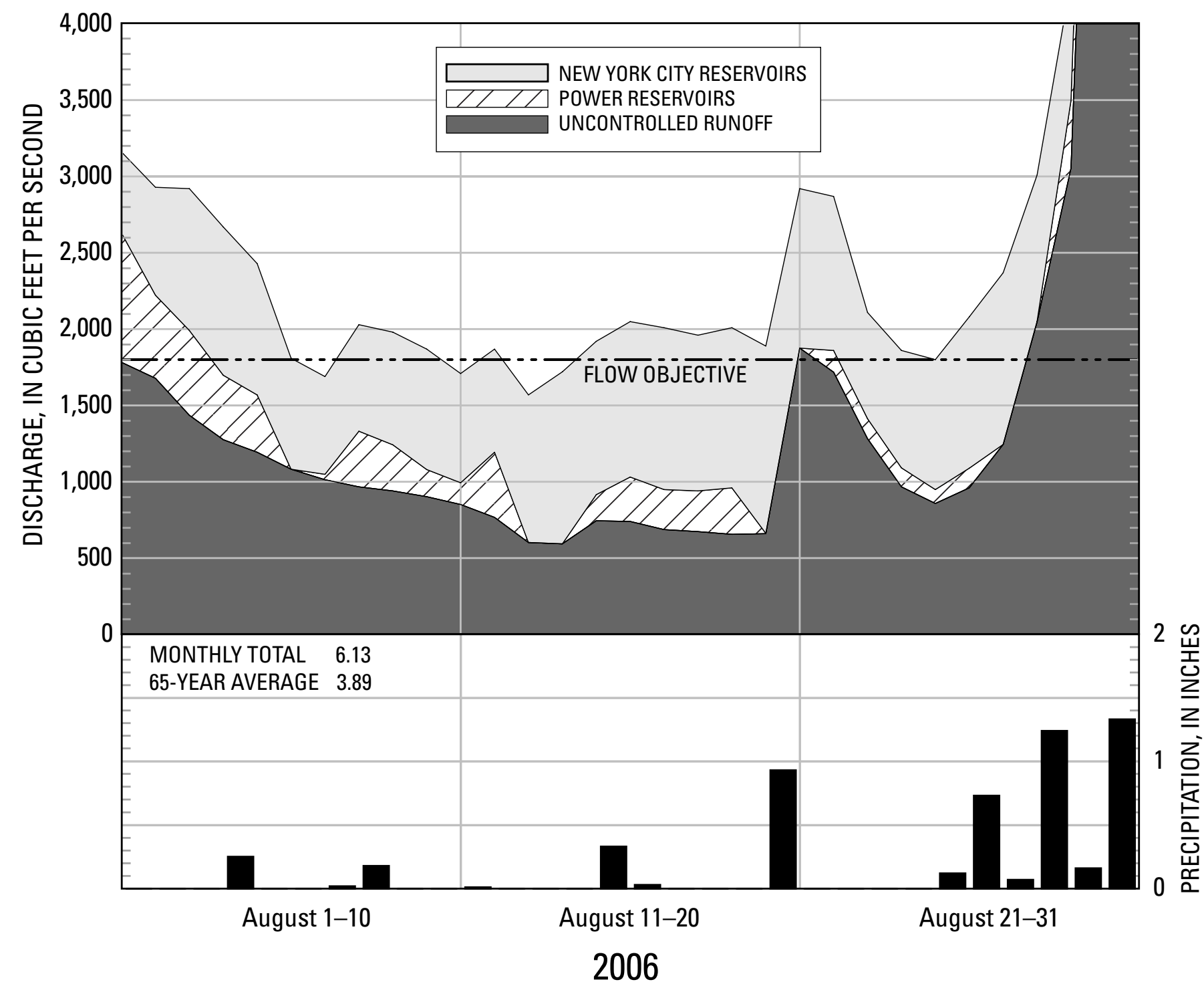

Figure 3. Components of flow, Delaware River at Montague, New Jersey, August 2006. 
During the year, maximum storage in Pepacton Reservoir was 145.717 Bgal (103.9 percent of capacity) on June 28, 2006; 108.873 Bgal (113.8 percent of capacity) in Cannonsville Reservoir on June 29; and 35.778 Bgal (102.4 percent of capacity) in Neversink Reservoir on June 28. Maximum combined storage in the three reservoirs was $289.426 \mathrm{Bgal}$ (106.9 percent of combined capacity) on June 29, 2006. The combined spill volume from the three reservoirs for the report year was $309.136 \mathrm{Bgal}$.

During the report year, minimum storage in Pepacton Reservoir was 114.728 Bgal (81.8 percent of capacity) on December 1, 2005; 66.974 Bgal (70.0 percent of capacity) in Cannonsville Reservoir on December 1, 2005; and 22.709 Bgal (65.0 percent of capacity) in Neversink Reservoir on August 29, 2006. Minimum combined storage in the three reservoirs was $213.173 \mathrm{Bgal}$ (78.7 percent of combined capacity) on December 1, 2005.

On November 30, 2006, the end of the report year, combined storage in the three reservoirs was 270.643 Bgal or 99.9 percent of combined capacity. From December 1, 2005 to November 30, 2006, the net change in combined storage was $+57.470 \mathrm{Bgal}$, or an increase equivalent to 21.2 percent of combined capacity.

Combined storage for the three reservoirs on the first day of the month was above median in all months of the report year (fig. 4). A new record-high combined storage level for the first day of the month was set in February 2006.

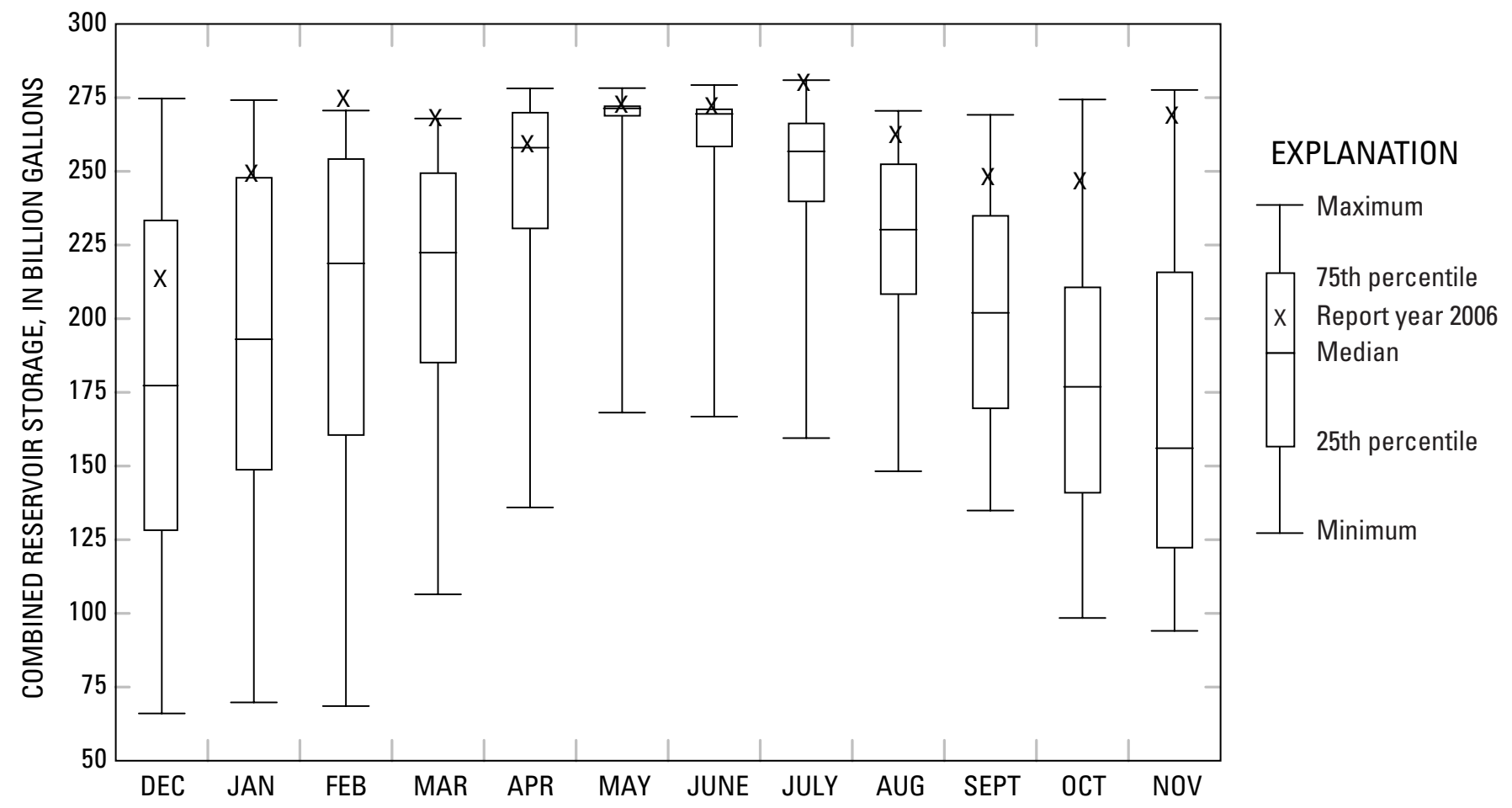

Figure 4. Combined storage in Pepacton, Cannonsville, and Neversink Reservoirs on the first day of the month, December 2005 to November 2006 (this report year), and summary statistics for the reference period, June 1967 to November 2005. 


\section{Streamflow}

\section{Components of Flow, Delaware River at Montague, New Jersey}

The data and computations of the various components of flow form the basic operational records used by the River Master to carry out specific responsibilities related to the Montague formula. The operational record has two parts: forecasted flow at Montague, exclusive of controlled releases from New York City's reservoirs (table 8), and segregation of components of daily mean flow at Montague (table 9).

The following components may be present in the flow of the Delaware River at Montague:

1. Controlled releases from Lake Wallenpaupack on Wallenpaupack Creek, for the production of hydroelectric power.

2. Controlled releases from Rio Reservoir on Mongaup River, for the production of hydroelectric power.

3. Runoff from the uncontrolled area above Montague, including spills from New York City reservoirs, Lake Wallenpaupack, and Rio Reservoir.

4. Controlled releases from Pepacton, Cannonsville, and Neversink Reservoirs of New York City.

The releases from New York City's reservoirs necessary to meet the Montague flow objective were computed on the basis of the forecasted flow at Montague, exclusive of controlled releases from the reservoirs.

\section{Time of Travel}

Following are average times for the effective travel of water from the various sources of controlled supply to Montague, New Jersey. These times were used for flow routing during the 2006 report year.

\begin{tabular}{lc}
\hline \multicolumn{1}{c}{ Source } & $\begin{array}{c}\text { Travel time, } \\
\text { in hours }\end{array}$ \\
\hline Pepacton Reservoir & 60 \\
Cannonsville Reservoir & 48 \\
Neversink Reservoir & 33 \\
Lake Wallenpaupack & 16 \\
Rio Reservoir & 8 \\
\hline
\end{tabular}

Travel times were computed from reservoir and powerplant operations data and historical streamflow records. The travel times generally are suitable for use in the operations of the River Master. Occasionally, however, significant exceptions are observed. For example, when a large release from Cannonsville Reservoir follows a small release, a substantial portion of the water fills the channel en route, and the remainder may arrive at Montague as much as 66 hours after the time of release. During winter, the formation of ice, together with lower streamflow, gradually increases the resistance to water flow, resulting in increased travel times. Because ice-affected travel times increase gradually over several days, and releases were not 
directed to meet the Montague flow objective during periods of ice, no adjustments were made to compensate for increased travel times during these periods of the report year.

\section{Segregation of Flow at Montague}

The River Master daily operations record of reservoir releases and segregation of the various components contributing to the flow of the Delaware River at Montague, New Jersey, are presented in table 9. The data are arranged to conform to the downstream movement of water from the various sources to Montague. Summation of data across individual rows in the table is equivalent to routing the various flow contributions to Montague, using the above-noted average travel times. Uncontrolled runoff was computed as a residual by subtracting the flow contributions of all other sources from the observed discharge at Montague.

\section{Computation of Directed Releases}

During the report year, the River Master used the following information for daily operations: (1) discharges computed from recorded or reported stream gage heights, for various 24-hour periods, absent real-time information on any changes in stage-discharge relations; (2) daily discharge from New York City's three Delaware Basin reservoirs, measured with venturi meters; (3) precipitation reports for the previous 24 hours; (4) actual powerplant releases converted to daily discharges; (5) advance estimates of power demand converted to daily discharges; (6) advance estimates of uncontrolled runoff at Montague; and (7) average travel times for routing water from various sources. Although uncertainty is inherent in the advance estimates, this information is used by necessity in the daily design and direction of reservoir releases.

The 60-hour travel time of water from Pepacton Reservoir to Montague is greater than the travel time of water from any other reservoir in the upper Delaware River Basin. Releases from Cannonsville and Neversink Reservoirs were timed to arrive at Montague concurrently with releases from Pepacton Reservoir. To allow for differences in travel times, daily directed releases were scheduled to begin from Pepacton Reservoir at 1200 hours, from Cannonsville Reservoir at 2400 hours, and from Neversink Reservoir at 1500 hours the following day.

Releases from the City's reservoirs required to meet the Montague flow objective were computed from forecasts of releases from Lake Wallenpaupack and Rio Reservoir, and estimates of uncontrolled runoff at Montague. To account for the travel times from these sources to Montague, the computation requires estimates of the following components of flow two or more days in advance: (1) release of water from Lake Wallenpaupack; (2) release of water from Rio Reservoir; and (3) uncontrolled runoff from the drainage area upstream of Montague. The River Master operations record for computing daily directed release requirements during periods of low flow is given in table 8 .

The electric utilities furnished forecasts of power generation and releases. Because the hydroelectric plants were used chiefly for area regulation or meeting peak power demands, the forecasts were subject to various modifying factors, including the vagaries of weather on electricity demand. In addition, because the power companies are members of regional transmission organizations, demand for power outside of the local service area may unexpectedly affect generation schedules. Consequently, at times, the actual use of water for power generation differs considerably from the forecasts used in the design of reservoir releases. 
For computational purposes during periods of low flow, estimates of uncontrolled runoff at Montague were treated as two components: (1) current runoff and (2) forecasted increase in runoff from precipitation. Estimates of these components are given in table 8.

During ice-free conditions, current runoff was computed using a routing and recession procedure based on discharges at 0800 hours at the following USGS gaging stations:

\begin{tabular}{lc}
\hline \multicolumn{1}{c}{ Station Name } & $\begin{array}{c}\text { Drainage Area } \\
\left(\mathbf{m i}^{\mathbf{2}} \mathbf{)}\right.\end{array}$ \\
\hline Beaver Kill at Cooks Falls, New York & 241 \\
Oquaga Creek at Deposit, New York & 67.6 \\
Equinunk Creek at Equinunk, Pennsylvania & 56.3 \\
Callicoon Creek at Callicoon, New York & 110 \\
Tenmile River at Tusten, New York & 45.6 \\
Lackawaxen River at Hawley, Pennsylvania & 290 \\
Shohola Creek near Shohola, Pennsylvania & 83.6 \\
Neversink River at Port Jervis, New York & 336 \\
\hline
\end{tabular}

During winter, the advance estimate of uncontrolled runoff (current conditions) was made on the basis of observed flows at a reduced network of gaging stations and the recession curve for computed uncontrolled flow at Montague.

The forecasted runoff from precipitation is shown in table 8 under the heading "Weather Adjustment." Throughout the year, the NWS office in Binghamton, New York, furnished quantitative forecasts of average precipitation and air temperatures for the 3,480- $\mathrm{mi}^{2}$ drainage basin upstream of Montague, New Jersey. During winter, runoff was estimated on the basis of the current status of snow and ice, along with forecasted precipitation and temperature. During other periods, forecasted precipitation was used to estimate runoff.

The forecasted flow at Montague, exclusive of releases from New York City's Delaware Basin reservoirs (table 8), is computed as the sum of forecasted releases from power reservoirs, estimated uncontrolled runoff including conservation releases from Rio Reservoir, and weather adjustments. If the computed total flow is less than the flow objective at Montague, then the deficiency is made up by releases from the City's reservoirs, as directed by the River Master.

When forecasts of precipitation or powerplant releases were revised appreciably after a release was directed, the release required from the City's reservoirs was recomputed. Commonly, this procedure resulted in a reduced release requirement for New York City reservoirs for that day. Only final figures for releases from New York City reservoirs are given in table 8.

\section{Analysis of Forecasts}

Forecasts of streamflow at Montague, developed on the basis of anticipated contributions from the components described previously but excluding releases from New York City's reservoirs, differed on most days from observed flow. Occasionally, variations in the components were partially compensating and observed flows compared favorably with forecasted flows. 
On any given day, forecasted releases and actual releases can differ considerably. The ranges of actual daily releases from August 6 to August 30, 2006, are as follows: daily releases at Lake Wallenpaupack differed from forecasted releases by $44 \mathrm{ft}^{3} / \mathrm{s}$ less to $835 \mathrm{ft}^{3} / \mathrm{s}$ more, and daily releases at Rio Reservoir differed from forecasted releases by $152 \mathrm{ft}^{3} / \mathrm{s}$ less to $121 \mathrm{ft}^{3} / \mathrm{s}$ more. On the basis of observed flows at Montague, total directed releases from New York City's Delaware Basin reservoirs during the report year were about 38 percent more than required for exact forecasting.

Comparison of hydrographs of forecasted daily runoff and observed daily runoff from the uncontrolled area (fig. 5) indicates that the forecasts generally were suitable for use in designing releases from New York City's Delaware Basin reservoirs. Numerical adjustments to the designs were made when needed to compensate for errors in the forecasts, but, because of travel times, the effects of the adjustments on flows at Montague were not evident until several days after the design date.

Analysis of the precipitation forecasts shows that the total precipitation amount forecasted for the 3-day design periods is reasonably accurate, but often the actual timing of precipitation events may be

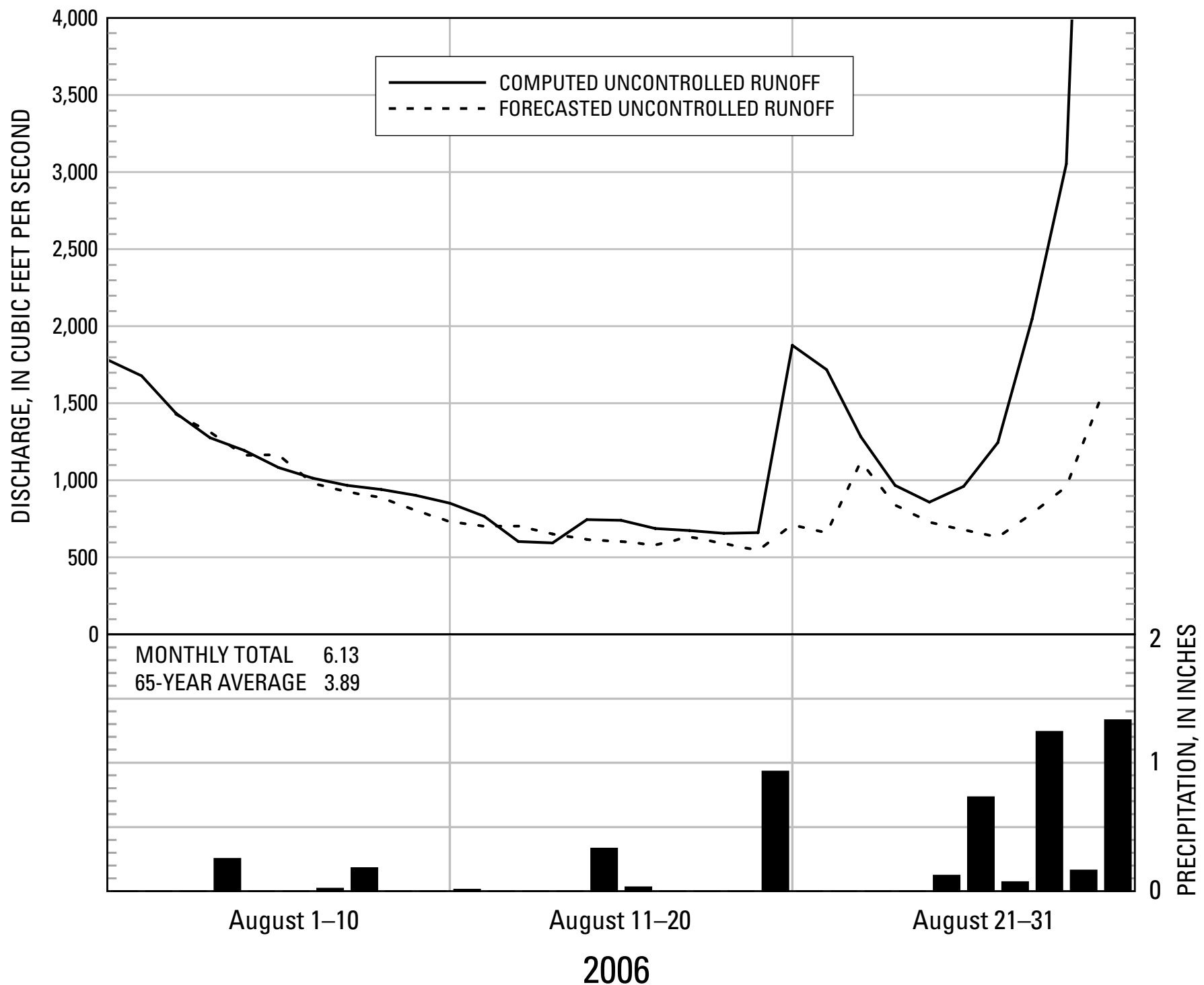

Figure 5. Uncontrolled runoff component, Delaware River at Montague, New Jersey, August 2006. 
earlier or later than forecasted. The accuracy of the runoff forecasts is affected greatly by the timing of precipitation events. In addition, if the actual storm track differs from the forecasted track, the amount and timing of runoff can be substantially different than predicted.

\section{Diversions to New York City Water Supply}

The 1954 Amended Decree authorizes New York City to divert water from the Delaware River Basin at a rate not to exceed the equivalent of $800 \mathrm{Mgal} / \mathrm{d}$. The Decree specifies that the diversion rate shall be computed as the aggregate total diversion beginning June 1 of each year divided by the number of days elapsed since the preceding May 31.

Daily diversions during the report year from Pepacton, Cannonsville, and Neversink Reservoirs to the New York City water-supply system (Rondout Reservoir) are given in table 10. A running account of the average rates of combined diversions from the three reservoirs, computed as stipulated by the Decree, also is shown. The following tabulation shows allowable maximum diversion rates and average actual diversions for various periods during the report year.

\begin{tabular}{lcc}
\hline \multicolumn{1}{c}{ Effective dates } & $\begin{array}{c}\text { Allowable diversion } \\
\text { (Mgal/d) }\end{array}$ & $\begin{array}{c}\text { Average } \\
\text { actual diversion } \\
\text { (Mgal/d) }\end{array}$ \\
\hline December 1, 2005 to May 31, 2006 & 800 & 464 \\
June 1 to November 30, 2006 & 800 & 431 \\
\hline
\end{tabular}

During the report year, a total of 138.091 Bgal of water was diverted to the New York City watersupply system. The allowable diversion was 328.108 Bgal.

\section{Storage in New York City Reservoirs}

The following tabulation summarizes the "point of maximum depletion" and other pertinent levels and contents of Pepacton, Cannonsville, and Neversink Reservoirs. This information was provided by the New York City Board of Water Supply.

\begin{tabular}{|c|c|c|c|c|c|c|}
\hline \multirow[b]{2}{*}{ Level } & \multicolumn{2}{|c|}{ Pepacton Reservoir } & \multicolumn{2}{|c|}{ Cannonsville Reservoir } & \multicolumn{2}{|c|}{ Neversink Reservoir } \\
\hline & $\begin{array}{c}\text { Elevation } \\
\text { (ft) }\end{array}$ & $\begin{array}{l}\text { Contents } \\
\text { (Bgal) }\end{array}$ & $\begin{array}{c}\text { Elevation } \\
\text { (ft) }\end{array}$ & $\begin{array}{l}\text { Contents } \\
\text { (Bgal) }\end{array}$ & $\begin{array}{c}\text { Elevation } \\
\text { (ft) }\end{array}$ & $\begin{array}{c}\text { Contents } \\
\text { (Bgal) }\end{array}$ \\
\hline $\begin{array}{l}\text { Full pool or } \\
\text { spillway crest }\end{array}$ & $1,280.00$ & $* 140.190$ & $1,150.00$ & *95.706 & $1,440.00$ & $* 34.941$ \\
\hline $\begin{array}{l}\text { Point of maxi- } \\
\text { mum depletion }\end{array}$ & $1,152.00$ & $* 3.511$ & $1,040.00$ & $* 1.020$ & $1,319.00$ & $* 0.525$ \\
\hline $\begin{array}{l}\text { Sill of diversion } \\
\text { tunnel }\end{array}$ & $1,143.00$ & $* 4.200$ & $+1,035.00$ & $* 1.564$ & $1,314.00$ & \\
\hline $\begin{array}{l}\text { Sill of river } \\
\quad \text { outlet tunnel }\end{array}$ & $1,126.50$ & & $1,020.50$ & & $1,314.00$ & \\
\hline Dead storage & & 1.800 & & 0.328 & & 1.680 \\
\hline
\end{tabular}

*Contents shown are quantities stored between listed elevations.

+Elevation of mouth of inlet channel of diversion works. 
Daily storage in Pepacton, Cannonsville, and Neversink Reservoirs, above the "point of maximum depletion" or minimum full-operating level, is given in tables 3, 4, and 5 .

On December 1, 2005, combined storage in the three reservoirs was $213.173 \mathrm{Bgal}$, or 78.7 percent of combined capacity. Combined storage increased in early winter and remained at high levels throughout the year. Storage during the report year did not decline below 78 percent of total capacity. The three reservoirs spilled a total of $309.136 \mathrm{Bgal}$ during the year. Combined storage reached a maximum for the report year on June 29, 2006, at 289.426 Bgal. Combined storage was 270.643 Bgal, or 99.9 percent of combined capacity, on November 30, 2006.

\section{Comparison of River Master Operations Data With Other Streamflow Records}

River Master operations are conducted on a day-to-day basis and, by necessity, use preliminary data on streamflow. In this section, records used in River Master operations are compared to final data published for selected USGS gaging stations. Data on releases were reported in million gallons per day and converted to cubic feet per second for use in the comparisons.

\section{Releases from New York City Reservoirs}

River Master operations data on controlled releases from Pepacton, Cannonsville, and Neversink Reservoirs to the Delaware River were furnished by the New York City Department of Environmental Protection. These data were obtained from calibrated instruments connected to venturi meters installed in the outlet conduits of the reservoirs.

The USGS gaging station on East Branch Delaware River at Downsville, New York, is 0.5 mile downstream from Downsville Dam (fig. 1). Discharge measured at this station includes releases from Pepacton Reservoir and a small amount of seepage and any runoff that enters the channel between the dam and the gaging station. The drainage area is $371 \mathrm{mi}^{2}$ at the dam and $372 \mathrm{mi}^{2}$ at the gaging station.

The following tabulation compares releases from Pepacton Reservoir (table 9), reported by New York City, to the final records for the USGS gaging station on East Branch Delaware River at Downsville, New York (table 11), for the flow objectives shown.

\begin{tabular}{lc|c|c|c|c}
\hline Flow objective $\left(\mathrm{ft}^{3} / \mathrm{s}\right)$ & 12 & 36 & 85 & 186 & 699 \\
Number of USGS daily mean discharge values used in comparison & 11 & 26 & 8 & 14 & 13 \\
New York City-measured mean flow $\left(\mathrm{ft}^{3} / \mathrm{s}\right)$ & 12.4 & 35.6 & 85.1 & 186 & 699 \\
USGS-computed mean flow $\left(\mathrm{ft}^{3} / \mathrm{s}\right)$ & 16.1 & 41.8 & 80.0 & 172 & 705 \\
Percent difference & -23.0 & -14.8 & +6.4 & +8.1 & -0.9 \\
\hline
\end{tabular}

The differences at the four higher flow objectives are less than 15 percent. The instruments connected to the venturi meters were recalibrated periodically by New York City to improve the accuracy of the recorded flow data.

The USGS gaging station on West Branch Delaware River at Stilesville, New York, is 1.4 miles downstream from Cannonsville Dam (fig. 1). Discharge measured at this station includes releases from Cannonsville Reservoir and runoff from $2 \mathrm{mi}^{2}$ of drainage area between the dam and the gaging station. The drainage area is $454 \mathrm{mi}^{2}$ at the dam and $456 \mathrm{mi}^{2}$ at the gaging station. The gaging-station records are rated 
fair at flows greater than $100 \mathrm{ft}^{3} / \mathrm{s}$ and poor at flows less than $100 \mathrm{ft}^{3} / \mathrm{s}$. A rating of "fair" means that about 95 percent of the daily discharges are within 15 percent of the true discharge, whereas a rating of "poor" means that daily discharges have less than "fair" accuracy. The records include runoff from the area between the dam and the gaging station, and seepage near the base of the dam.

The following tabulation compares releases from Cannonsville Reservoir (table 9), reported by New York City, to the final records for the USGS gaging station on West Branch Delaware River at Stilesville, New York (table 12), for the flow objectives shown.

\begin{tabular}{ll|r}
\hline Flow objective $\left(\mathrm{ft}^{3} / \mathrm{s}\right)$ & 46 & 1,000 \\
Number of USGS daily mean discharge values used in comparison & 19 & 27 \\
New York City-measured mean flow $\left(\mathrm{ft}^{3} / \mathrm{s}\right)$ & 46.4 & 1,000 \\
USGS-computed mean flow $\left(\mathrm{ft}^{3} / \mathrm{s}\right)$ & 54.8 & 1,020 \\
Percent difference & -15.3 & -2.0 \\
\hline
\end{tabular}

The USGS gaging station on Neversink River at Neversink, New York, is 1,650 ft downstream from Neversink Dam (fig. 1). Discharge measured at this station includes releases from Neversink Reservoir and, during storms, a small amount of runoff that originates between the dam and the gaging station. The drainage area is $92.5 \mathrm{mi}^{2}$ at the dam and $92.6 \mathrm{mi}^{2}$ at the gaging station.

The following tabulation compares releases from Neversink Reservoir (table 9), reported by New York City, to the final records for the USGS gaging station on Neversink River at Neversink, New York (table 13), for the flow objectives shown.

\begin{tabular}{lllrr}
\hline Flow objective $\left(\mathrm{ft}^{3} / \mathrm{s}\right)$ & 25 & 65 & 108 & 190 \\
Number of USGS daily mean discharge values used in comparison & 49 & 23 & 6 & 21 \\
New York City-measured mean flow $\left(\mathrm{ft}^{3} / \mathrm{s}\right)$ & 24.8 & 65.0 & 108 & 191 \\
USGS-computed mean flow $\left(\mathrm{ft}^{3} / \mathrm{s}\right)$ & 26.8 & 64.0 & 112 & 183 \\
Percent difference & -7.5 & +1.6 & -3.6 & +4.4 \\
\hline
\end{tabular}

The differences at the four flow objectives are less than 8 percent. The comparison excludes data for the period from February 20 to June 6, 2006. During this period, the two records differ significantly, with greater flow indicated by the USGS gaging station record. The USGS record was estimated during this period and was downgraded because of heavy debris accumulations on the artificial control.

\section{Delaware River at Montague, New Jersey}

The River Master's operations record for the Delaware River at Montague, New Jersey (table 9), showed about 0.1 percent less discharge for the report year than the published USGS record for the gaging station (table 14). Daily values for the two records agreed closely, except during ice-affected periods.

\section{Diversion Tunnels}

Records of diversions through the East Delaware, West Delaware, and Neversink Tunnels (fig. 1) were furnished by the New York City Department of Environmental Protection. These records were obtained from the City's calibrated instruments connected to venturi meters installed in the tunnel conduits. The measured flows were transmitted electronically on a 15-second interval to a City computer and, on 5-minute intervals, release and diversion quantities for the preceding 5-minute period were computed using 
the instantaneous rate-of-flow data from each instrument. These 5-minute quantities were then summed to compute daily total flows, which were reported to the River Master's office on a daily basis. On a weekly basis, the diversion figures were checked against the flow meter totalizer readings and corrected when necessary.

The East Delaware Tunnel is used to divert water from Pepacton Reservoir to Rondout Reservoir. Conditions in the outlet channel of the East Delaware Tunnel were unfavorable for flow measurements during the report year because of high water levels in Rondout Reservoir.

The generating plant at the downstream end of the East Delaware Tunnel operated most days of the report year. When the powerplant was not in operation, some water leaked through the wicket gates and was not recorded on the totalizer. A current-meter measurement made in 1989 shows that the (assumed constant) rate of leakage is about $8.0 \mathrm{Mgal} / \mathrm{d}$. Because the powerplant was not in operation for the equivalent of 180 days during the 2006 report year, the estimated quantity of unmeasured leakage was about 1.4 Bgal.

The West Delaware Tunnel is used to divert water from Cannonsville Reservoir to Rondout Reservoir. Inspections of the channel below the outlet, when valves were closed, revealed only negligible leakage. A hydroelectric powerplant uses water diverted through the West Delaware Tunnel, but the plant operates only when diversions are less than $300 \mathrm{Mgal} / \mathrm{d}$. When the powerplant is not operating, the valves on the pipelines to the plant are closed, and there is no leakage through the system.

The Neversink Tunnel is used to divert water from Neversink Reservoir to Rondout Reservoir. A hydroelectric powerplant uses water diverted through the Neversink Tunnel. When the powerplant is not operating and the main valve on the diversion tunnel is open, leakage develops that is not recorded on the venturi instruments. One current-meter measurement made in 1999 showed a leakage rate of $16.2 \mathrm{ft}^{3} / \mathrm{s}$ $(10.5 \mathrm{Mgal} / \mathrm{d})$. When the powerplant is operating, the leakage is included in the recorded flow. No leakage occurs when the main valve on the tunnel is closed. During the 2006 report year, the powerplant operated part of the day on most days and was not operated the equivalent of 236 days. Using the leakage rate noted above and records of powerplant operation, about 2.5 Bgal of water was diverted but not recorded.

\section{Diversions by New Jersey}

The Amended Decree authorizes New Jersey to divert water from the Delaware River and its tributaries in New Jersey, to areas outside of the Delaware River Basin, without compensating releases. These diversions may not exceed $100 \mathrm{Mgal} / \mathrm{d}$ as a monthly average, and the daily mean diversion may not exceed $120 \mathrm{Mgal} / \mathrm{d}$. The USGS gaging station on Delaware and Raritan Canal at Port Mercer, New Jersey (fig. 1), is used as the official control point for measuring diversions by New Jersey (table 15).

The following tabulation shows the allowable diversion by New Jersey, the period it was in effect, and the maximum monthly diversion during the report year.

\begin{tabular}{lccc}
\hline Effective dates & $\begin{array}{c}\text { Allowable monthly } \\
\text { average diversion } \\
\text { (Mgal/d) }\end{array}$ & $\begin{array}{c}\text { Maximum monthly } \\
\text { average diversion } \\
\text { (Mgal/d) }\end{array}$ & $\begin{array}{c}\text { Month of maximum } \\
\text { average diversion }\end{array}$ \\
\hline Dec. 1, 2005 to Nov. 30, 2006 & 100 & 98.8 & July \\
\hline
\end{tabular}


The maximum daily mean diversion was 110 Mgal on December 15, 2005. Diversions by New Jersey did not exceed the limits stipulated by the Decree.

\section{Conformance of Operations Under the Amended Decree of the U.S. Supreme Court Entered June 7, 1954}

From December 1, 2005 to November 30, 2006, operations of the Delaware River Master were conducted as stipulated by the Decree.

Diversions from the Delaware River Basin to the New York City water-supply system did not exceed those authorized by the Decree. Under compensating releases of the Montague Formula, New York City released water from its reservoirs at rates designed by the River Master to meet the applicable flow objectives at Montague, New Jersey. During the report year, New York City complied fully with all directives and requests of the River Master.

Diversions from the Delaware River Basin by New Jersey were within limits stipulated by the Decree. New Jersey complied fully with all directives and requests of the River Master. 
Table 1. Precipitation in the Delaware River Basin above Montague, New Jersey.

(Source: National Weather Service, New York City Department of Environmental Protection, and Office of the Delaware River Master)

[All values, except percentages, in inches]

\begin{tabular}{|c|c|c|c|c|c|}
\hline \multirow[b]{3}{*}{ Month } & \multirow{3}{*}{$\begin{array}{c}\text { December } 1940 \text { to } \\
\text { November } 2005 \\
\text { Monthly Average }\end{array}$} & \multicolumn{4}{|c|}{ December 2005 to November 2006} \\
\hline & & \multirow[b]{2}{*}{ Amount } & \multirow{2}{*}{$\begin{array}{c}\text { Percent } \\
\text { of average }\end{array}$} & \multicolumn{2}{|c|}{ Excess (+) or deficit (-) } \\
\hline & & & & Month & Cumulative \\
\hline December & 3.41 & 2.96 & 87 & -.45 & -.45 \\
\hline January & 3.02 & 5.19 & 172 & +2.17 & +1.72 \\
\hline February & 2.61 & 1.56 & 60 & -1.05 & +.67 \\
\hline March & 3.36 & 1.32 & 39 & -2.04 & -1.37 \\
\hline April & 3.76 & 3.80 & 101 & +.04 & -1.33 \\
\hline May & 4.18 & 4.43 & 106 & +.25 & -1.08 \\
\hline June & 4.00 & 11.62 & 290 & +7.62 & +6.54 \\
\hline July & 4.06 & 3.12 & 77 & -.94 & +5.60 \\
\hline August & 3.89 & 6.13 & 158 & +2.24 & +7.84 \\
\hline September & 4.04 & 5.04 & 125 & +1.00 & +8.84 \\
\hline October & 3.54 & 5.16 & 146 & +1.62 & +10.46 \\
\hline November & 3.80 & 4.70 & 124 & +.90 & +11.36 \\
\hline 12 months & 43.67 & 55.03 & 126 & & \\
\hline
\end{tabular}

Table 2. Conservation release rates for New York City reservoirs in the Delaware River Basin. (Source: DRBC Docket No. D-77-20 CP (Revision 7)

[All values in cubic feet per second]

\begin{tabular}{l|l|c|c|c|c}
\hline \multirow{2}{*}{ Reservoir } & \multicolumn{1}{c|}{ Effective dates } & \multicolumn{3}{c}{ Conservation release rates } \\
\cline { 3 - 6 } & \multicolumn{1}{c}{ Pecember 1 to November 30 } & 35 & Watch & Warning & Drought \\
\hline \multirow{3}{*}{ Cannonsville } & December 1 to May 31 & 45 & 38 & 25 & 19 \\
& June 1 to August 31 & 60 & 51 & 32 & 23 \\
& September 1 to November 30 & 45 & 38 & 32 & 23 \\
Neversink & December 1 to November 30 & & & & \\
\hline
\end{tabular}




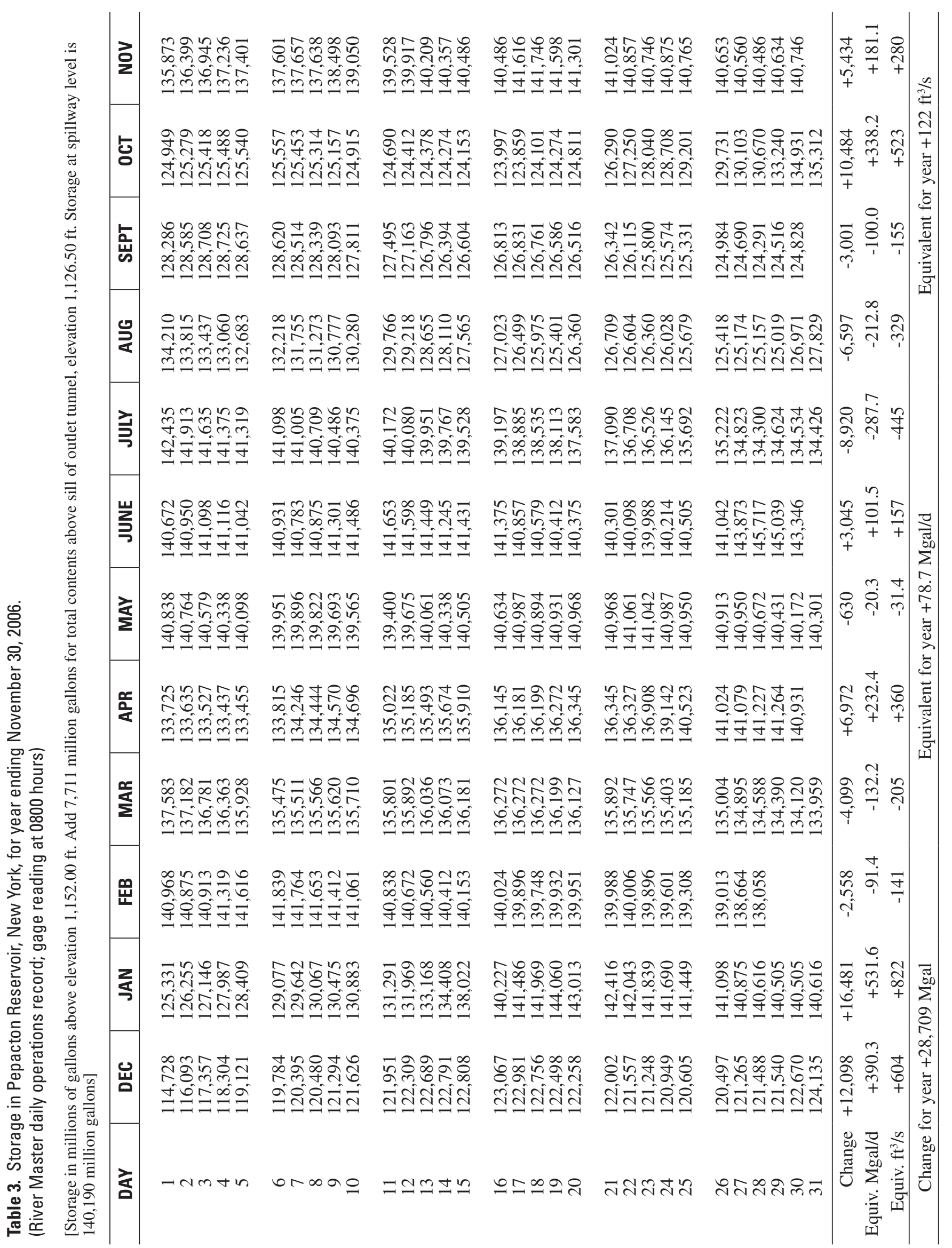




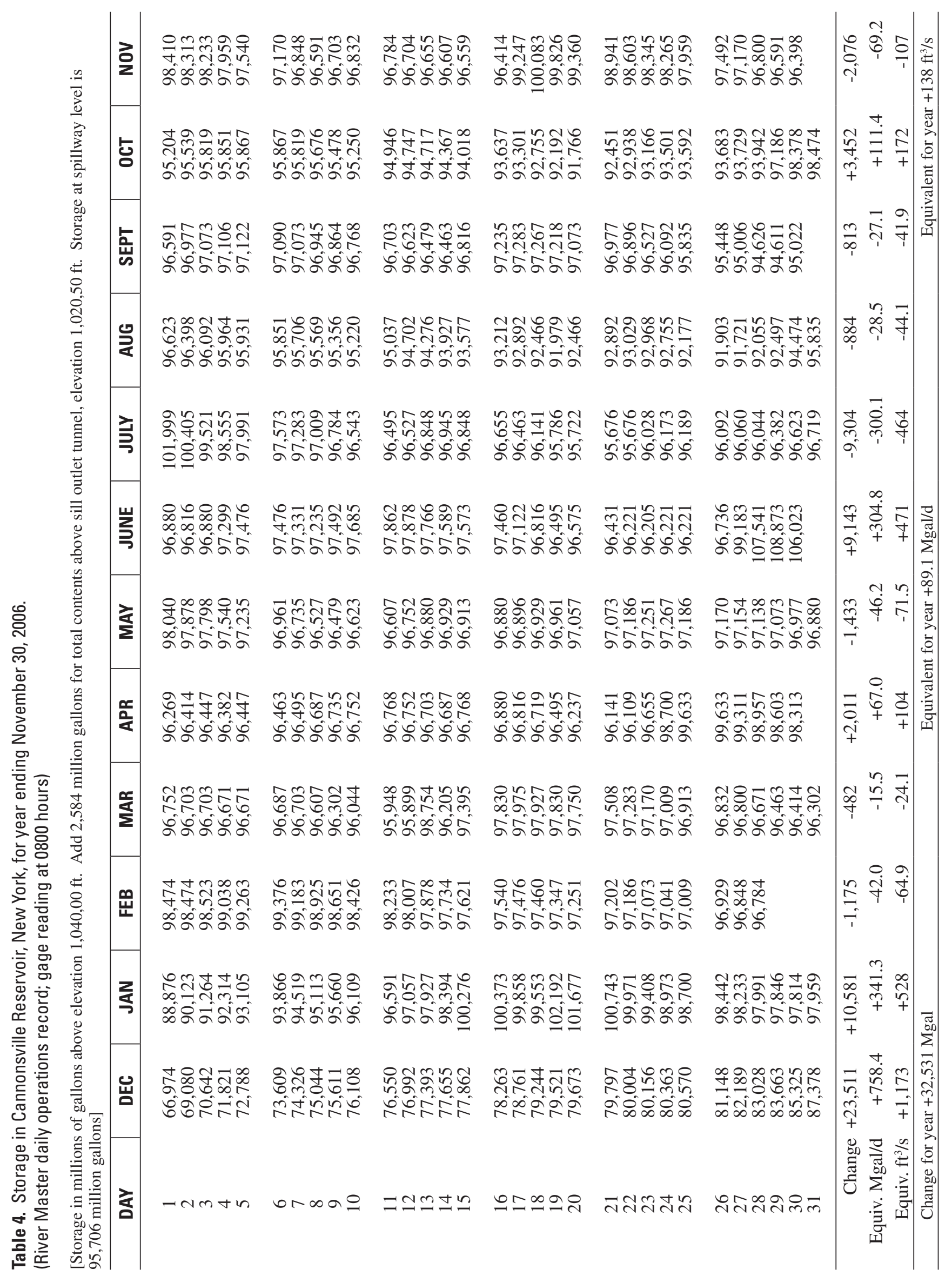




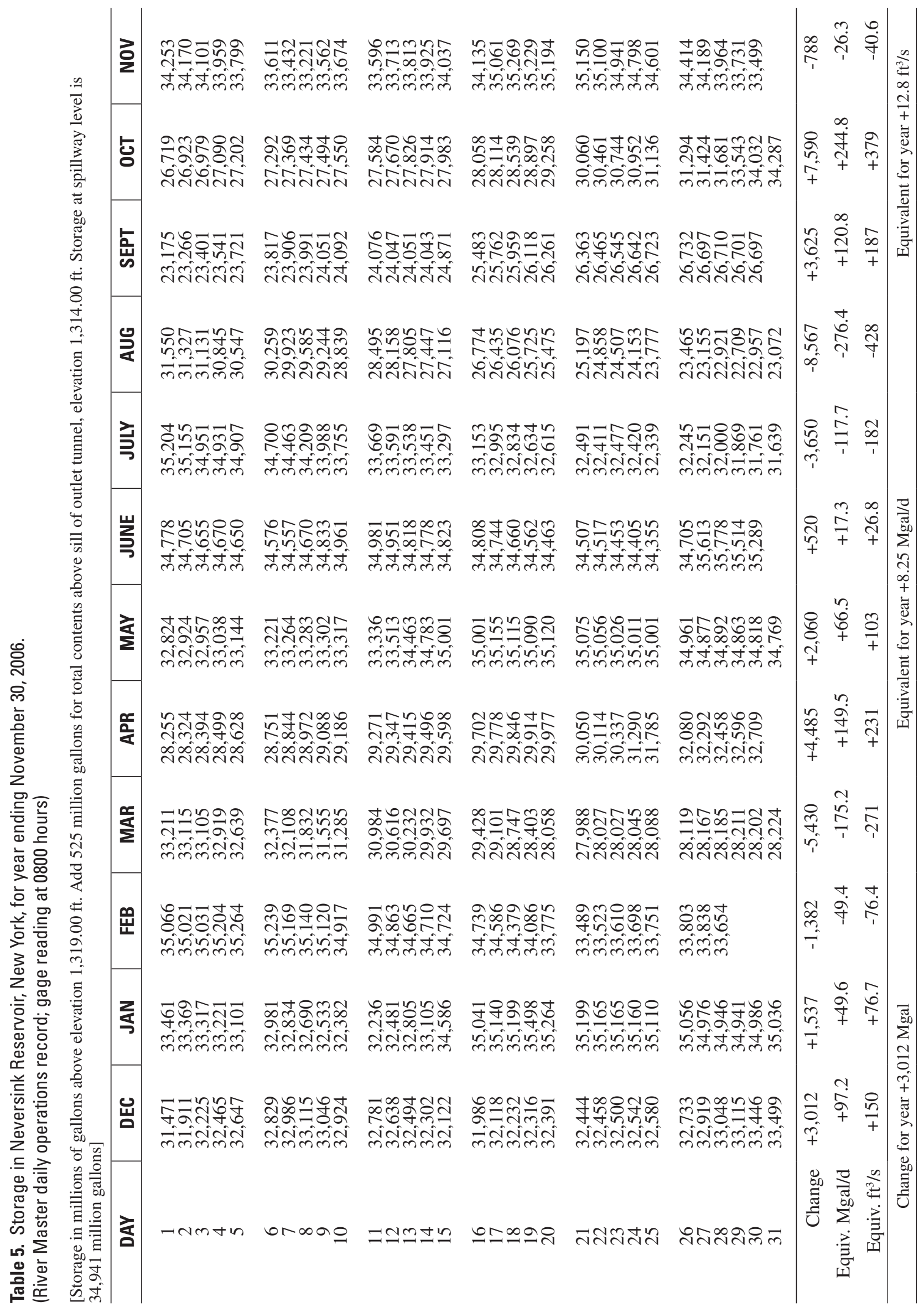


Table 6. Design rates for Delaware River at Montague, New Jersey, gaging station, December 1, 2005 to November 30, 2006. (Source: Office of the Delaware River Master)

[Rates in cubic feet per second]

\begin{tabular}{lc}
\multicolumn{1}{c}{ Effective dates } & Montague Design Rate \\
\hline December 1 to December 18, 2005 & 1,750 \\
December 19, 2005 to March 15, 2006 & 1,800 \\
March 16 to June 14, 2006 & 1,750 \\
June 15 to August 31, 2006 & 1,800 \\
September 1 to November 30, 2006 & 1,750 \\
\hline
\end{tabular}


Table 7. Consumption of water by New York City, 1950 to 2006.

(Source: New York City Department of Environmental Protection, Bureau of Water Supply)

[Mgal/d, million gallons per day; Bgal, billion gallons]

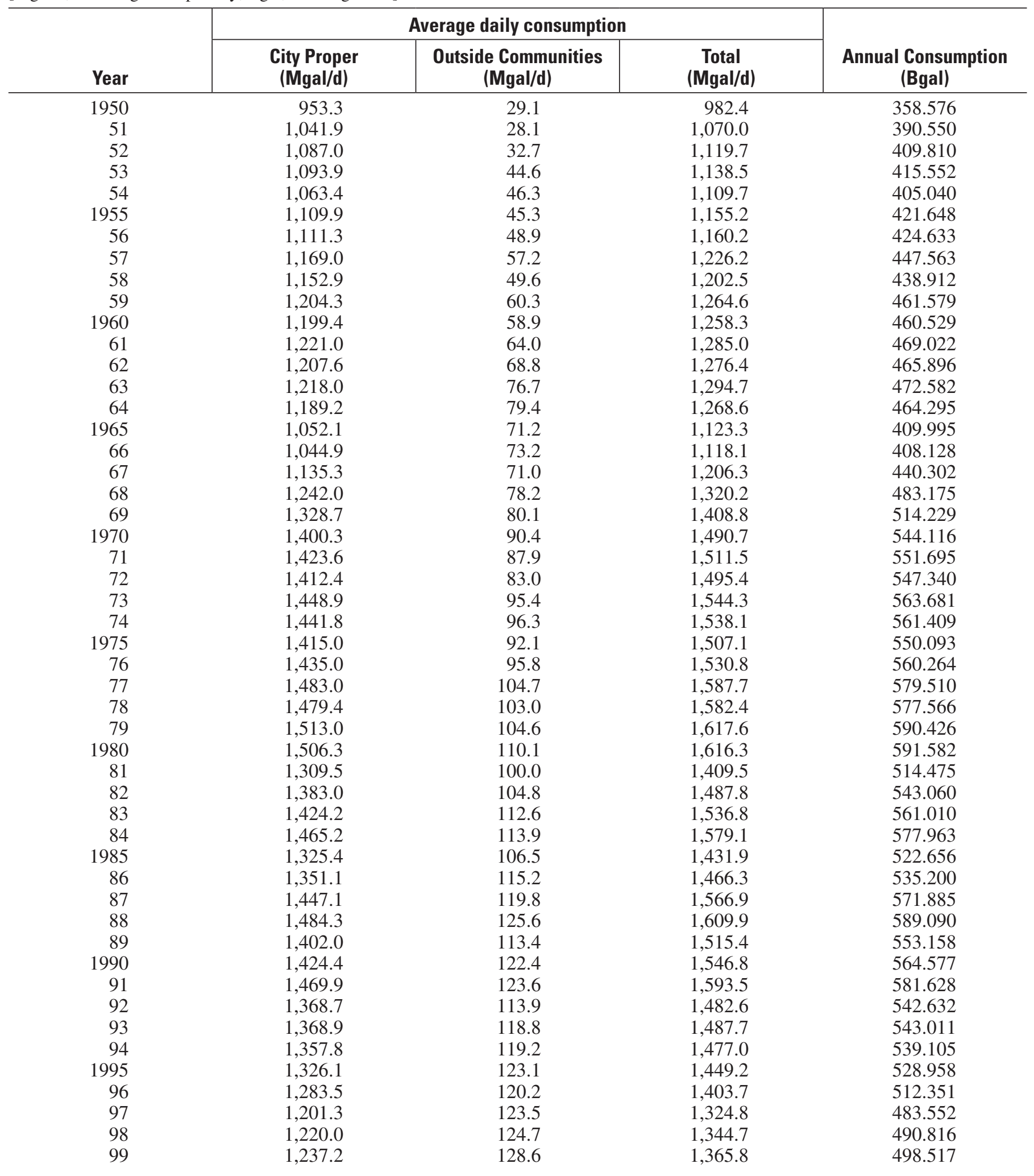


Table 7. Consumption of water by New York City, 1950 to 2006.-Continued

(Source: New York City Department of Environmental Protection, Bureau of Water Supply)

[Mgal/d, million gallons per day; Bgal, billion gallons]

\begin{tabular}{r|c|c|c|c}
\hline \multirow{2}{*}{ Year } & \multicolumn{3}{|c|}{ Average daily consumption } & \multirow{2}{*}{$\begin{array}{c}\text { Annual Consumption } \\
\text { (Bgal) }\end{array}$} \\
\cline { 2 - 4 } & $\begin{array}{c}\text { City Proper } \\
\text { (Mgal/d) }\end{array}$ & $\begin{array}{c}\text { Outside Communities } \\
\text { (Mgal/d) }\end{array}$ & $\begin{array}{c}\text { Total } \\
\text { (Mgal/d) }\end{array}$ & 499.700 \\
2000 & $1,240.4$ & 124.9 & $1,365.3$ & 479.026 \\
01 & $1,184.0$ & 128.4 & $1,312.4$ & 458.696 \\
02 & $1,135.6$ & 121.1 & $1,256.7$ & 441.516 \\
03 & $1,093.7$ & 115.9 & $1,209.6$ & 445.461 \\
04 & $1,099.6$ & 117.5 & $1,217.1$ & 449.462 \\
2005 & $1,107.6$ & 123.8 & $1,231.4$ & 432.890 \\
06 & $1,069.2$ & 116.8 & $1,186.0$ & \\
\hline
\end{tabular}



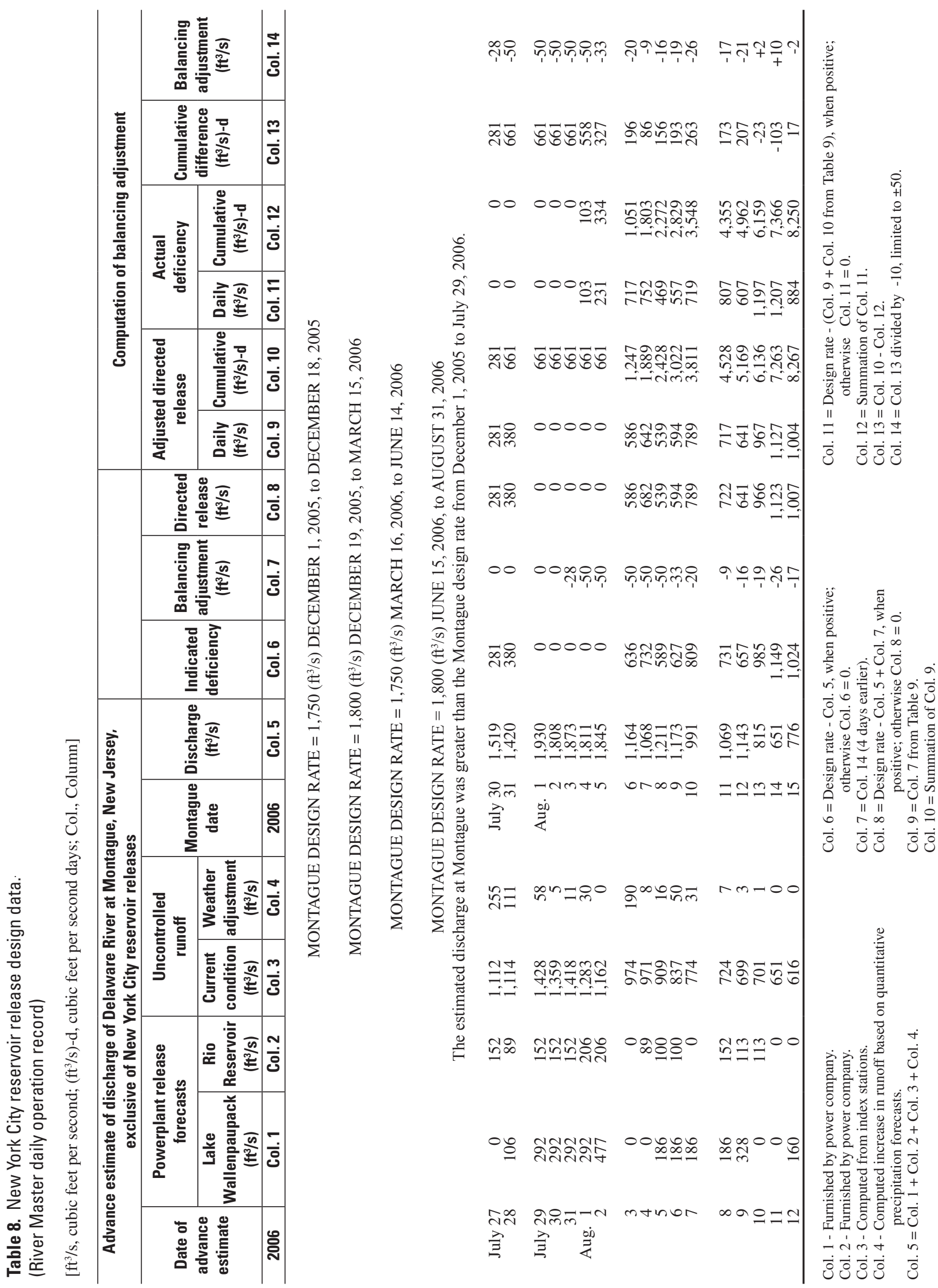


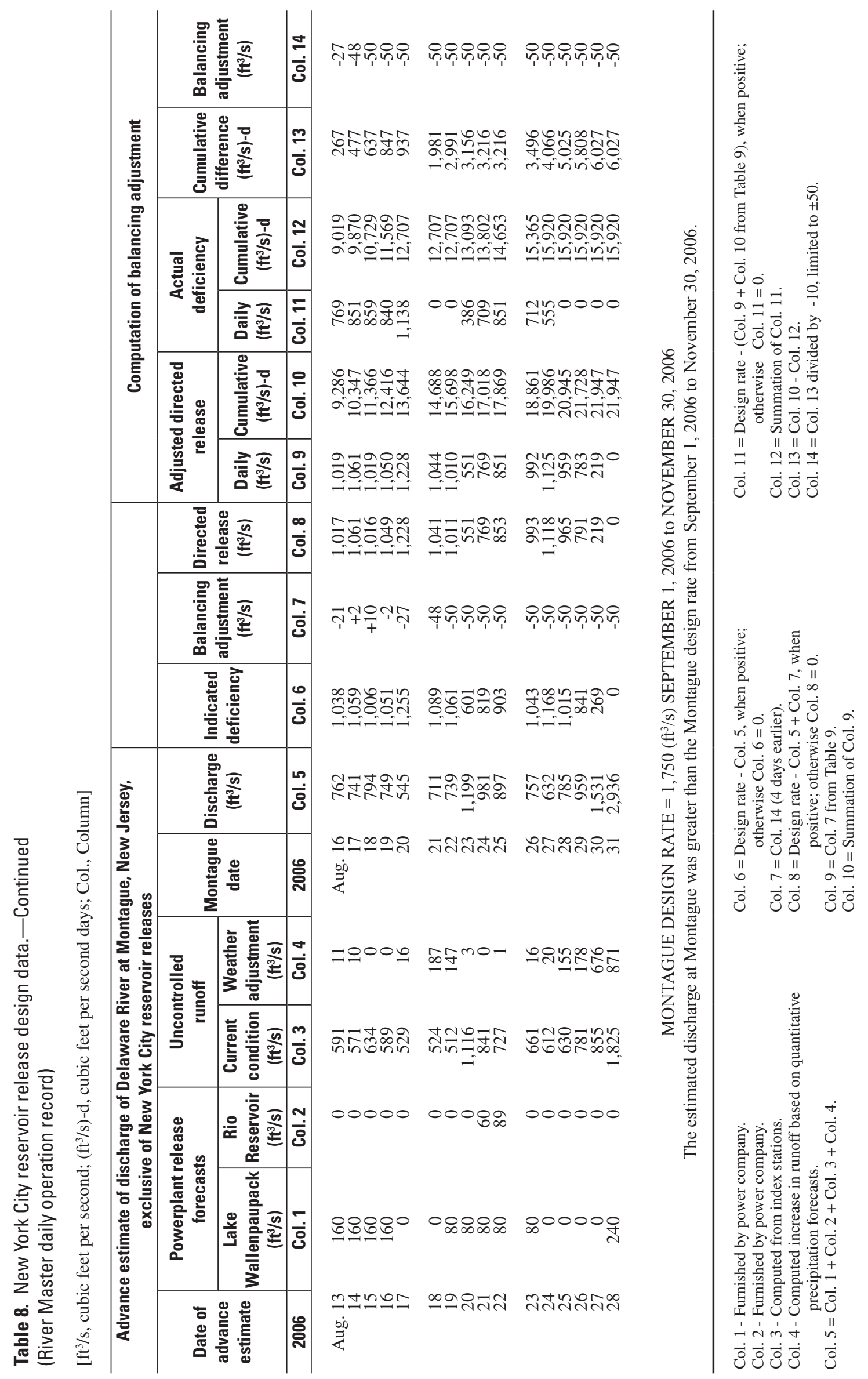




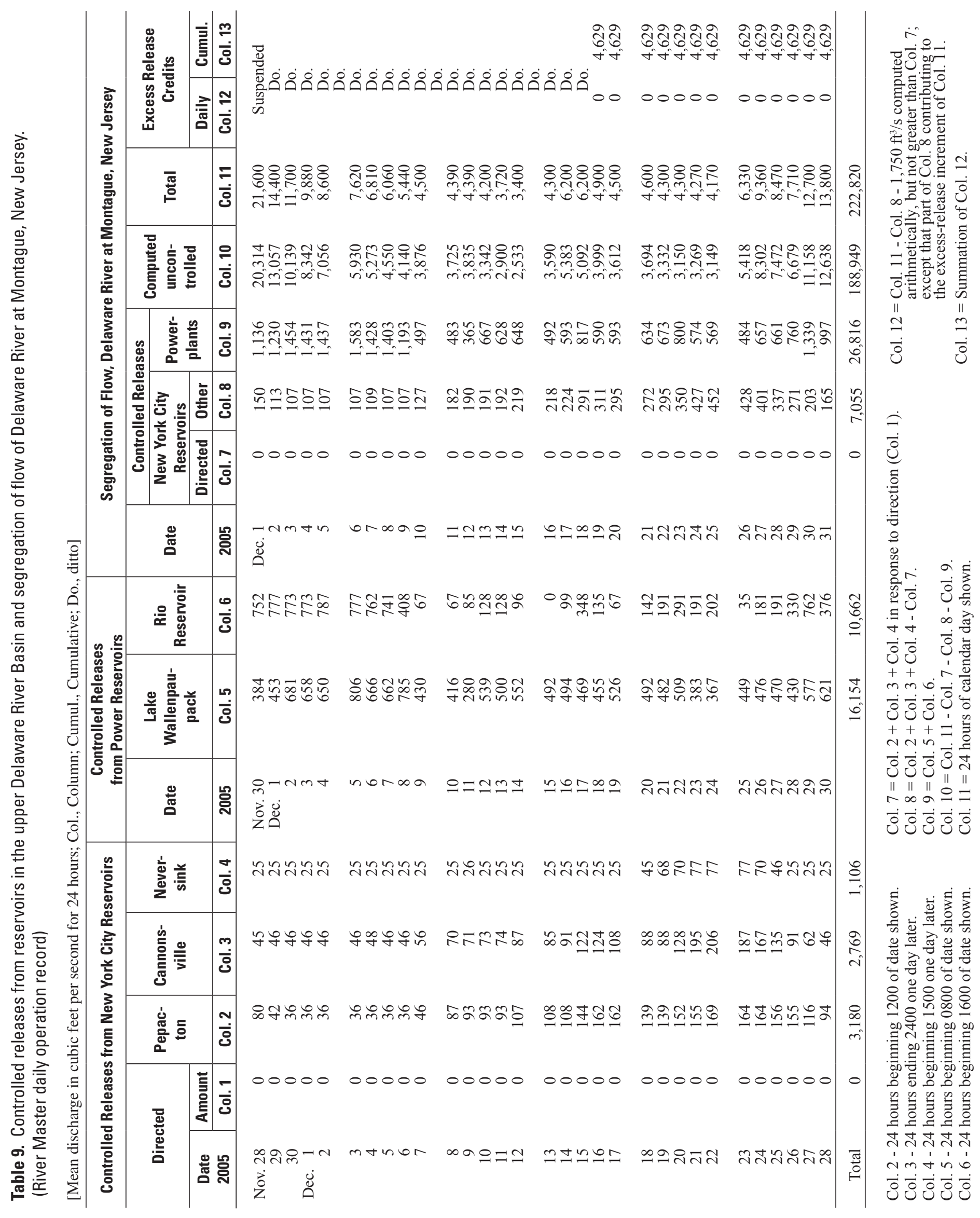




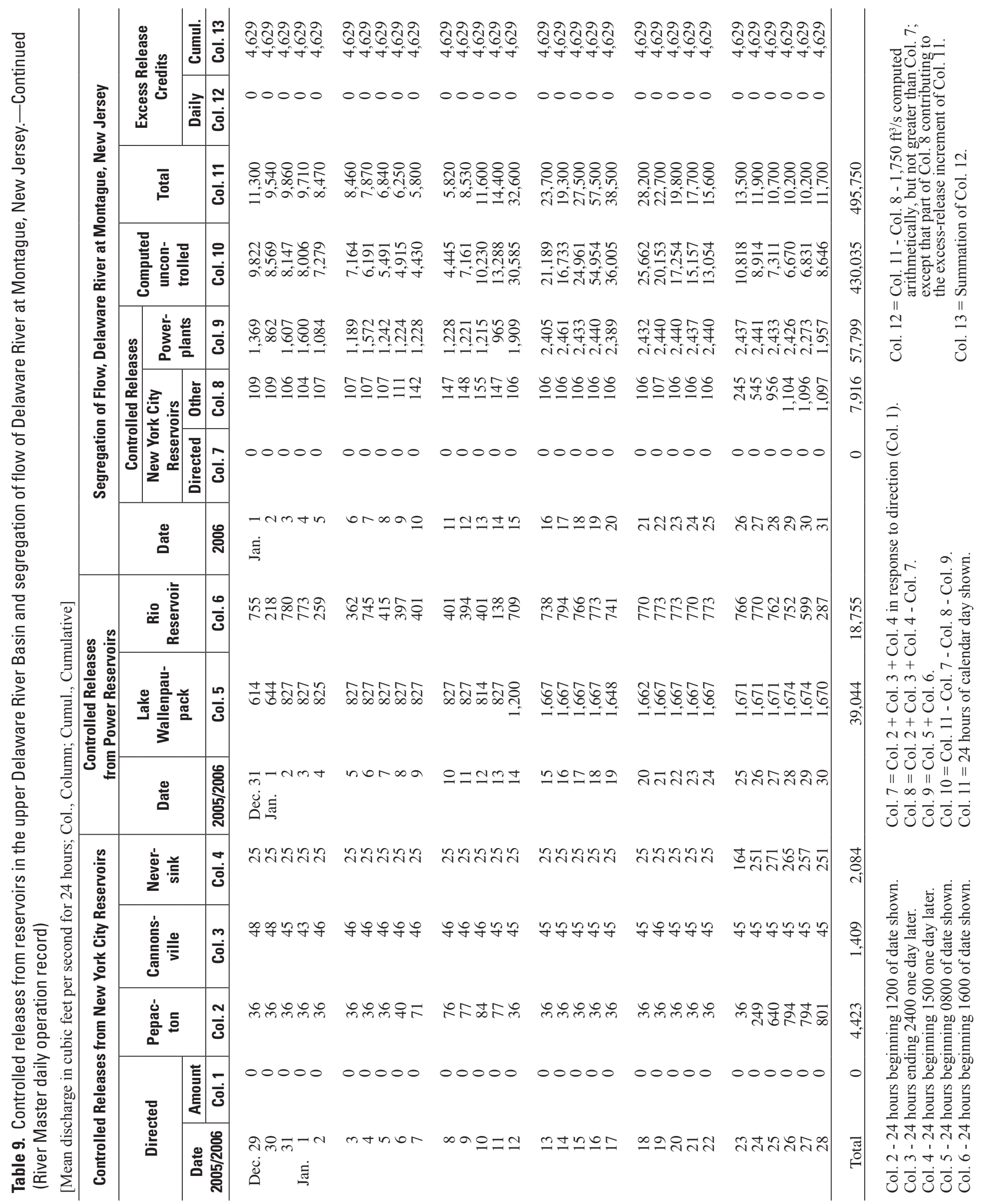




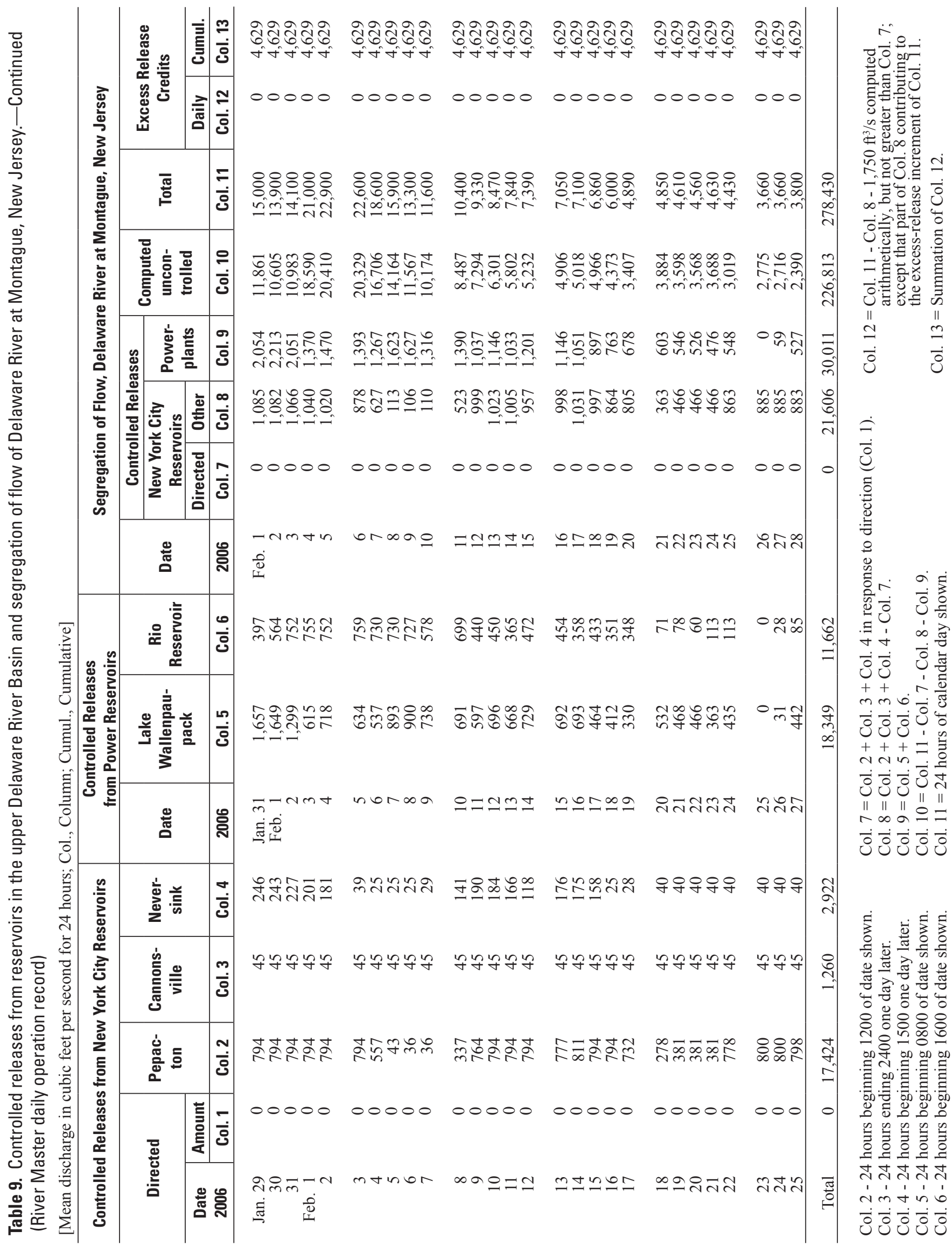




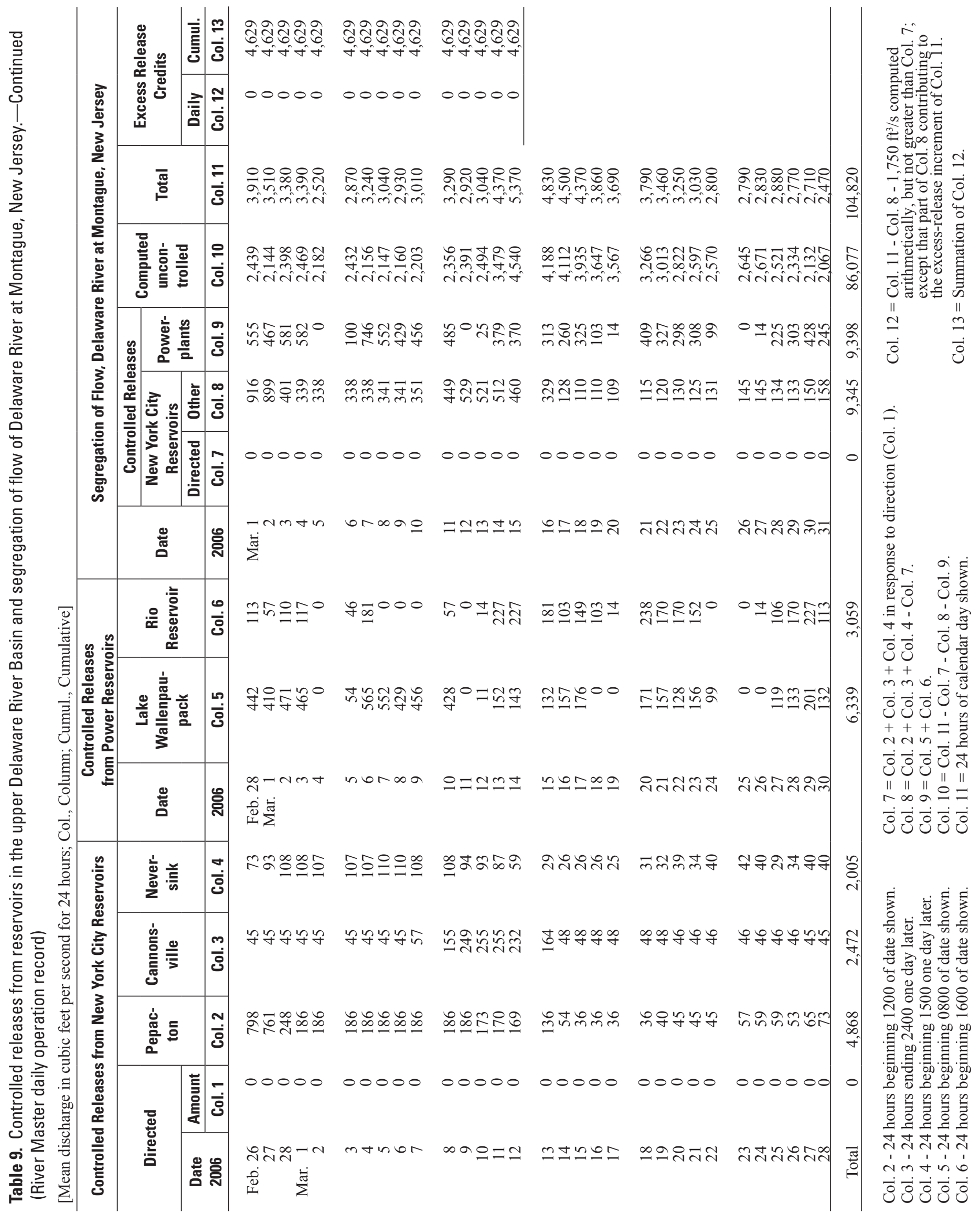




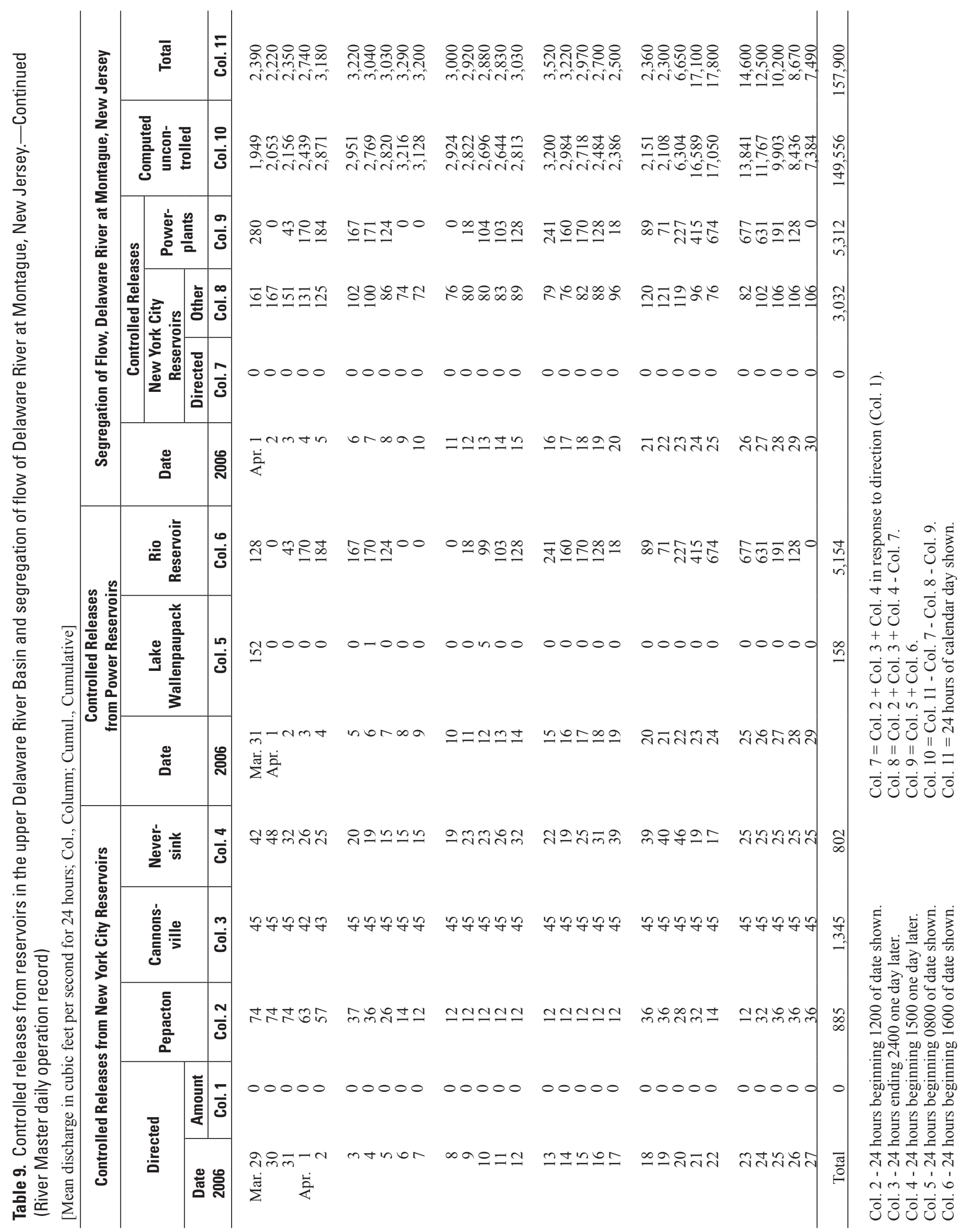




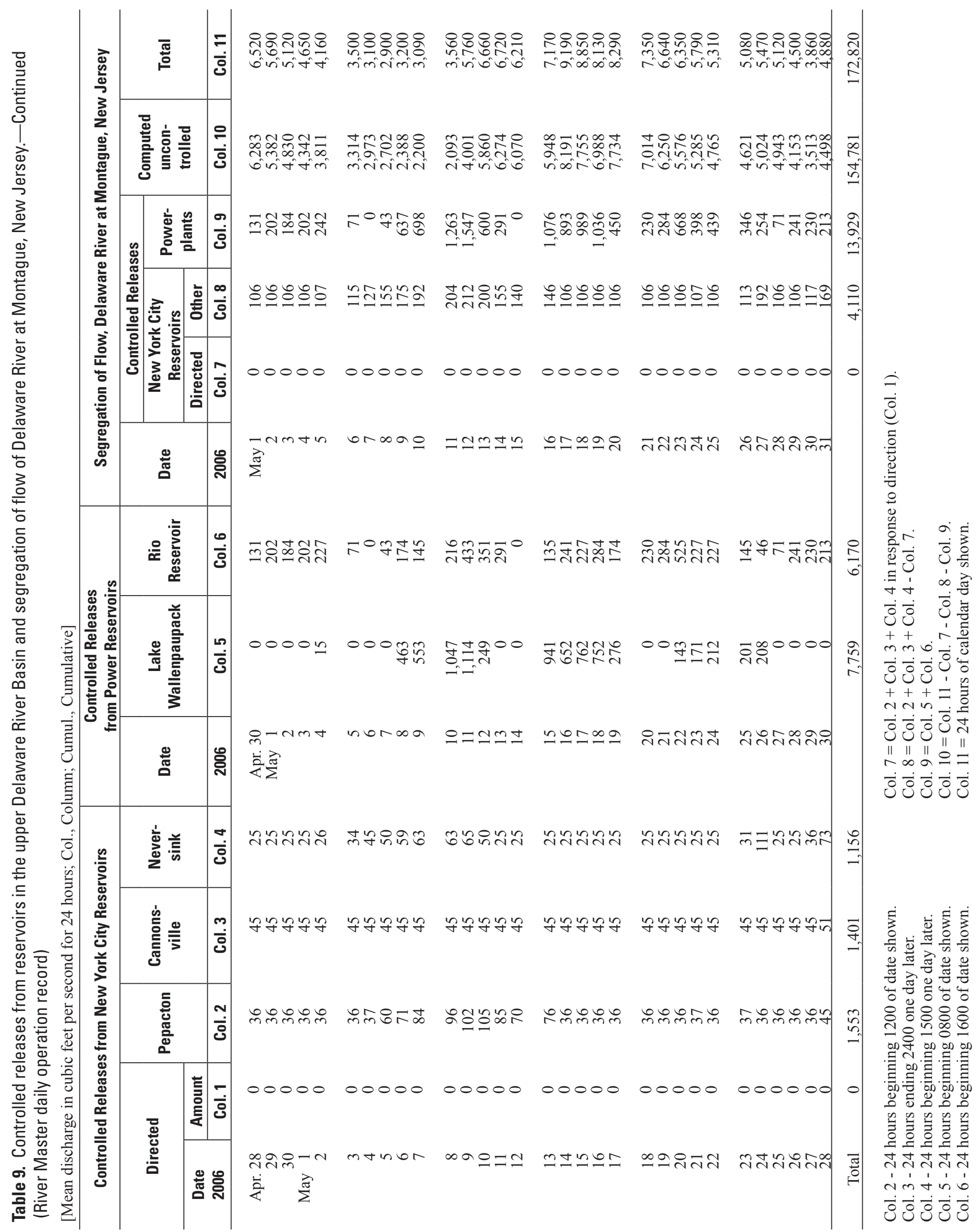



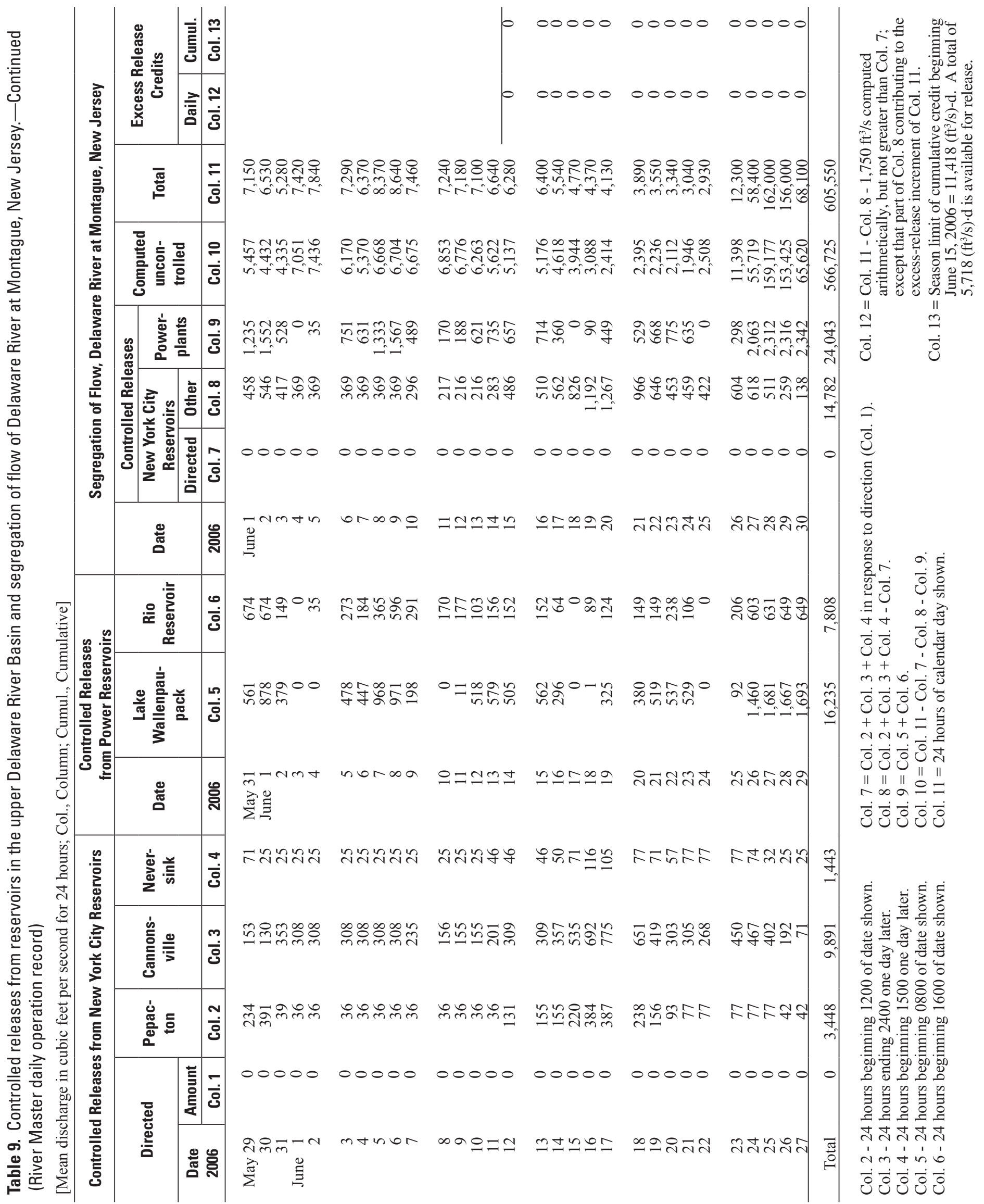

产 至密 专 专 पू 응 융용

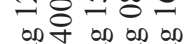
bo f bo bo bo

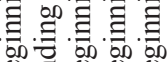
00

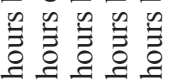
ఫ㠩吉声 त' $\begin{aligned} & 1 \\ & 1\end{aligned}$ ச் 

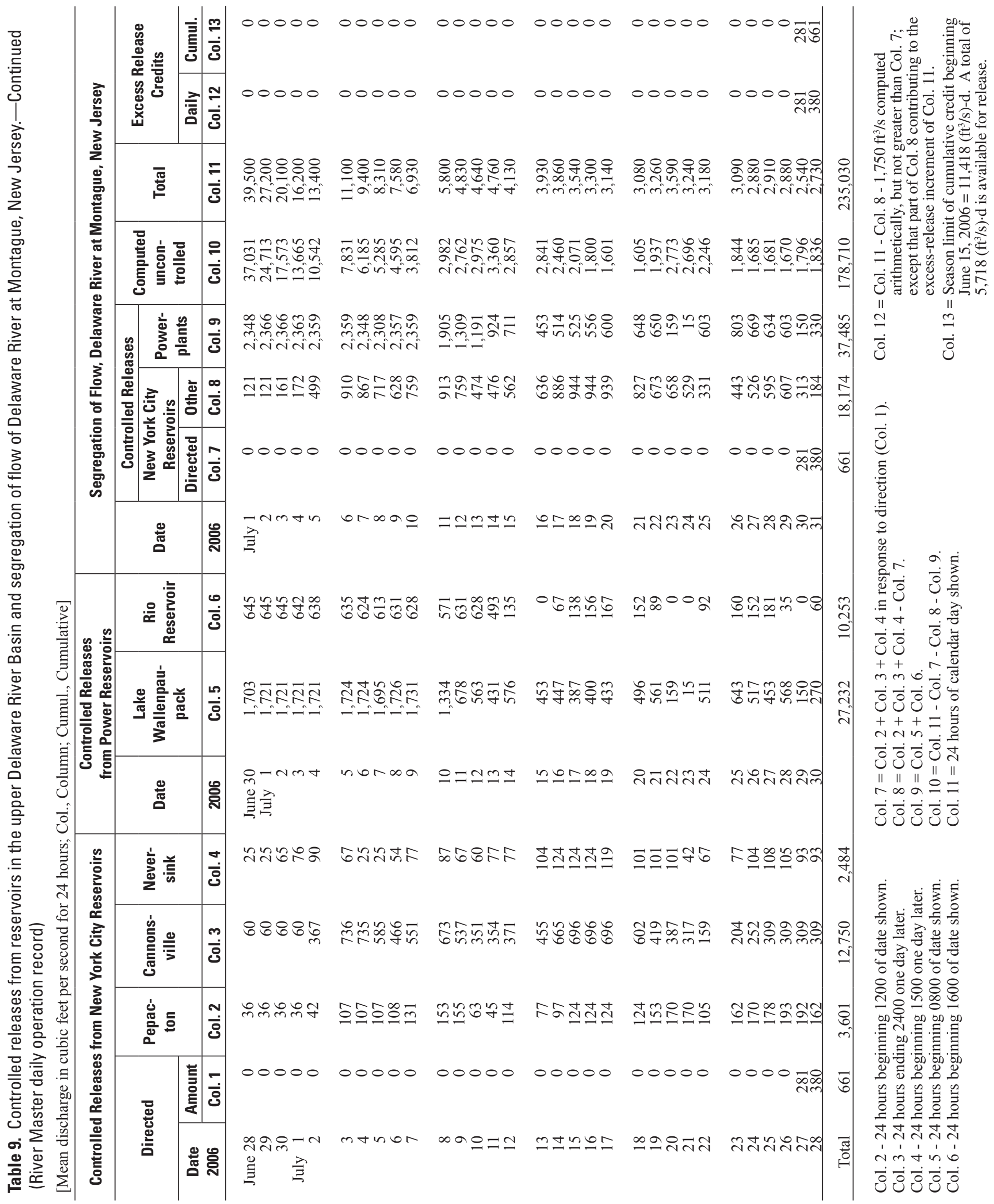

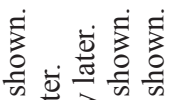
类

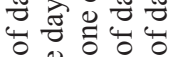
응 888 on 8 ton on 00 自别这目 50 品 웡ㅇ 검검 तें ठ்ல் 


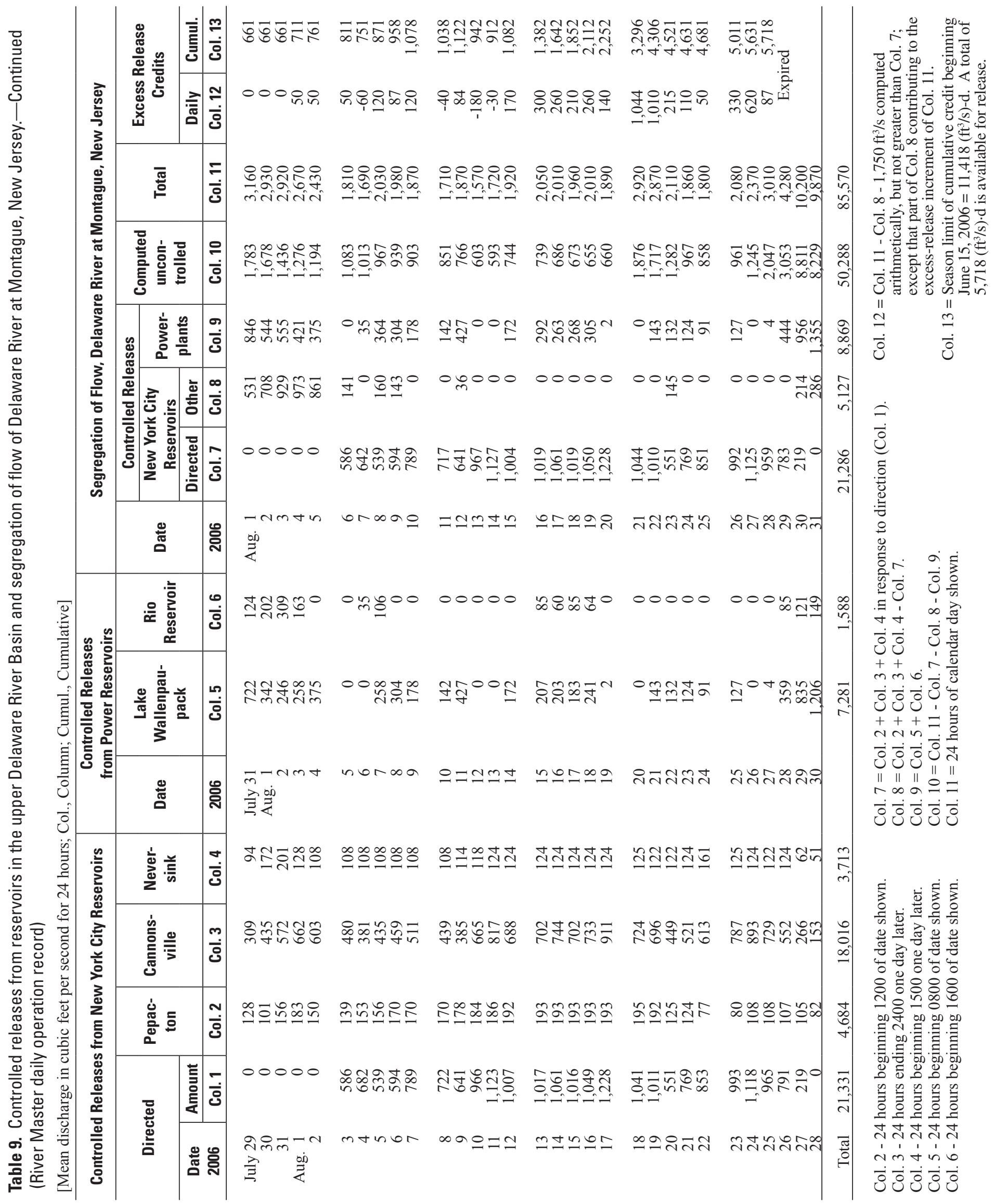



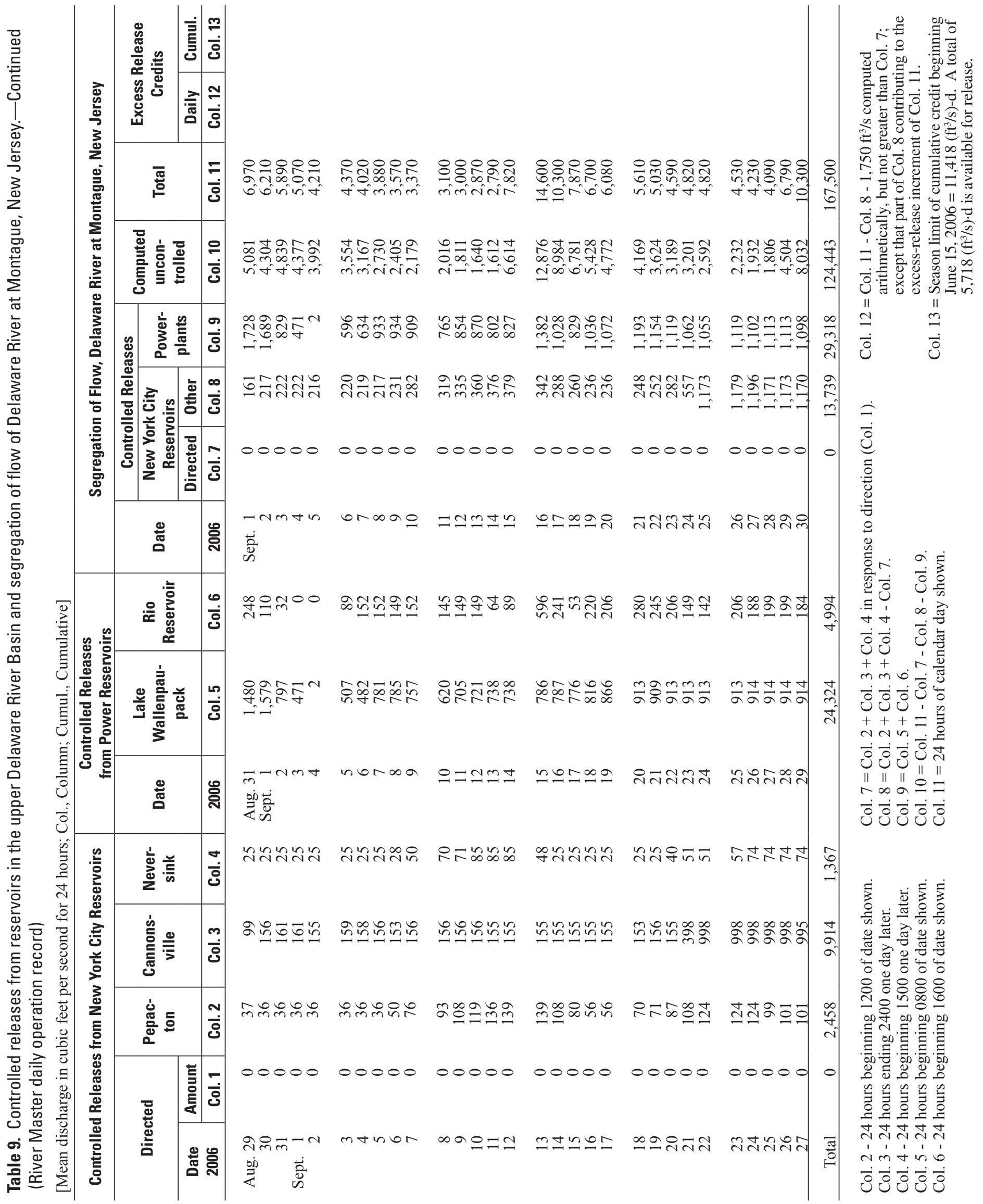

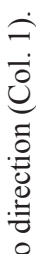

:

क्षें

어

子ं $\infty$

0ं 0 흉

$++r \frac{0}{1}$

mm 0 .

லंठ்

$+++=$ 근

ठ்

\| $\|$ "

ن்

产富言产

至 空

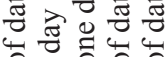

응 8 융

on 억.

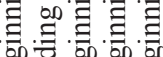

800

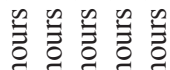

吉吉吉吉

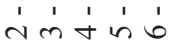

ठ் 

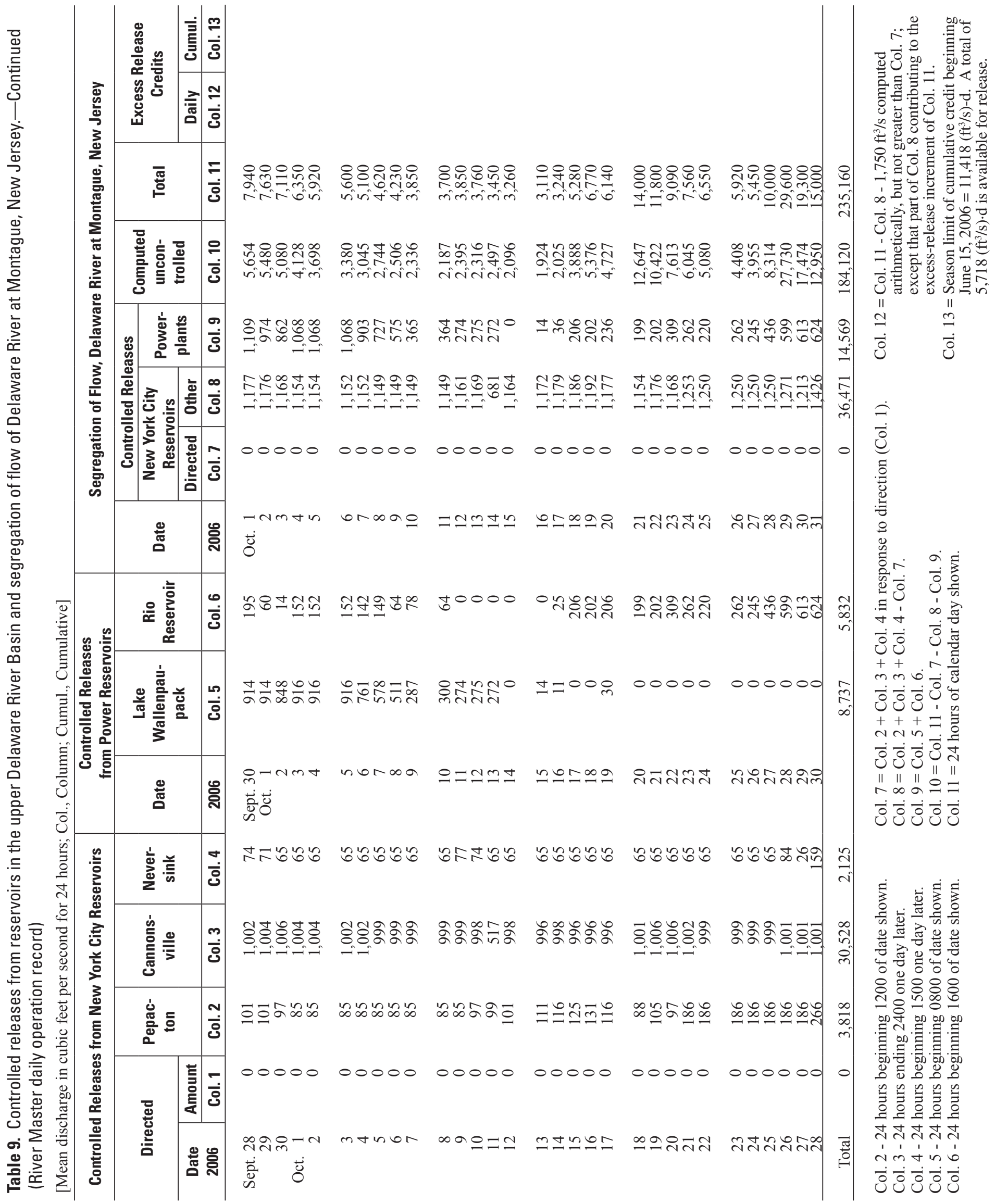

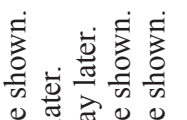
竞 पै त् क्ष 응 88 구의 bo 간 bo bo

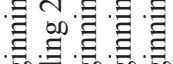
80 諳言言言

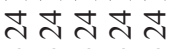

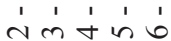
ச் 

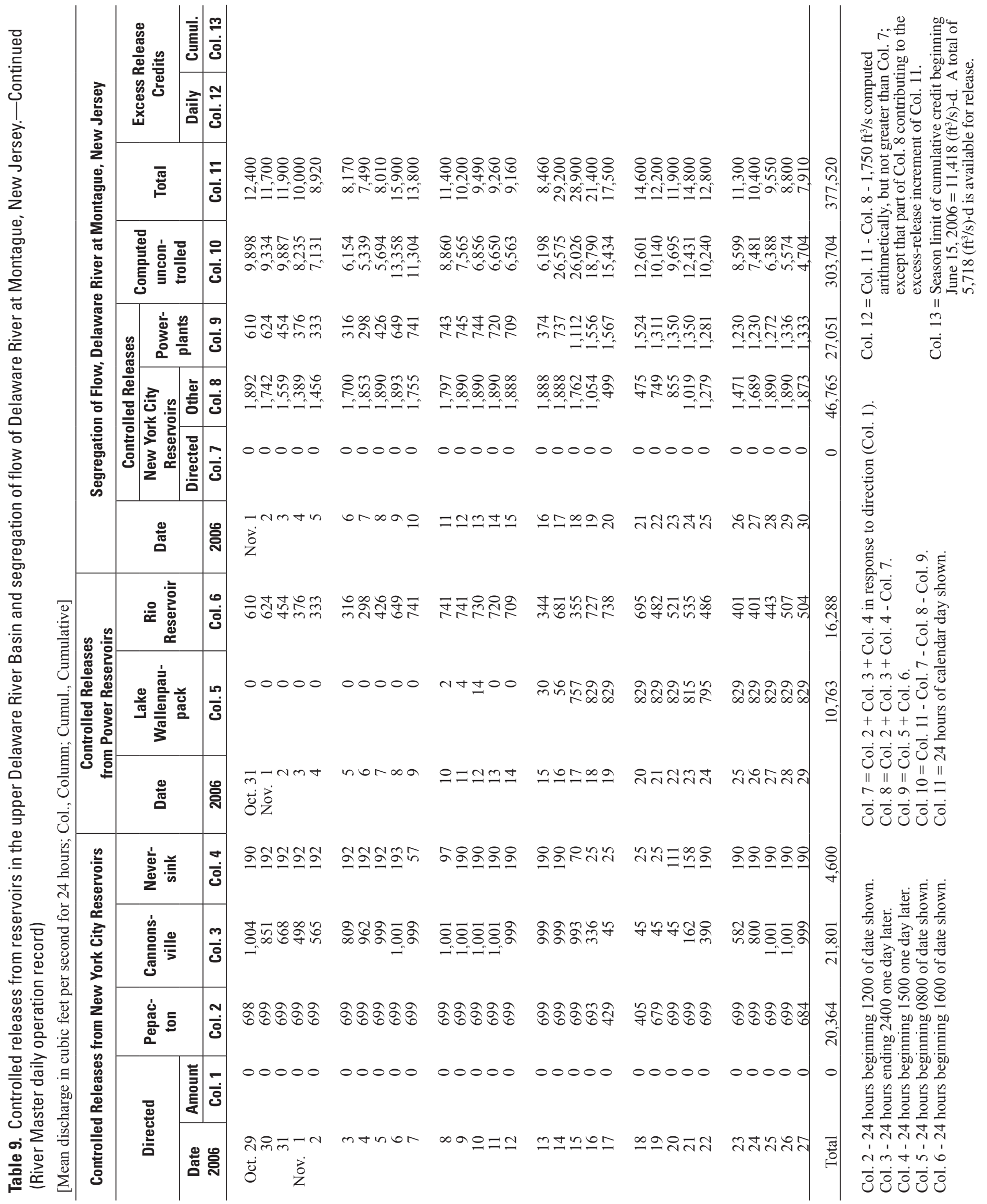

苟官

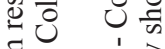

于f $\infty$

ठं

$++r \frac{1}{0}$

mmo $-\pi$

ப் 0 ठல

$+++1=$ N N n ․․ㅇ

0 ن

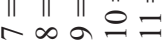

ن்

产苛言产

흥

要焉专要

응ㅇㅇㅇ

궁능ㅇㅇ

on

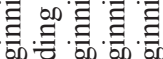

80.080

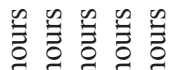

吉吉吉吉

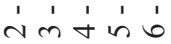

ठ் 


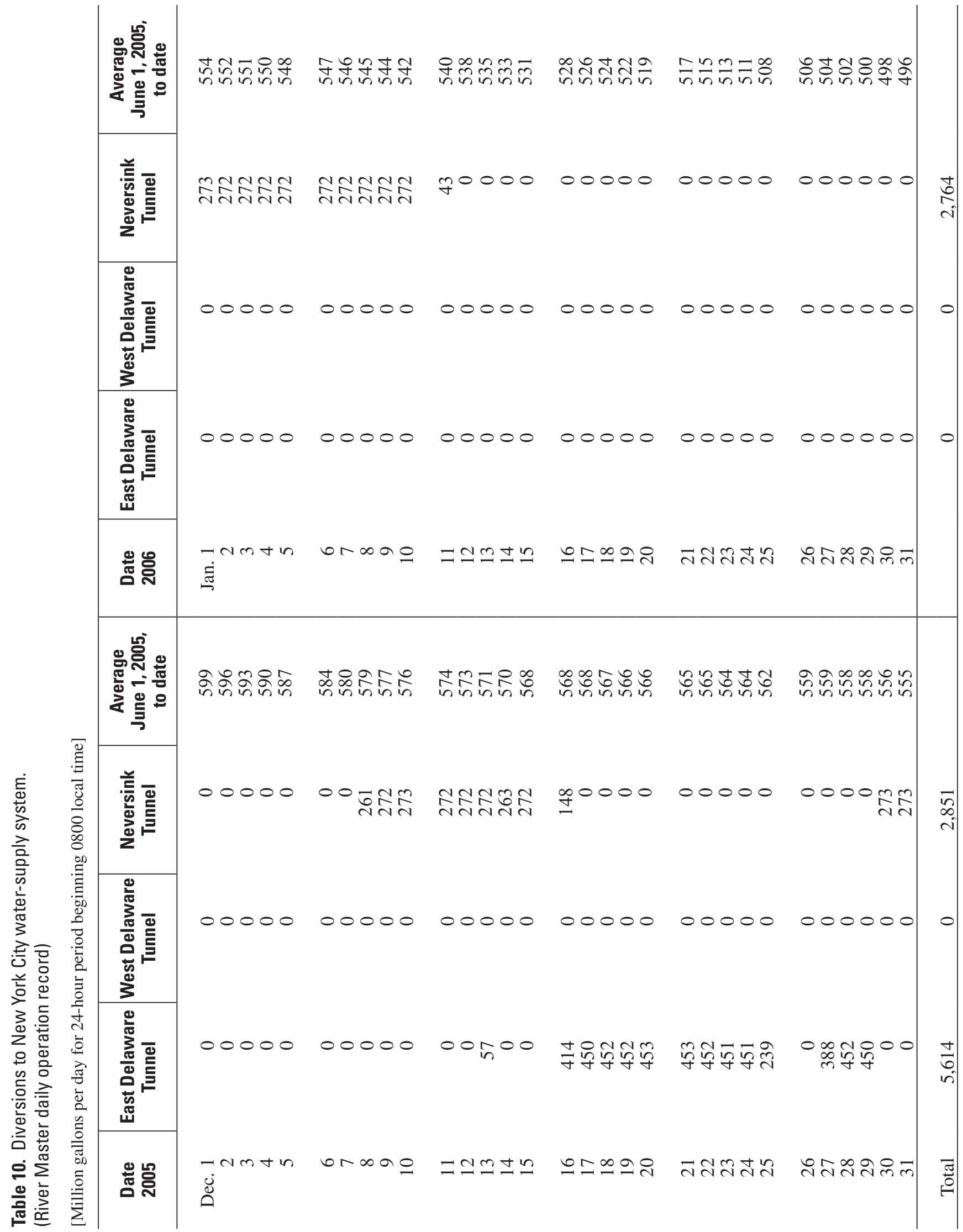




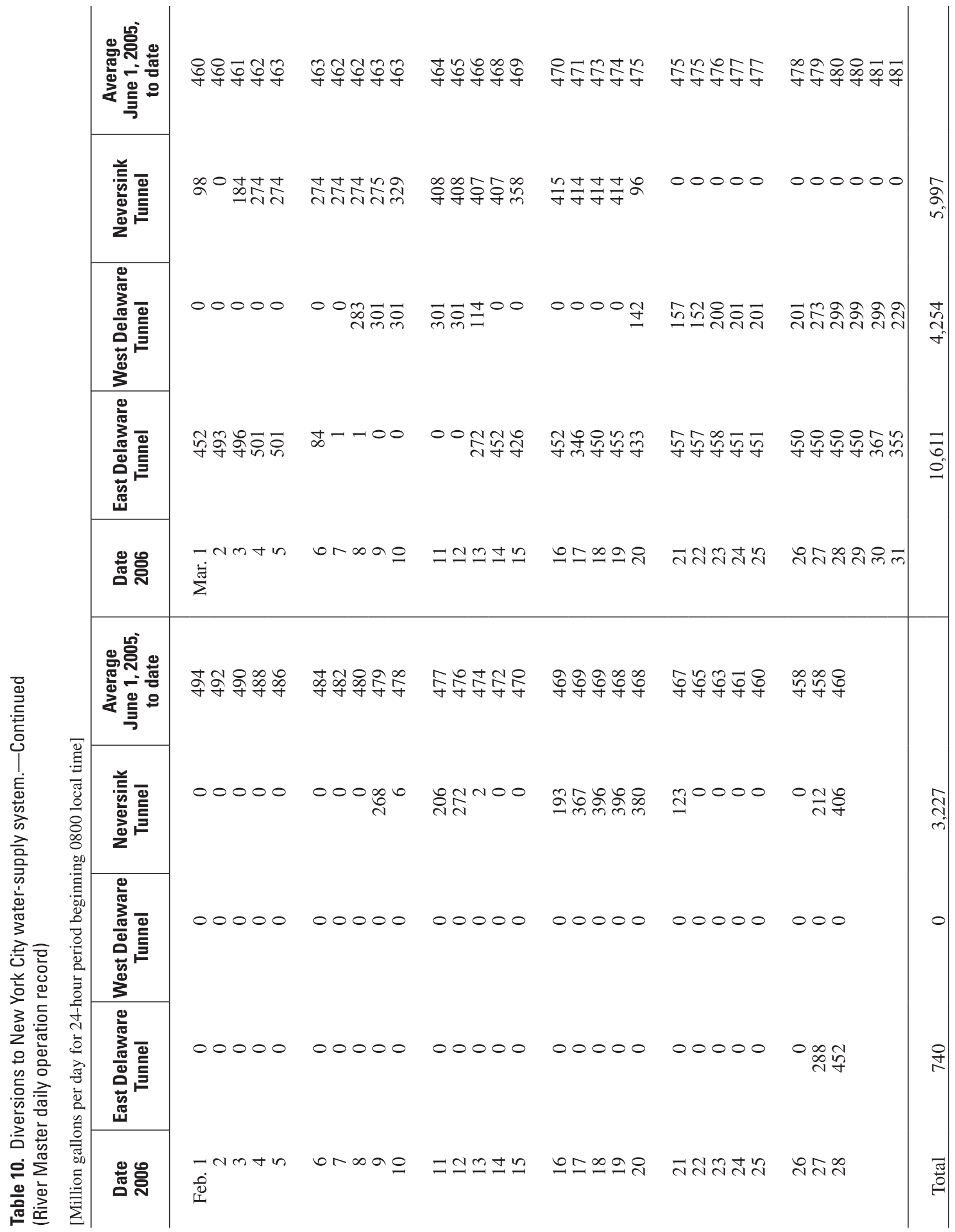




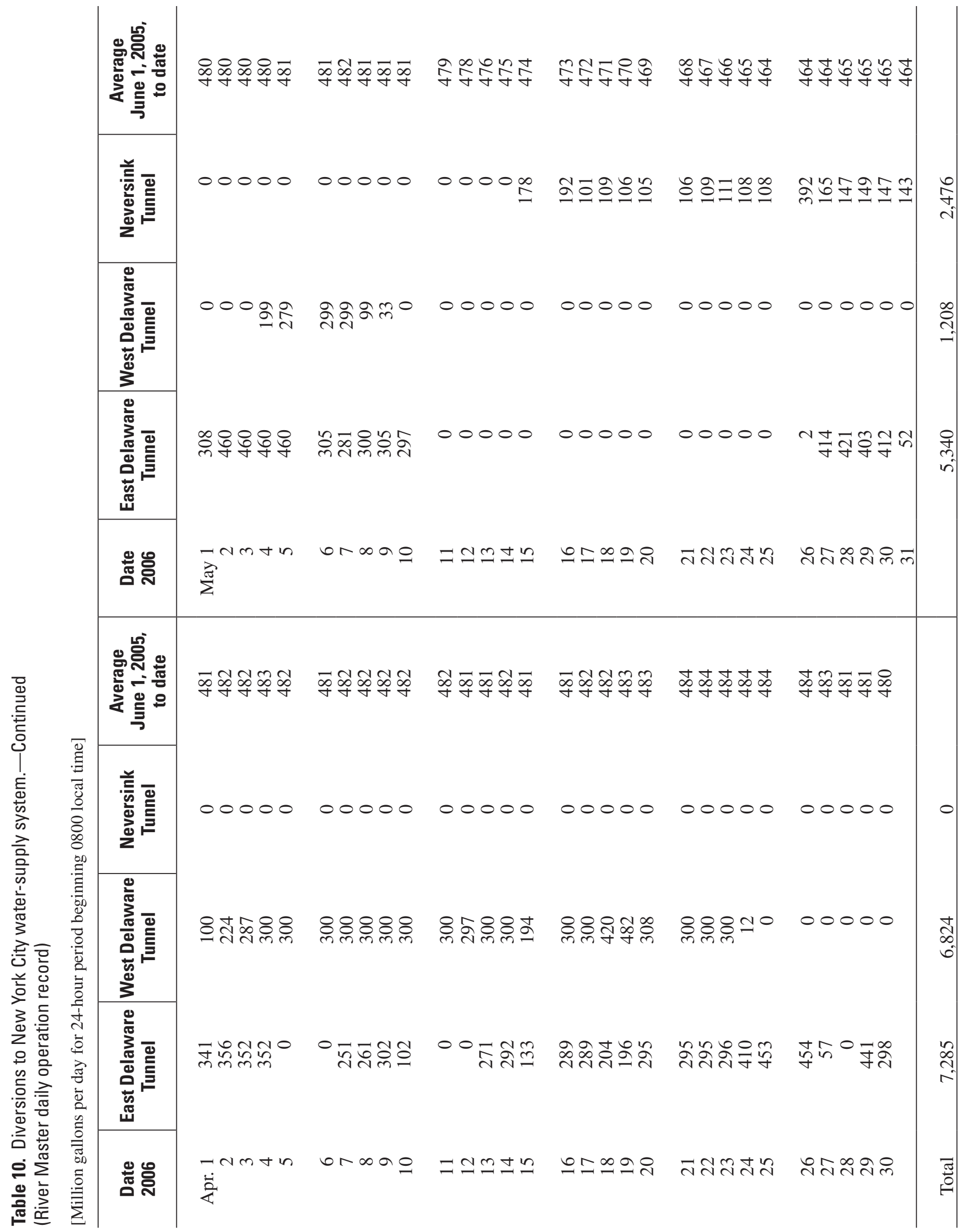




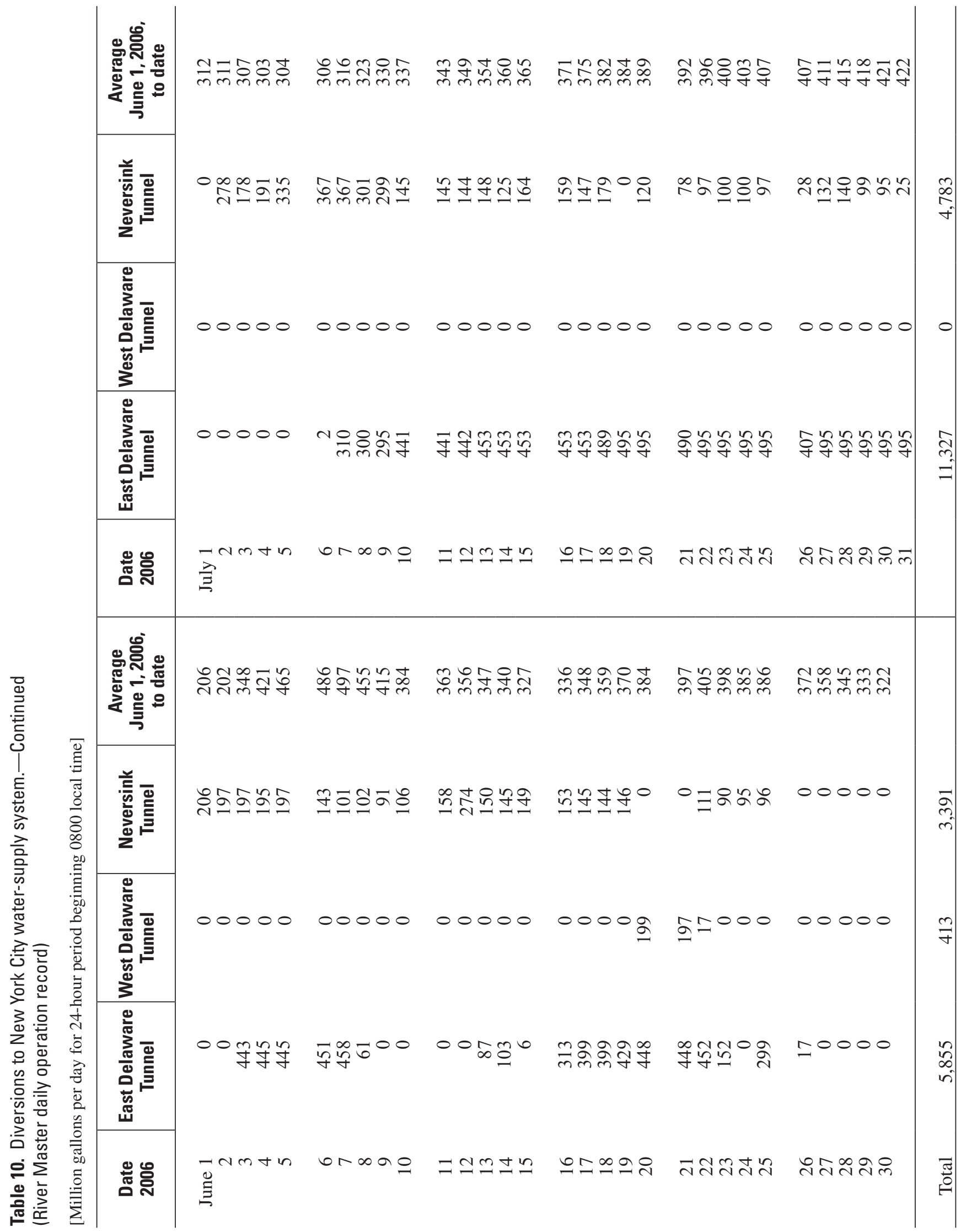




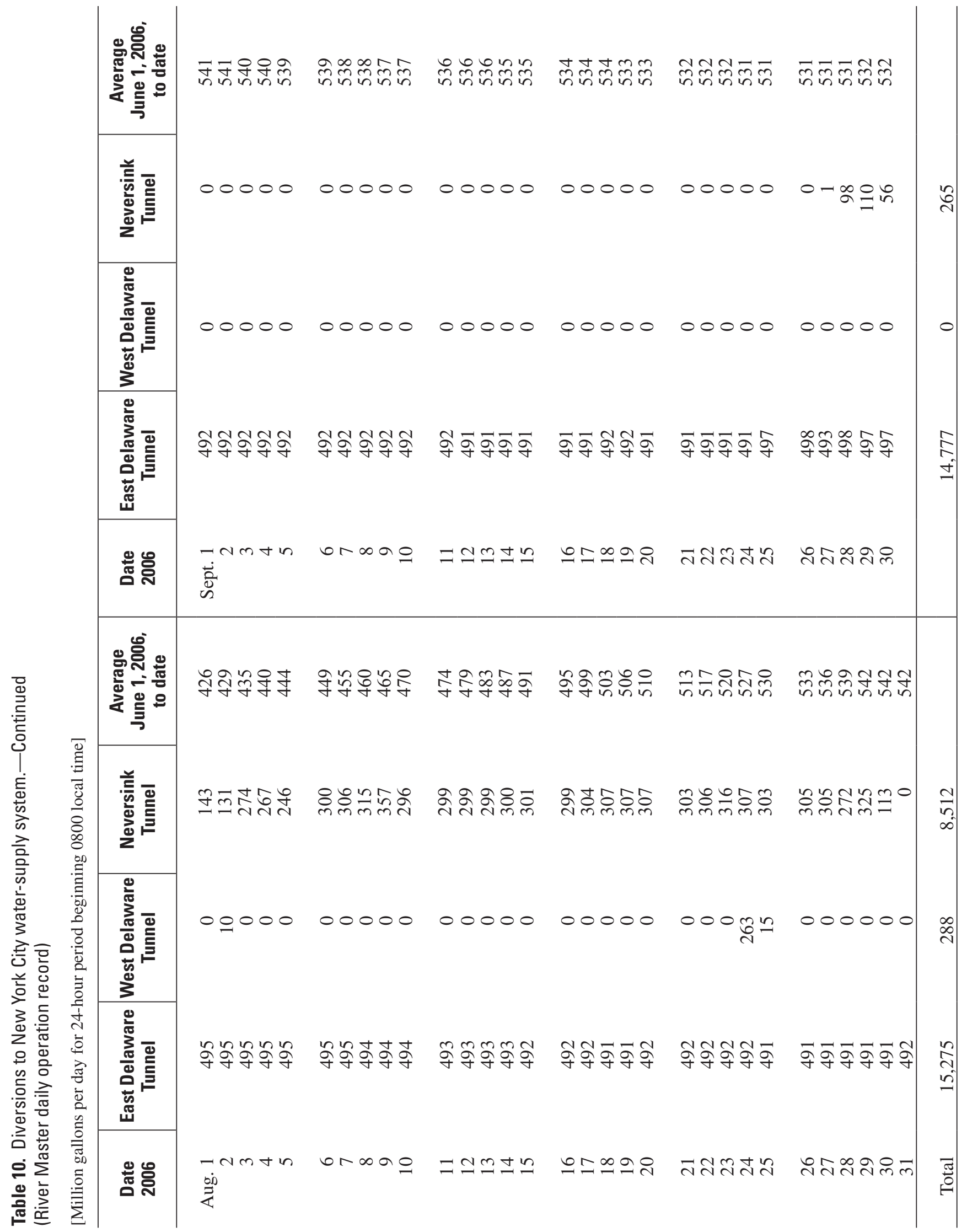




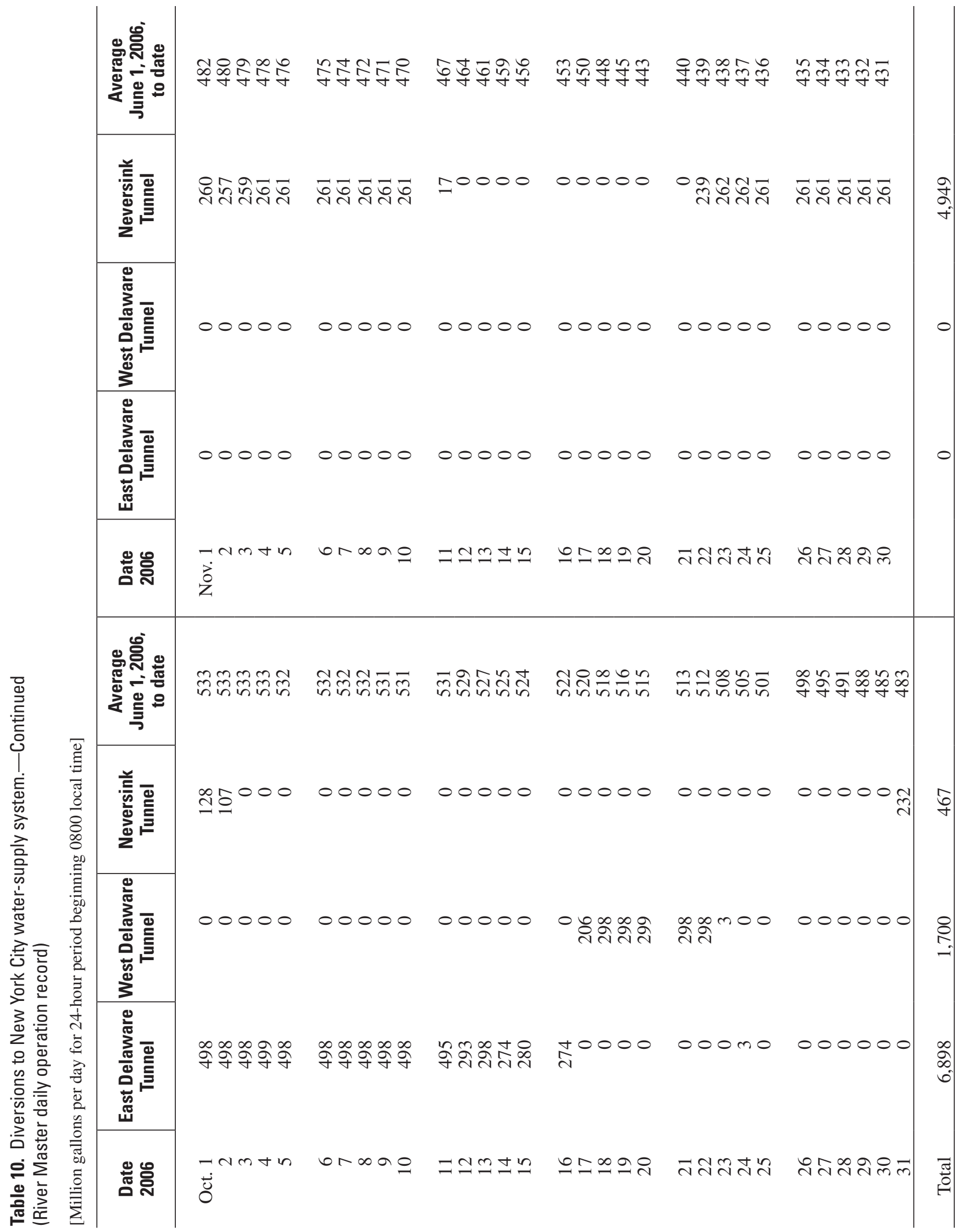




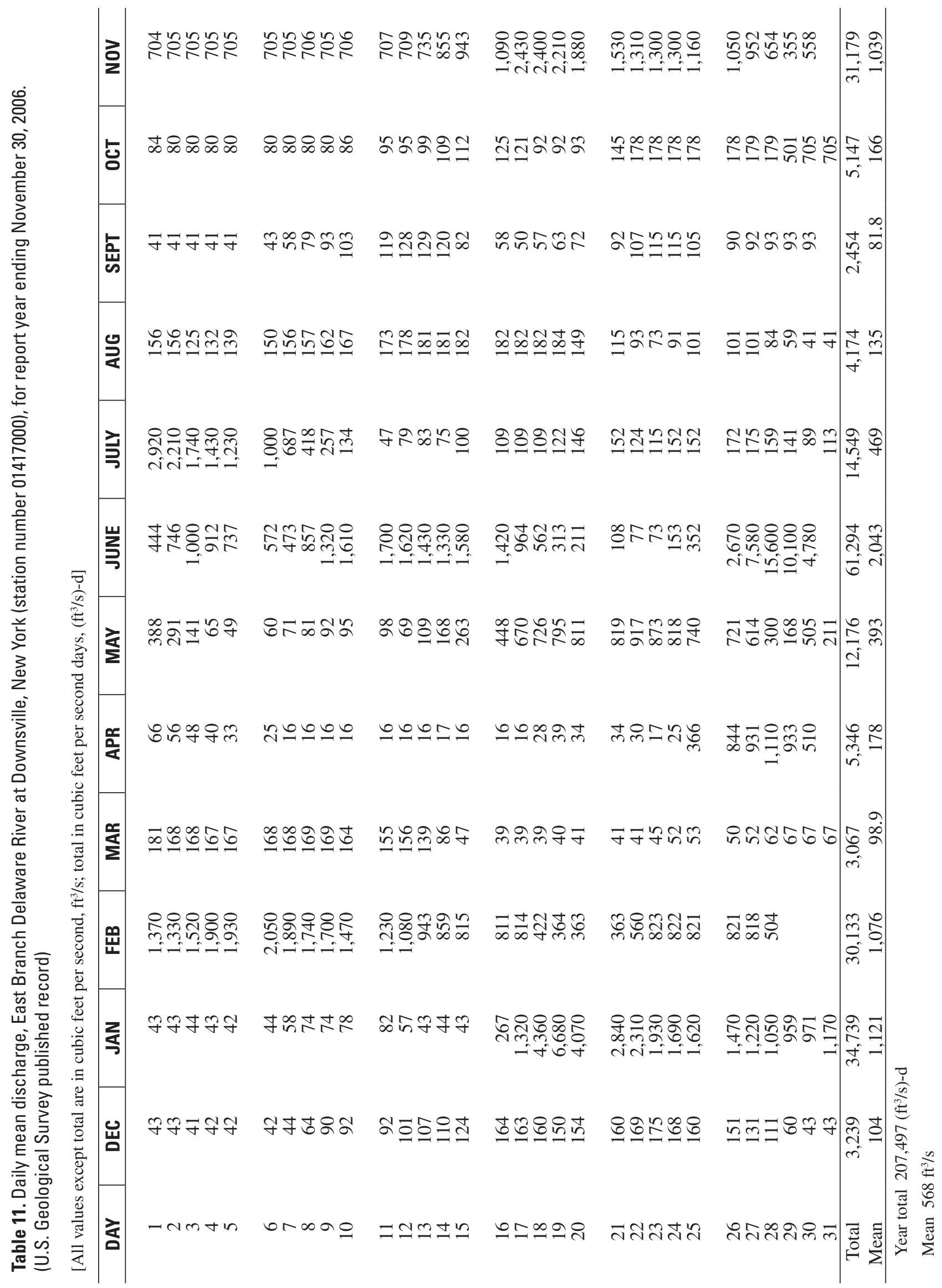




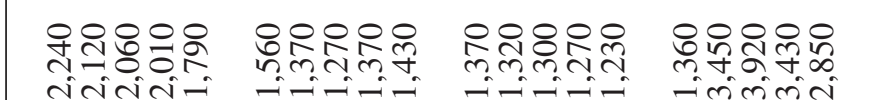
तततत

능

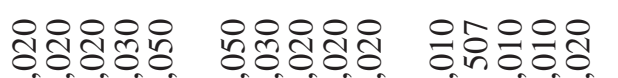
-1-1-i-1-i-i 능요용 윤ํำ ทุำ 으윯유유.

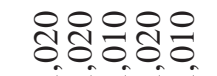

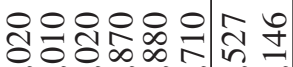
i-i-inini-

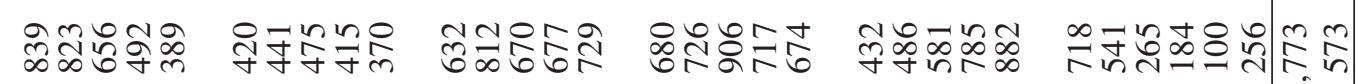

우유으유요

88000 tricio $\therefore \infty \frac{m}{6 \infty} \stackrel{0}{0}$

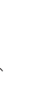

우유ํำ in=-in

ㄱํำ称웡

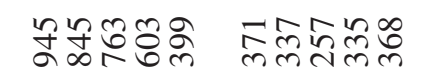

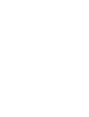
=

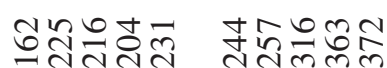

요요 ํํํํํํํำ

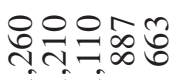

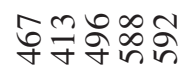

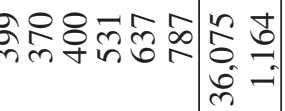

유ำํํำ

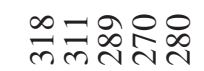

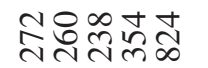

워슊ํㅠ용

ถูำำำ

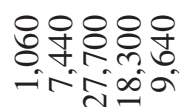

ถู

앙ㅇㅇㅇㅠ

ininiti

\section{유주유} inino

암워융

시에윰ำ

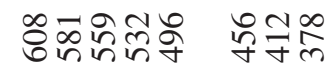

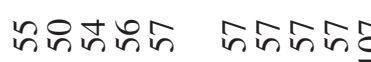
i-i-i

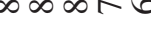

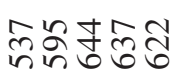

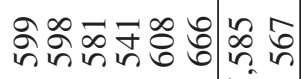
工

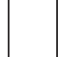

$\sin 2$

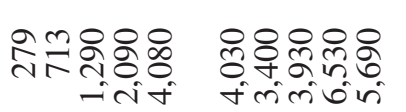

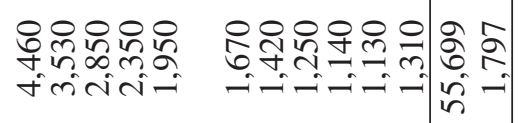

ロ文ทำ

ஃ๘ஃ゚゚

สำชัส

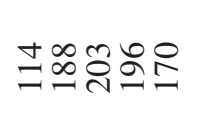

主

- nmtin

orma요

ニッさュ

으으으

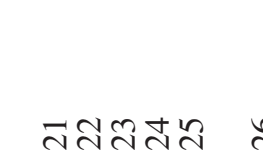

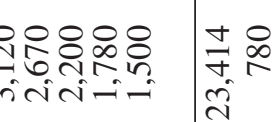

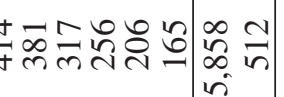

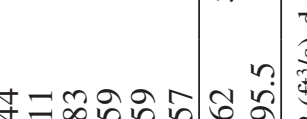




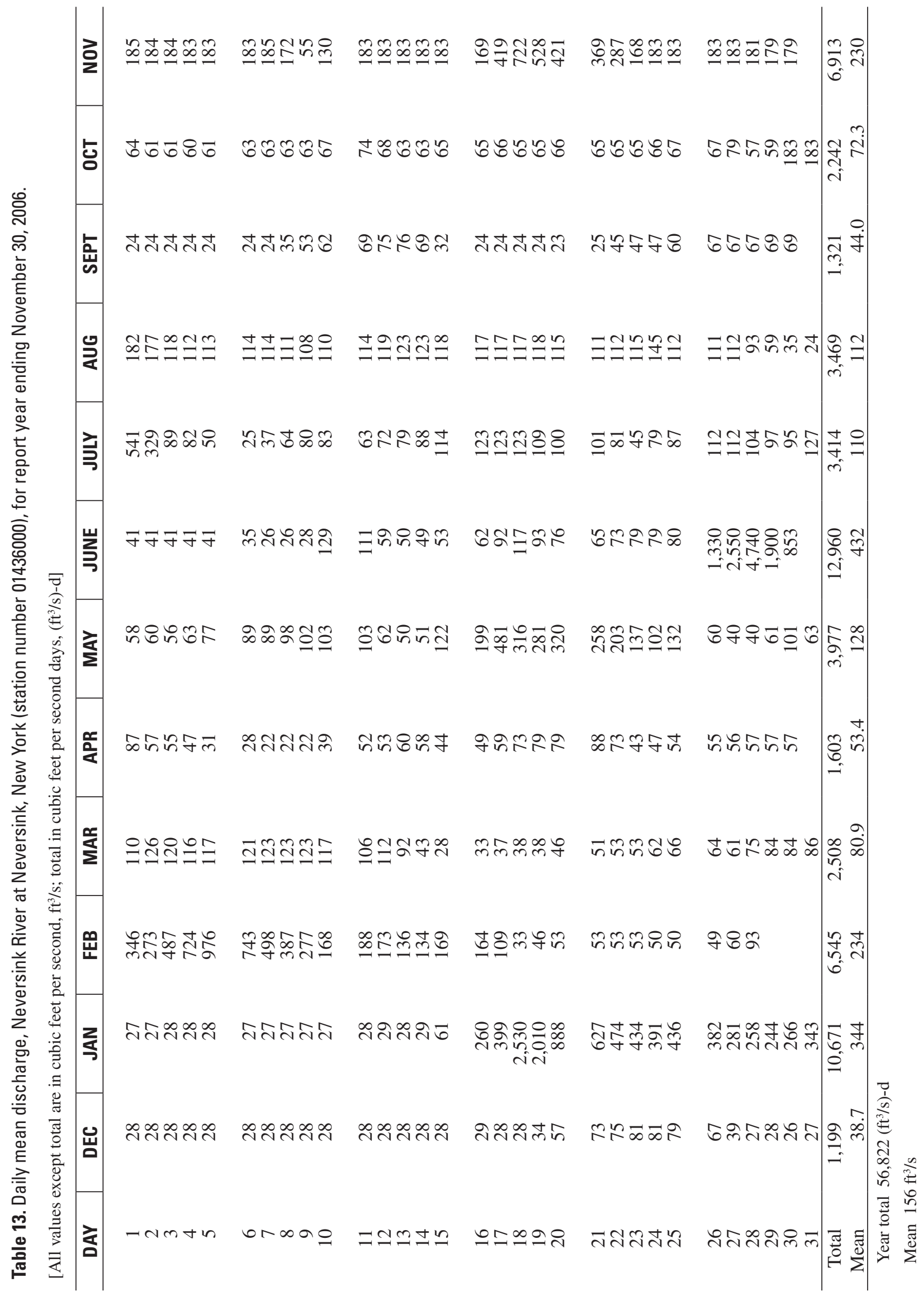




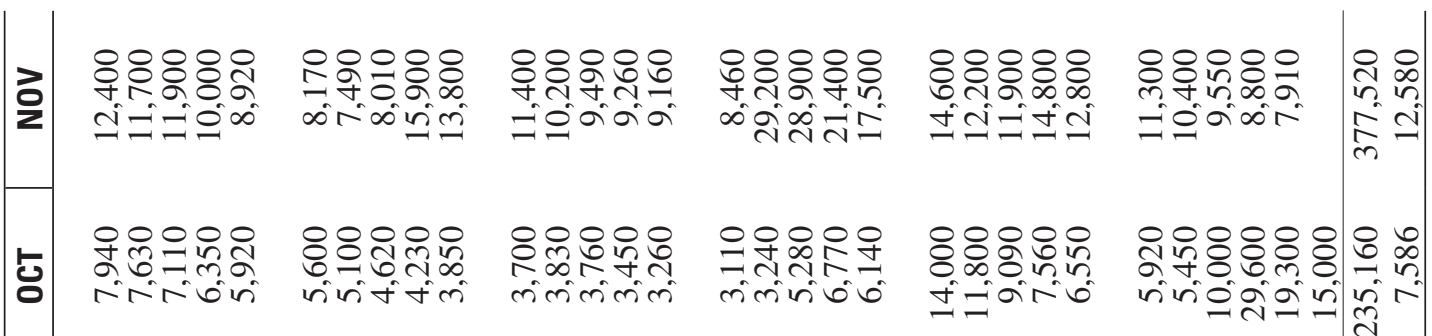

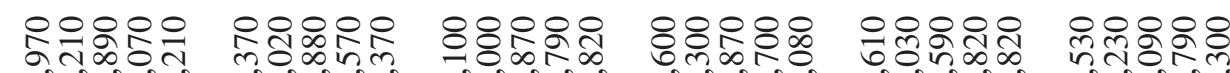

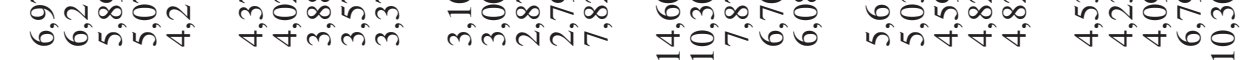

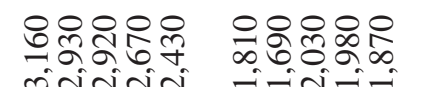

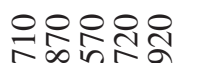

능응융응

옹유:

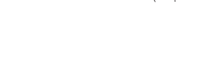

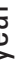

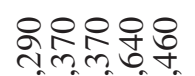

어요웡유

तivici-

inititi-

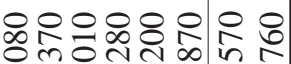
inmingon

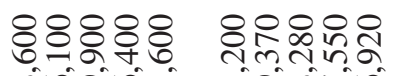

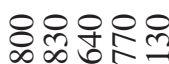
nitr子文子

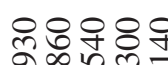

o जंलिलि

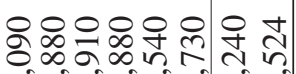

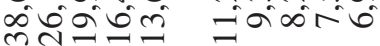
rivinitín rionosin riñó

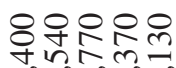

유규중 riminic

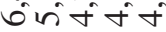

mimmi

जतंतात ली

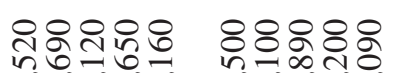

응ํำ minión

은유유유 तीन

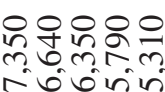
onivitit miminim

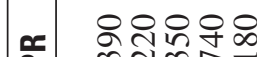

영요

구유:88

minin

유융ㅇ

inivin जiतinल

앙원웡융응

앙ㅇㅇㅇㅇㅇ ninitin

이융ㅇㅇㅇ영

88088

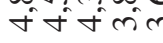

minimini

৪৪৪৪:

งinछ

요

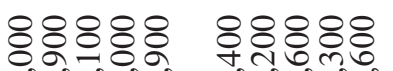
ज讷-i

त่องท

앙유영

4m.

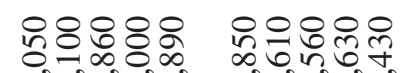

in-

ホヂザナー

$8: 08$

은유워

inoon

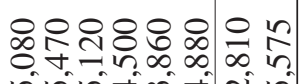

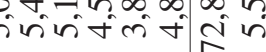

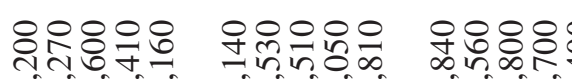

\ =00000

ontovin

vio $= \pm \pm ٔ m$

\&্워융

तiỡin

8용ㅇำ

केंainin

이ㅇㅠㅠ:

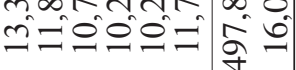

개용유유

애융응 mंचुलm

율유으응 भin

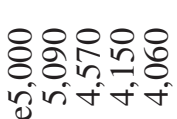

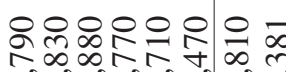

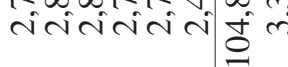

สสกรับ

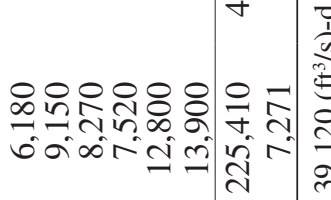




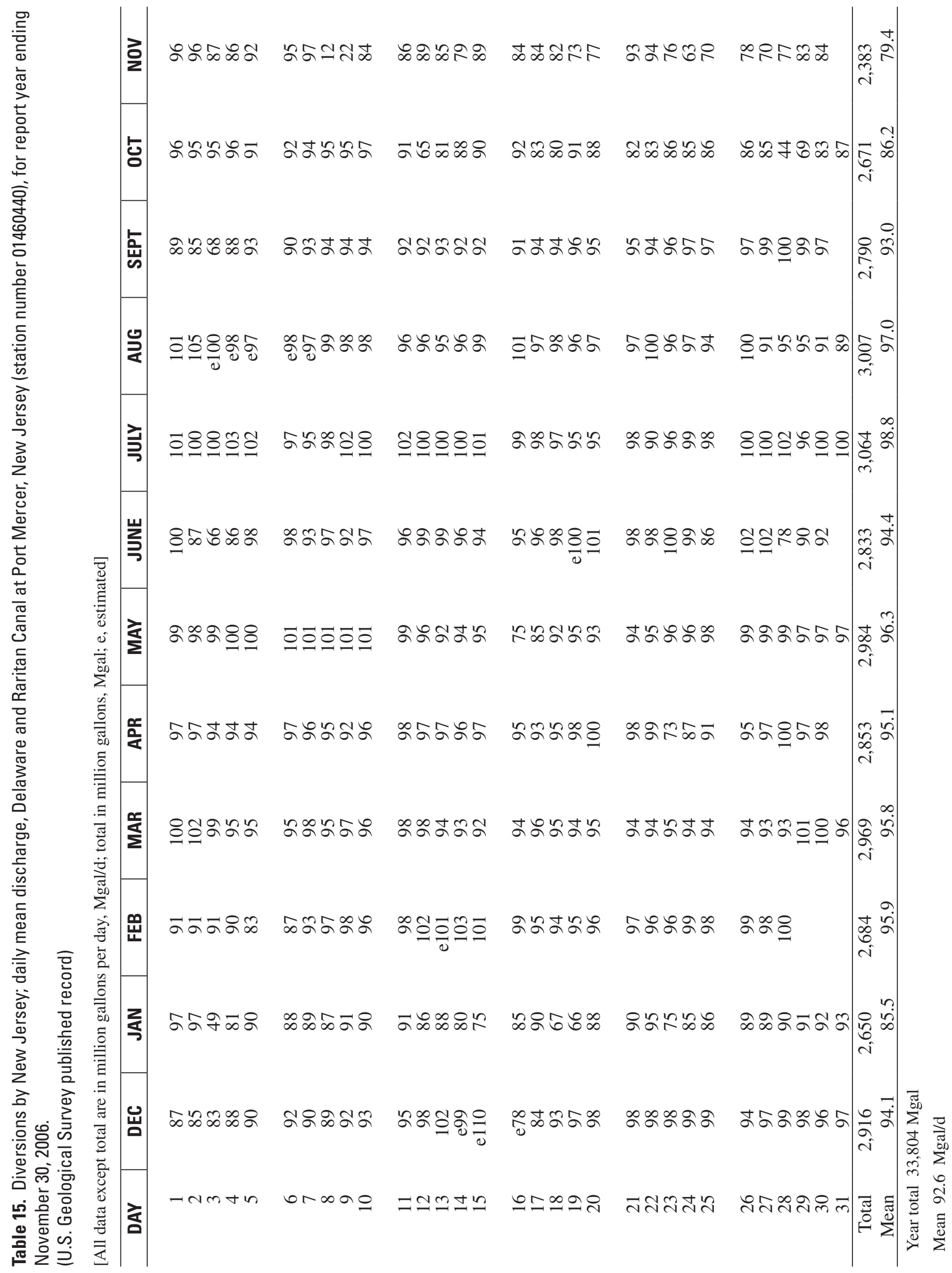




\section{QUALITY OF WATER IN THE DELAWARE ESTUARY}

\section{Introduction}

This section describes the water-quality monitoring program for the Delaware Estuary during the River Master 2006 report year, December 1, 2005, to November 30, 2006. This program is conducted by the USGS, in cooperation with the DRBC. Selected data collected for this program are presented and waterquality conditions are summarized. The DRBC and others use these data to assess water-quality conditions and track the movement of the "salt front" in the Delaware Estuary.

\section{Water-Quality Monitoring Program}

As part of a long-term program, the quality of water in the Delaware Estuary between Trenton, New Jersey, and Reedy Island Jetty, Delaware, is monitored at various locations (fig. 6). Data on water temperature, specific conductance, dissolved oxygen, and $\mathrm{pH}$ were collected by electronic instruments at four sites-Trenton, Benjamin Franklin Bridge (Philadelphia), Chester, and Reedy Island Jetty. Water-quality monitors at Trenton and Reedy Island Jetty were operated continuously throughout the report year, whereas monitors at the Benjamin Franklin Bridge and Chester were operated from April to November 2006.

The frequency of water-quality sampling was monthly in March, June, July, and October, and twice monthly in April, May, August, and September 2006. Water samples at 19 sites between Biles Channel and Mahon River (sample sites A-T on fig. 6) were collected and analyzed by the State of Delaware for the DRBC. At each of these sites, water samples were collected near the center of the channel at a depth of 3 feet below the water surface and analyzed for selected physical properties and chemical constituents including, but not limited to, water temperature, chloride, alkalinity, specific conductance, dissolved oxygen, $\mathrm{pH}$, selected nutrients, and trace metals. These analyses consist of field measurements and laboratory determinations.

From March to October, but excluding June, water-quality samples were collected on a once-monthly basis at three additional sites in the lower Delaware Bay (sites U-W on fig. 6) and analyzed for selected physical properties and chemical constituents.

Data obtained from the electronic water-quality monitors are processed and stored in the USGS National Water Information System database. These data are published annually by the USGS in water resources data reports for New Jersey and Pennsylvania. Water-quality data for the other sampling sites are not presented in this report but are available from DRBC and STORET, an environmental quality database operated by the U.S. Environmental Protection Agency.

\section{Water Quality During the 2006 Report Year}

\section{Streamflow}

Streamflow has a major effect on the quality of water in the Delaware Estuary. High freshwater inflows commonly result in improved water quality by limiting the upstream movement of seawater and reducing the concentration of dissolved substances. High inflows also aid in maintaining lower water 


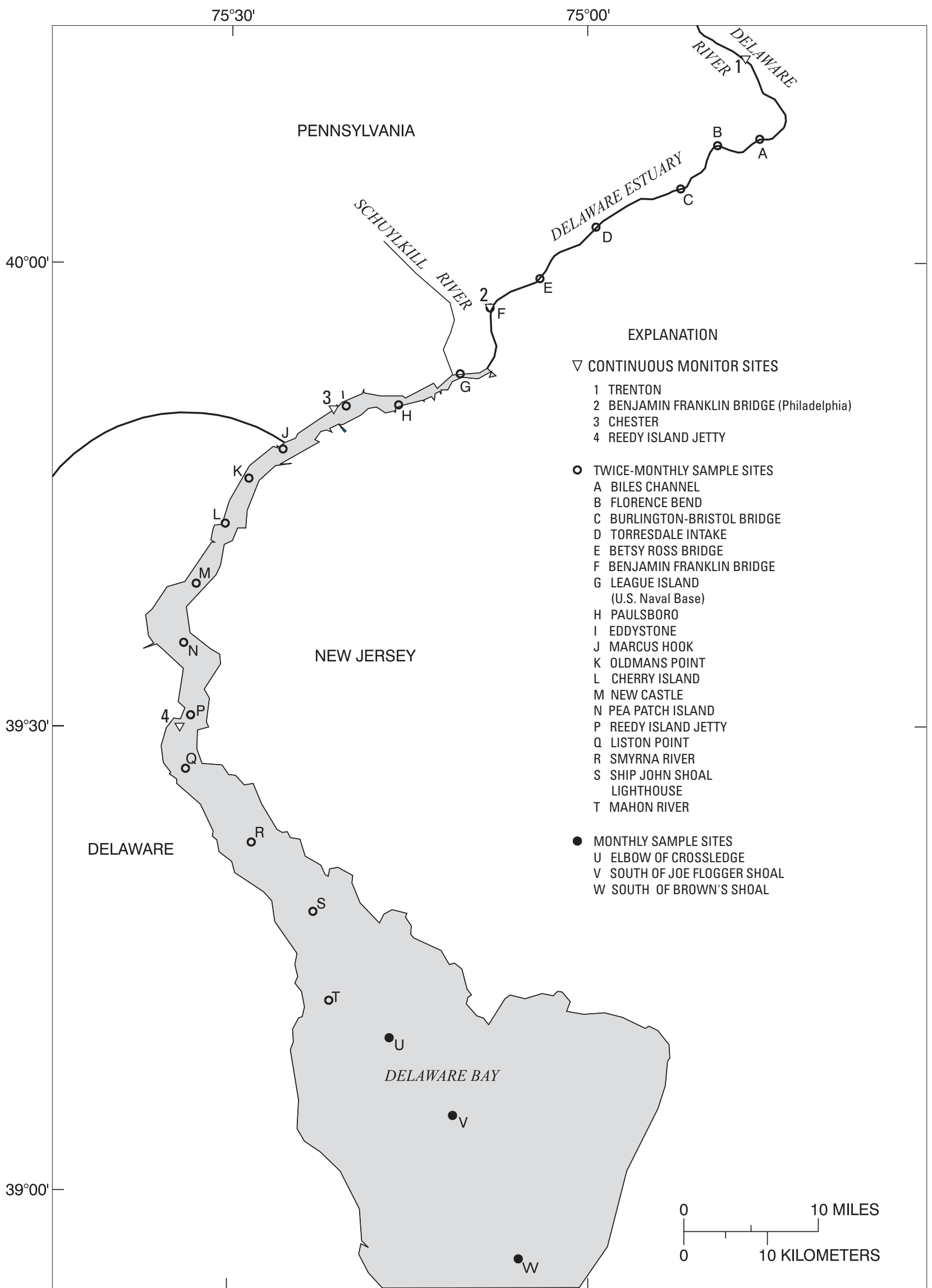

Figure 6. Location of water-quality monitoring sites on the Delaware Estuary. 
temperatures during warm weather and in supporting higher concentrations of dissolved oxygen. Under certain conditions, however, high streamflows can transport large quantities of nutrients to the estuary, which may result in excessive levels of algae.

Streamflow from the Delaware River Basin upstream of Trenton, New Jersey, is the major source of freshwater inflow to the Delaware Estuary. During the report year, monthly mean streamflow measured at the USGS gaging station Delaware River at Trenton, New Jersey, was highest during January 2006 $\left(31,770 \mathrm{ft}^{3} / \mathrm{s}\right)$ and lowest during August $2006\left(5,644 \mathrm{ft}^{3} / \mathrm{s}\right.$; table 16) ${ }^{2}$. Monthly mean streamflows were less than long-term mean monthly flows in March, April, May, and August and greater than the long-term flows in the other eight months. The greatest flow deficiency was in March 2006, when monthly mean streamflow was 38 percent of the long-term mean monthly flow. Long-term monthly mean streamflow was computed on the basis of data for the period from 1913 to 2005. The highest daily mean streamflow during the report year was $224,000 \mathrm{ft}^{3} / \mathrm{s}$ on June 29,2006 . The lowest daily mean streamflow was $3,850 \mathrm{ft}^{3} / \mathrm{s}$ on August 15, 2006.

\section{Water Temperature}

Water temperature has an important influence on water quality, as it affects various physical, chemical, and biological properties of water. Generally, increases in water temperature have detrimental effects on water quality by decreasing the saturation level of dissolved oxygen and increasing the biological activity of aquatic organisms. Although the primary factors that affect water temperature in the Delaware Estuary are climatic, various kinds of water use, especially powerplant cooling, also can have significant effects.

At the Benjamin Franklin Bridge, Philadelphia, Pennsylvania, water-temperature data were collected continuously from April to November 2006. Monthly mean temperatures were greater than the long-term mean monthly temperatures in April, May, and August 2006 and were less than the long-term means in June, July, and from September to November 2006. Long-term mean water temperatures were computed using data for the period from 1964 to 2005 (fig. 7). The maximum daily mean water temperature of $29.1^{\circ} \mathrm{C}$ was recorded on August 4 and 5, 2006.

\section{Specific Conductance and Chloride}

Specific conductance is a measure of the capacity of water to conduct an electrical current and is a function of the types and quantities of dissolved substances in water. As concentrations of dissolved ions increase, specific conductance of the water also increases. Specific conductance measurements are good indicators of dissolved solids content and total ion concentrations. Seawater and some man-made constituents can cause the specific conductance of estuary water to increase substantially. Dilution associated with high freshwater inflows results in decreased levels of dissolved solids and lower specific conductance whereas low inflows have the opposite effect.

The upstream movement of seawater and the accompanying increase in chloride concentrations is an important concern for water supplies obtained from the Delaware Estuary. Water with chloride concentrations greater than 250 milligrams per liter $(\mathrm{mg} / \mathrm{L})$ is considered undesirable for domestic use, and water with concentrations exceeding $50 \mathrm{mg} / \mathrm{L}$ is unsatisfactory for chemically sensitive consumers and some

${ }^{2}$ All numbered tables in the section "Quality of Water in the Delaware Estuary" are grouped at the end of this section, beginning on page 62 . 


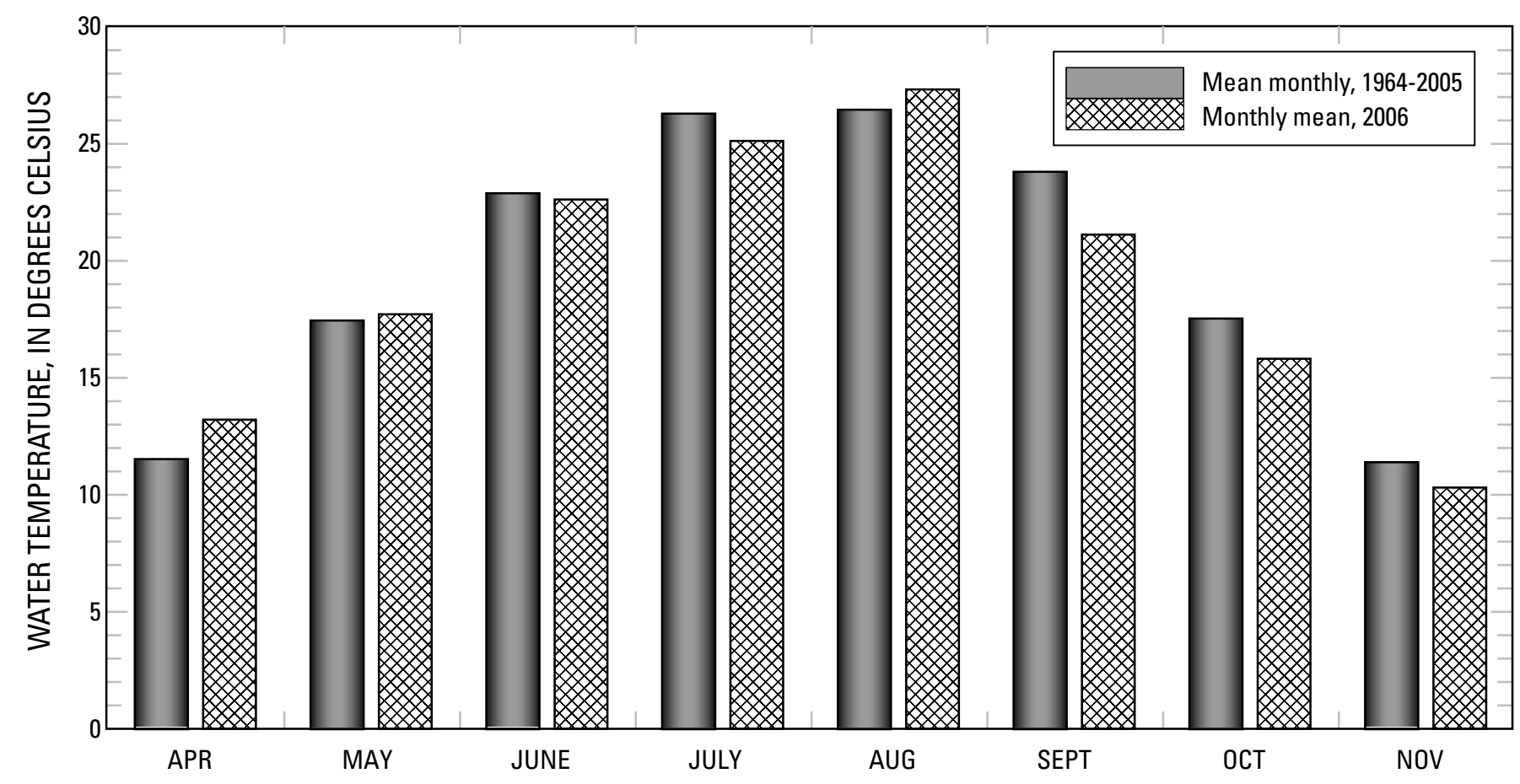

Figure 7. Water temperature in the Delaware Estuary at Benjamin Franklin Bridge at Philadelphia, Pennsylvania, April to November.

industrial processes. Chloride concentrations in the estuary increase in a downstream direction, with increasing proximity to the Atlantic Ocean.

Chloride concentration was not measured directly at the monitor site at Reedy Island Jetty, Delaware. Rather, a mathematical relation between specific conductance and chloride concentration has been developed on the basis of long-term field measurements of specific conductance and laboratory analyses of chloride; this relation was used to estimate chloride concentrations from specific conductance values. Chloride concentrations estimated from the relation are presented in table 17. The specific conductancechloride relation is less reliable when chloride concentrations are less than $30 \mathrm{mg} / \mathrm{L}$, because other chemical substances may be present in quantities large enough to affect the relation. Thus, chloride concentrations estimated from specific conductance data are not presented when concentrations of less than $30 \mathrm{mg} / \mathrm{L}$ result from the relation. Instead, estimated values less than $30 \mathrm{mg} / \mathrm{L}$ are reported as $<30 \mathrm{mg} / \mathrm{L}$. Chloride concentrations at Chester, Pennsylvania (table 18), were measured directly by Kimberly Clark Chester Operations and are not derived from specific conductance data.

At Chester, the greatest daily maximum chloride concentration was $120 \mathrm{mg} / \mathrm{L}$ on August 26-28, 2006 (table 18). During the report year, daily maximum concentrations exceeded $50 \mathrm{mg} / \mathrm{L}$ on 27 percent of the days. The lowest daily minimum chloride concentration was $18 \mathrm{mg} / \mathrm{L}$ on July 1, 2006. Daily minimum concentrations exceeded $50 \mathrm{mg} / \mathrm{L}$ on 17 percent of the days. Chloride concentrations were persistently high from December 19-31, 2005, from April 3-25, 2006, and from August 15 to September 1, 2006, when daily minimum concentrations exceeded $50 \mathrm{mg} / \mathrm{L}$ on most days.

At Reedy Island Jetty, the greatest daily maximum chloride concentration was 7,100 mg/L on September 2, 2006 (table 17). Daily maximum chloride concentrations during the report year exceeded $1,000 \mathrm{mg} / \mathrm{L}$ on 93 percent of the days. The lowest daily minimum chloride concentration was $<30 \mathrm{mg} / \mathrm{L}$ on several days in each of the following months: January, June, and July 2006. Daily minimum chloride 
concentrations exceeded 1,000 mg/L on 52 percent of the days. From December to May, daily maximum chloride concentrations at Reedy Island Jetty ranged from 33 to 6,900 mg/L. From June to November, daily maximum chloride concentrations ranged from 45 to $7,100 \mathrm{mg} / \mathrm{L}$.

\section{Dissolved Oxygen}

Dissolved oxygen in water is necessary for the respiratory processes of aquatic organisms and for chemical reactions in aquatic environments. Fish and many other clean-water species require relatively high dissolved-oxygen concentrations at all times. The major source of dissolved oxygen in the Delaware Estuary is diffusion from the atmosphere, and, to a lesser extent, photosynthetic activity of aquatic plants. The principal factors that affect dissolved-oxygen concentrations in the estuary are water temperature, biochemical oxygen demand, freshwater inflow, phytoplankton, turbidity, salinity, and tidal and wind-driven mixing.

Concentrations of dissolved oxygen at several sites on the Delaware Estuary have been measured since 1962 by the USGS. Two of these sites, Delaware River at Benjamin Franklin Bridge at Philadelphia, Pennsylvania, and Delaware River at Chester, Pennsylvania, have nearly continuous records and are in the reach of the estuary most affected by effluent discharges. The mean, and minimum daily mean, dissolved-oxygen concentrations from July to September at these station during the 1965-2006 report years are shown in figure 8. Although concentrations have increased considerably over this 42 -year period, mean concentrations can vary considerably from year to year.

Concentrations of dissolved oxygen in the Delaware Estuary generally are greatest near Trenton and decrease in a downstream direction. In an area just downstream of the Benjamin Franklin Bridge, concentrations commonly reach minimum levels. During the report year, daily mean concentrations of dissolved oxygen at the Benjamin Franklin Bridge monitor site were lowest in late August, and the lowest recorded daily mean concentration was $3.7 \mathrm{mg} / \mathrm{L}$ on August 30 (table 19). Daily mean concentrations of dissolved oxygen were consistently $6.0 \mathrm{mg} / \mathrm{L}$ or greater on all days from April 1 to June 3; June 30 to July 15; September 3-6; and September 18 to November 30, 2006. At Chester, daily mean dissolved-oxygen concentrations were lowest during mid- to late June, late July, and early August, and the lowest recorded daily mean concentration was $4.6 \mathrm{mg} / \mathrm{L}$ on various dates in June, July, and August 2006 (table 20).

Histograms of hourly dissolved-oxygen concentrations at the Benjamin Franklin Bridge and Chester monitor sites during the critical summer period-July to September 2006 - are presented in figure 9. Hourly concentrations at the Benjamin Franklin Bridge were $4 \mathrm{mg} / \mathrm{L}$ or less during about 18 percent of this

period. At Chester, hourly dissolved-oxygen concentrations were $4 \mathrm{mg} / \mathrm{L}$ or less during 0.64 percent of the 2006 critical summer period. Dissolved-oxygen concentrations less than $4 \mathrm{mg} / \mathrm{L}$ can have adverse, and possibly lethal, effects on fish and other aquatic organisms. 


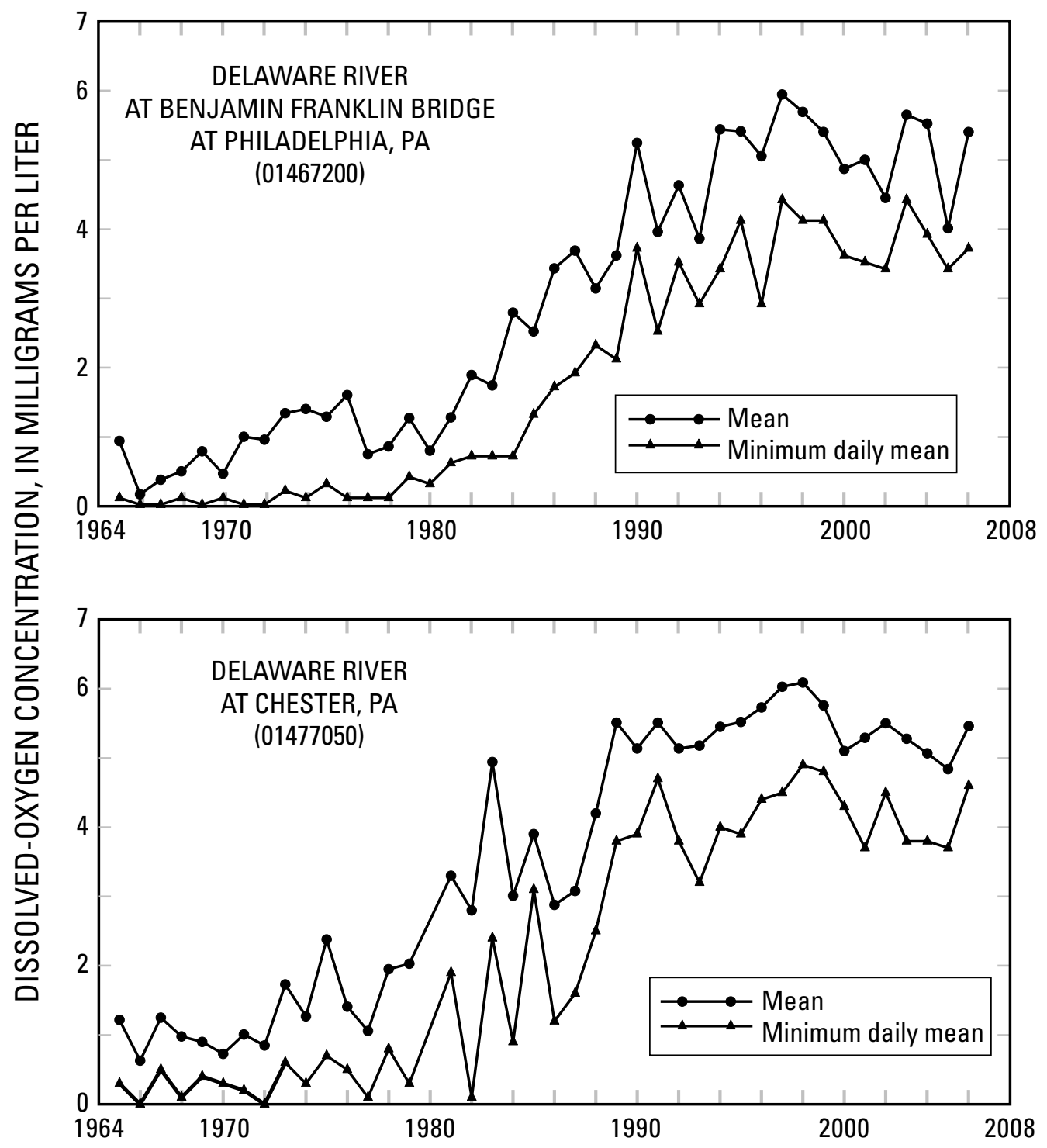

Figure 8. Mean and minimum daily mean dissolved-oxygen concentrations from July to September at two monitor sites on the Delaware Estuary, 1965-2006. 


\section{Hydrogen-Ion Activity (pH)}

The $\mathrm{pH}$ of a solution is a measure of the effective concentration (activity) of dissolved hydrogen ions. Solutions having $\mathrm{pH}$ less than 7 are characterized as acidic, whereas solutions with $\mathrm{pH}$ greater than 7 are considered basic or alkaline. The $\mathrm{pH}$ of uncontaminated surface water generally ranges from 6.5 to 8.5. Major factors affecting the $\mathrm{pH}$ of surface water include the geologic composition of the drainage basin and human inputs, including effluent discharges. In addition, photosynthetic activity, and dissolved gases including carbon dioxide, hydrogen sulfide, and ammonia can have a considerable effect on pH. During the report year, $\mathrm{pH}$ was measured seasonally at the Benjamin Franklin Bridge and Chester monitor sites, and continuously at the Reedy Island Jetty site. During these periods, the ranges of daily median $\mathrm{pH}$ measured at these stations were as follows: Benjamin Franklin Bridge, 6.3 to 7.6; Chester, 6.9 to 7.5; and Reedy Island Jetty, 6.9 to 8.2. Generally, the $\mathrm{pH}$ of water in the Delaware Estuary is lowest near Trenton, New Jersey, and increases (that is, water becomes more alkaline) in a downstream direction. The $\mathrm{pH}$ of water in the Delaware Estuary between the Benjamin Franklin Bridge and Reedy Island Jetty is not a limiting factor for aquatic health or other beneficial uses of the water.

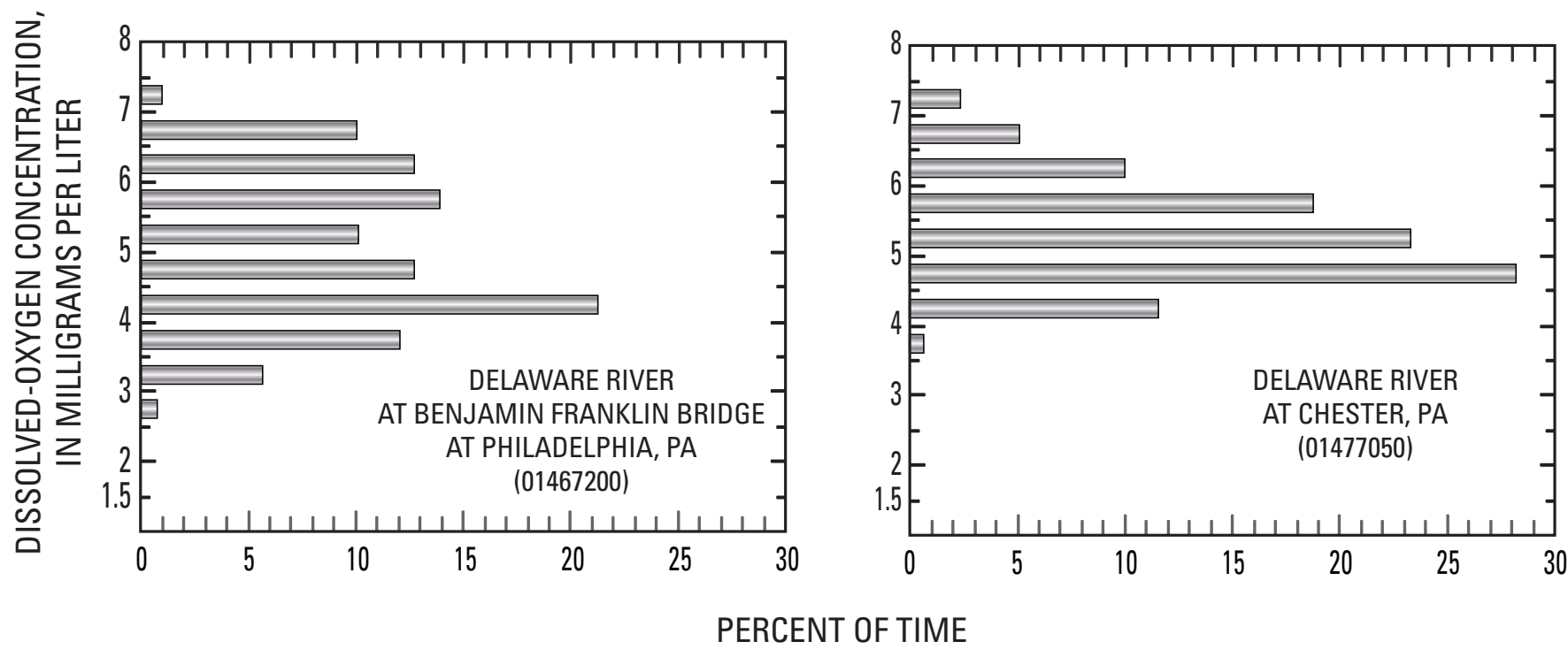

Figure 9. Distribution of hourly dissolved-oxygen concentrations at two monitor sites on the Delaware Estuary, July to September 2006. 


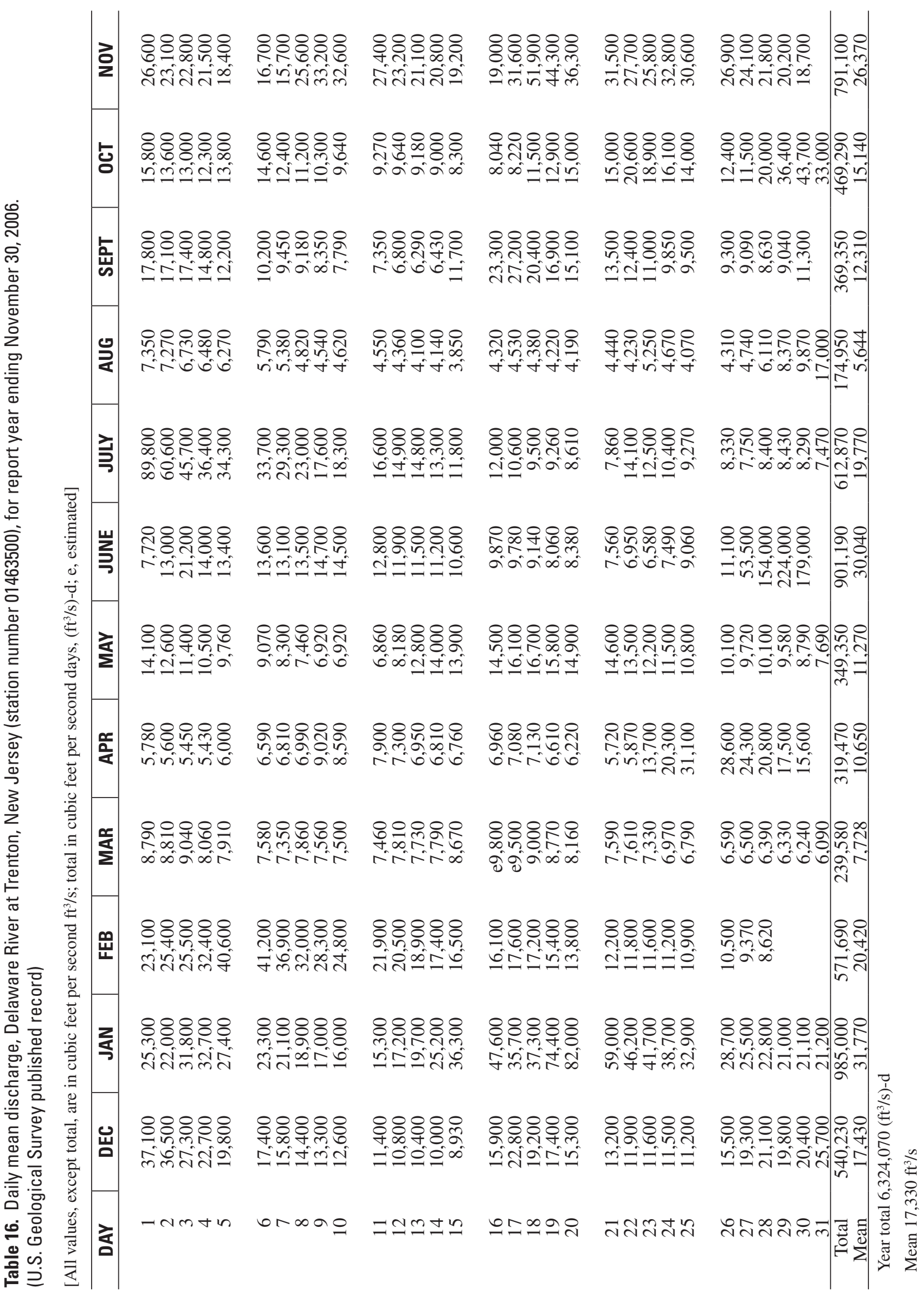




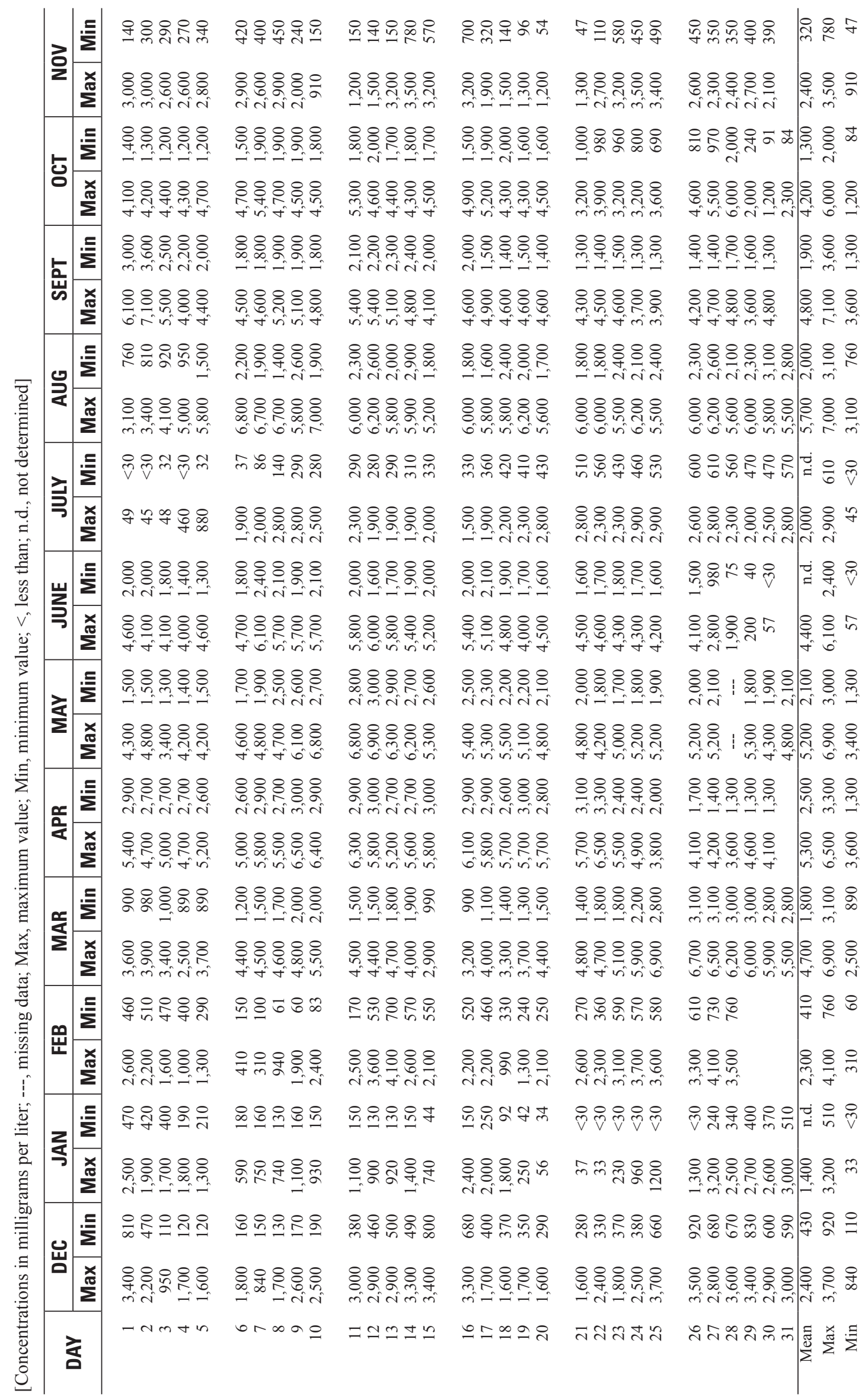


- $\operatorname{minh}$

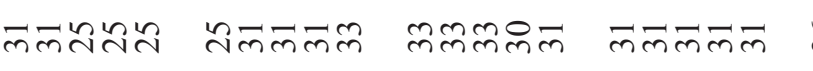

ヴゥラッ

๓ோக்

लूलून

$\infty \infty \infty \infty \infty$

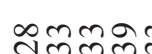

mळmmm

맡유가

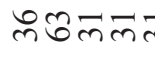

๓ேேேோ

กีู่่

শiণ 00

igaro

mnmmm

लmmलm

パスேோ

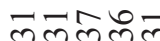

๓ิЕन

бiminin

$\infty \infty \infty+$

$\infty 0060$

लूलेलेल

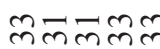

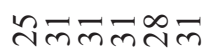

तี ले ते

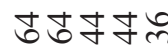

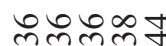

유유유

तกํำत

लूलिलm

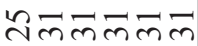

mกn

สีสีกั

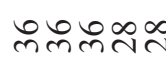

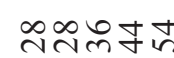

miner

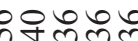

꾺ำ

ตேㅇํ

수슈

이유유

$\stackrel{\sim}{\infty} \infty$ 남

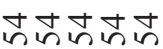

僻导过

수숫ำ

$\infty \underset{m}{\mathbb{i}}$

๑สสกต

तิल๗लmल

mmmत

สกสกก

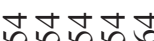

tititio

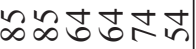

$\infty \infty$

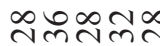

mmmmm

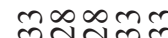

ㅊํํํํำ

สีสพฺ

ㅇํํํำ

inำำ

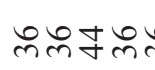

$\stackrel{\sim}{\infty} \infty \infty \infty \infty$

$\stackrel{\sim}{\infty} \infty \infty \infty \infty$

mलmत्

이요

ํํํํำ

ํㅜㅆ

लूलेलm

minex্ণ

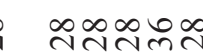

సి

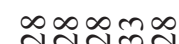

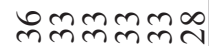

ำำ

어안하

ตलmmल

mmmmo

గiలో

त्रक्रले

लेलmलॅ

ิํํํ

寸노ำ

m가워요

लेmలో

अ लmलm

m

กำ लेलेले

ถ⿻ำกำ

華苾 66

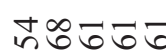

nกmm

trmmm

\%

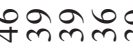

$\hat{n}$

हेलेलेत

본즈

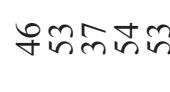

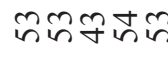

กิํํतำ

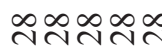
nmomo

gกnูn

斗解然

nmmmm

$\circ$

mmmas

하요

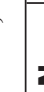

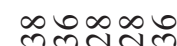

mmmm

ク゚吕扵

オ寸寸立

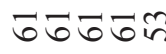

लेलेलेलेलेल

오ำ

○007

Grininis

$-m+t$

$\theta t+t$

タタす゚す

+나에

$\bar{n} 6 \mathrm{~m}$

0

㟧

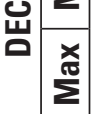

ิํํำ

수수수

নतㅠ్ㅠ

ำำษ

寺

.

nnopo

in 6 +

๓ோரோ

구수

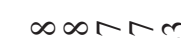

ตñnต

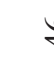

$6060 m$

ヘンタオン

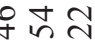

ㄴํㅇ

กำำ

웅에

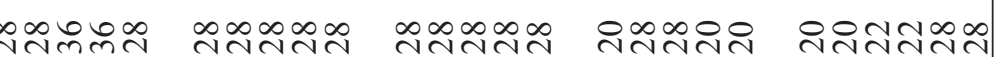

00000

00006

Nतथ

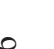

ヘ

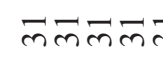

ஜํํำ

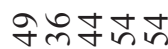

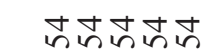

$\infty$

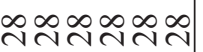

i $\infty$

๓ோோர

గimmin

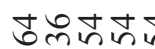

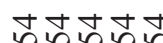

茂芯芯芯芯

पुष्ठ

-Nm+in

orma으는

으으으

文

ingun

ニッำ

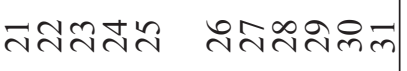

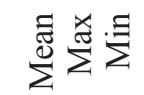


Table 19. Daily mean dissolved-oxygen concentration, Delaware River at Benjamin Franklin Bridge at Philadelphia, Pennsylvania (station number 01467200), April 1 to November 30, 2006.

(U.S. Geological Survey published record)

[Concentrations in milligrams per liter; Max, maximum value; Min, minimum value; ---, missing data]

\begin{tabular}{|c|c|c|c|c|c|c|c|c|}
\hline DAY & APR & MAY & JUNE & JULY & AUG & SEPT & OCT & NOV \\
\hline 1 & 11.5 & 7.8 & 6.7 & 6.6 & 4.4 & 4.7 & 6.2 & 9.7 \\
\hline 2 & 11.7 & 7.7 & 6.8 & 7.0 & --- & 5.7 & 6.2 & 9.7 \\
\hline 3 & 11.6 & 7.7 & 6.1 & 6.9 & --- & 6.4 & 6.5 & 9.9 \\
\hline 4 & 11.5 & 7.8 & 5.7 & 6.7 & --- & 6.6 & 6.4 & 9.8 \\
\hline 5 & 11.6 & 7.7 & 5.1 & 6.4 & --- & 6.4 & 6.6 & 9.8 \\
\hline 6 & 11.6 & 7.7 & 4.8 & 6.3 & --- & 6.1 & 6.6 & 9.7 \\
\hline 7 & 11.5 & 7.7 & 4.4 & 6.4 & --- & 5.8 & 6.8 & 9.7 \\
\hline 8 & 11.1 & 7.6 & 4.0 & 6.4 & 4.3 & 5.5 & 7.0 & 9.5 \\
\hline 9 & 10.9 & 7.5 & 4.0 & 6.4 & 4.4 & 5.3 & 7.0 & 9.8 \\
\hline 10 & 10.6 & 7.1 & 4.3 & 6.4 & 4.4 & 5.2 & 6.8 & 9.7 \\
\hline 11 & 10.2 & 6.7 & 4.8 & 6.3 & 4.3 & 5.2 & 6.6 & 8.8 \\
\hline 12 & 9.6 & --- & 4.9 & 6.1 & 4.3 & 5.1 & 6.3 & 8.5 \\
\hline 13 & 9.1 & --- & 4.9 & 6.0 & 4.3 & 5.0 & 6.6 & 8.4 \\
\hline 14 & 8.9 & --- & 4.9 & 6.0 & 4.3 & 4.9 & 6.8 & 8.5 \\
\hline 15 & 8.6 & --- & 5.0 & 6.1 & 4.5 & 4.8 & 6.8 & 8.7 \\
\hline 16 & 8.5 & 6.2 & 5.1 & 5.9 & 4.4 & 5.1 & 6.8 & 8.6 \\
\hline 17 & 8.5 & 6.4 & 5.3 & 5.7 & 4.5 & 5.6 & 6.7 & 8.4 \\
\hline 18 & 8.4 & 6.5 & 5.6 & 5.5 & 4.4 & 6.2 & 6.5 & 8.8 \\
\hline 19 & 8.3 & 6.5 & 5.9 & 5.4 & 4.4 & 6.7 & 6.6 & 8.6 \\
\hline 20 & 8.3 & 6.8 & 5.9 & 5.5 & 4.5 & 6.8 & 6.6 & 8.7 \\
\hline 21 & 8.5 & 7.1 & 5.8 & 5.3 & 4.5 & 7.0 & 6.9 & 9.1 \\
\hline 22 & 8.5 & 7.4 & 5.6 & 5.2 & 4.6 & 6.9 & 7.4 & 9.6 \\
\hline 23 & 8.1 & 7.4 & 5.4 & 5.1 & 4.5 & 6.8 & 7.6 & 9.9 \\
\hline 24 & 7.8 & 7.3 & 5.1 & 4.7 & 4.5 & 6.7 & 8.0 & 10.2 \\
\hline 25 & 7.4 & 7.4 & 5.0 & 4.6 & 4.3 & 6.4 & 8.2 & 10.6 \\
\hline 26 & 6.9 & 7.1 & 4.7 & 4.8 & 4.2 & 6.2 & 8.3 & 10.6 \\
\hline 27 & 7.0 & 7.0 & 4.6 & 4.8 & 4.2 & 6.1 & 8.5 & 10.6 \\
\hline 28 & 7.3 & 7.3 & 5.3 & 4.8 & 4.3 & 6.0 & 8.5 & 10.6 \\
\hline 29 & 7.5 & 7.2 & 5.8 & 4.6 & 3.9 & 6.1 & 9.5 & 10.6 \\
\hline 30 & 7.7 & 7.2 & 6.3 & 4.5 & 3.7 & 6.2 & 9.8 & 10.6 \\
\hline 31 & & 6.8 & & 4.4 & 3.9 & & 9.6 & \\
\hline Mean & 9.3 & 7.2 & 5.3 & 5.7 & 4.3 & 5.9 & 7.2 & 9.5 \\
\hline $\operatorname{Max}$ & 11.7 & 7.8 & 6.8 & 7.0 & 4.6 & 7.0 & 9.8 & 10.6 \\
\hline Min & 6.9 & 6.2 & 4.0 & 4.4 & 3.7 & 4.7 & 6.2 & 8.4 \\
\hline
\end{tabular}


Table 20. Daily mean dissolved-oxygen concentration, Delaware River at Chester, Pennsylvania (station number 01477050), April 1 to November 30, 2006.

(U.S. Geological Survey published record)

[Concentrations in milligrams per liter; Max, maximum value; Min, minimum value; ---, missing data]

\begin{tabular}{|c|c|c|c|c|c|c|c|c|}
\hline DAY & APR & MAY & JUNE & JULY & AUG & SEPT & OCT & NOV \\
\hline 1 & 9.9 & 6.9 & 6.5 & 7.1 & 5.0 & 5.6 & 6.4 & 9.7 \\
\hline 2 & 9.7 & 6.9 & 6.4 & 7.1 & 4.8 & 6.7 & 6.4 & 9.8 \\
\hline 3 & 9.4 & 7.0 & 6.0 & 7.0 & 4.6 & 6.0 & 6.2 & 10.0 \\
\hline 4 & 9.4 & 7.0 & 5.6 & 6.8 & 4.6 & 5.7 & 6.0 & 10.1 \\
\hline 5 & 9.5 & 7.0 & 5.5 & 6.6 & 4.6 & 5.7 & 6.1 & 10.1 \\
\hline 6 & 9.5 & 7.1 & 5.5 & 6.6 & 4.8 & 5.7 & 6.4 & 10.1 \\
\hline 7 & 9.3 & 7.2 & 5.4 & 6.4 & 5.0 & 5.5 & --- & --- \\
\hline 8 & --- & 7.3 & 5.2 & 6.1 & 5.0 & 5.2 & --- & --- \\
\hline 9 & --- & 7.6 & 4.9 & 5.9 & 5.0 & 5.2 & --- & --- \\
\hline 10 & --- & 7.4 & 4.8 & 5.9 & 5.2 & 5.2 & --- & 9.5 \\
\hline 11 & 9.0 & 7.4 & 5.1 & 5.7 & 5.4 & 5.5 & --- & 9.4 \\
\hline 12 & 8.8 & 7.5 & 5.2 & 5.5 & 5.4 & 5.8 & 6.9 & 9.5 \\
\hline 13 & 8.7 & 7.1 & 5.1 & 5.4 & 5.3 & 5.8 & 7.0 & 9.6 \\
\hline 14 & 8.4 & 6.9 & 4.9 & 5.2 & 5.5 & 5.8 & 7.1 & 9.3 \\
\hline 15 & 8.0 & 7.0 & 4.7 & 5.1 & 5.7 & 5.7 & 7.3 & 8.8 \\
\hline 16 & 7.9 & 6.5 & 4.7 & 4.8 & 5.6 & 5.4 & 7.3 & 8.8 \\
\hline 17 & 7.7 & 6.3 & 4.7 & 4.8 & 5.5 & 5.4 & 7.5 & 9.0 \\
\hline 18 & 7.6 & 6.1 & 4.8 & 4.7 & 5.1 & 5.4 & 7.5 & 9.2 \\
\hline 19 & 7.5 & 5.8 & 4.9 & 4.7 & 5.0 & 5.4 & 7.0 & 9.2 \\
\hline 20 & 7.4 & 6.0 & 5.1 & 4.8 & 5.2 & 5.5 & --- & 9.6 \\
\hline 21 & 7.5 & 6.2 & 5.0 & 4.7 & 5.3 & 5.8 & --- & 10.0 \\
\hline 22 & 8.0 & 6.5 & 4.9 & 4.8 & 5.3 & 5.8 & --- & 10.0 \\
\hline 23 & 7.9 & 6.6 & 4.8 & 4.8 & 5.2 & 6.0 & --- & 10.4 \\
\hline 24 & 7.3 & 6.6 & 4.8 & 4.6 & 5.2 & 6.0 & 9.0 & 10.6 \\
\hline 25 & 6.9 & 6.5 & 4.6 & 4.7 & 5.2 & 6.2 & 8.8 & 10.8 \\
\hline 26 & 6.9 & 6.3 & 4.8 & 4.6 & 5.4 & 6.3 & 8.8 & 10.9 \\
\hline 27 & 6.8 & 6.1 & 5.3 & 4.7 & 5.6 & 6.3 & 8.4 & 11.2 \\
\hline 28 & 6.7 & 6.0 & 5.6 & 4.8 & 5.5 & 6.3 & 8.8 & 11.2 \\
\hline 29 & 6.6 & 6.1 & 6.3 & 4.9 & 5.0 & 6.5 & 9.6 & 11.2 \\
\hline 30 & 6.7 & 6.1 & 7.0 & 4.9 & 4.8 & 6.5 & 9.8 & 11.2 \\
\hline 31 & & 6.3 & & 4.9 & 4.8 & & 9.7 & \\
\hline Mean & 8.1 & 6.7 & 5.3 & 5.4 & 5.1 & 5.8 & 7.6 & 10.0 \\
\hline Max & 9.9 & 7.6 & 7.0 & 7.1 & 5.7 & 6.7 & 9.8 & 11.2 \\
\hline Min & 6.6 & 5.8 & 4.6 & 4.6 & 4.6 & 5.2 & 6.0 & 8.8 \\
\hline
\end{tabular}




\title{
Appendix A
}

\author{
Rainfall Event Based \\ Temporary Spill Reduction Program \\ for \\ Pepacton Reservoir \\ February 8, 2006
}

On April 21, 2004, the Parties to the 1954 U.S. Supreme Court Decree (Decree Parties) approved an interim program for managing releases from the New York City Delaware Basin reservoirs. That interim program was embodied in Delaware River Basin Commission (DRBC) Resolution No. 2004-3 Docket No. D-77-20 (Revision 7). In approving that resolution, the Decree Parties committed to continuing discussions to develop and implement by May 31, 2007 a long-term flexible program to manage releases from the City Delaware Basin reservoirs to better address fisheries in the tailwaters below those reservoirs; the Decree Parties agreed that implementation of such a program required consideration of other related issues.

The Decree Parties agree that reduction of Pepacton Reservoir spill during flood events is a related issue that should be considered in the development of the long-term flexible program. The Decree Parties also agree that reduction of Pepacton Reservoir spill should not be delayed until final approval of a long-term flexible program occurs, and hereby agree to implement a temporary spill reduction program for the period ending March 31, 2006.

During active hydrologic conditions that result in full or nearly full storage in Pepacton Reservoir and overall in the New York City (NYC) Delaware Basin Reservoirs, the temporary spill reduction program described below will be implemented to reduce the volume of water spilled from Pepacton Reservoir. The program will attempt to manage a storage void to completely capture runoff produced by a one inch rainfall event, based on the National Weather Service's Upper Delaware Basin Water Supply Guidance for the reservoir's watershed (see sample guidance statement at 7., below), through supplemental releases above normal conservation rates from the East Delaware Release Chamber. The void shall be maintained during the period ending March 31, 2006. This temporary program is not part of any regular release program and does not establish a precedent for any future releases or actions.

Although the total volume of water spilled from Pepacton Reservoir may be reduced by this temporary program, it is unlikely that peak flows downstream will be significantly reduced. Pepacton Reservoir provides substantial attenuation of peak flows downstream even when the reservoir is spilling. The reservoir was not designed as a flood control reservoir and does not contain release works capable of releasing water at rates necessary for effective flood management operation; consequently, the Decree Parties continue to strongly urge communities downstream of the reservoir to take all necessary and prudent actions to improve flood preparedness and increase awareness of flood potential.

Temporary Pepacton Reservoir Spill Reduction Program:

1. Upon approval of this agreement by the Decree Parties, the City of New York will implement a temporary program to achieve limited reduction of Pepacton Reservoir storage through supplemental releases from the East Delaware Release Chamber.

2. For the period ending March 31, 2006, whenever the void in Pepacton Reservoir is less than the expected runoff volume that would result from a one inch rainfall event as predicted by the National Weather Service's Upper Delaware Basin Water Supply Guidance, supplemental releases will be made as necessary to maintain to the extent practicable, a void sufficient to completely capture the runoff volume forecasted for a one inch rainfall event.

3. The recommended rate of the supplemental release shall be established daily by NYC in consultation with the Delaware River Master. Releases above the normal conservation rate will be accounted for as 
special releases and be considered neither River Master directed releases nor conservation releases in accordance with DRBC Docket D-77-20 (Revision 7).

4. The River Master will manage the recommended supplemental releases in such a manner as to conserve the waters of the Delaware Basin in accordance with the following guidance:

i. The flood stage for the East Branch Delaware River at Fishs Eddy is 13 feet. Accordingly, supplemental releases will not be made when the river stage for the East Branch Delaware River at Fishs Eddy is above 11 feet, or is forecasted to be above 11 feet within 48 hours of a planned supplemental release from Pepacton Reservoir. This guidance may be modified at any time if additional information demonstrates that a lower cautionary stage should be used to limit the supplemental releases.

ii. Supplemental releases may be suspended if ice conditions threaten flood prone areas of the East Branch Delaware River below Pepacton Reservoir.

iii. Supplemental releases will be designed so that the combined discharge from the East Delaware Release Chamber and the Downsville Dam spillway does not exceed 2,000 cubic feet per second (cfs). All supplemental releases will be discontinued when the spillway discharge exceeds 2,000 cfs.

5. This temporary program will be run concurrently with the existing snowpack-based spill reduction program. Voids maintained under the two programs shall not be additive.

6. If releases are made pursuant to this program and Pepacton Reservoir fails to reach $99 \%$ storage prior to the start of drawdown, the difference between the actual reservoir storage at the start of drawdown and the full capacity of the reservoir will be deducted from NYC's authorized Delaware Basin diversion for the upcoming hydrological year (i.e., year beginning June 1, 2006).

7. Example of National Weather Service Product:

http ://www.srh.noaa.gov/productview.php?pil=FFHPA2

UPPER DELAWARE BASIN WATER SUPPLY GUIDANCE

APPROXIMATE RUNOFF (IN MILLIONS OF GALLONS) PRODUCED FROM EACH OF THE FOLLOWING 6-HOUR RAINFALL AMOUNTS (IN INCHES):

\begin{tabular}{|c|c|c|c|c|c|c|c|}
\hline \multirow[b]{2}{*}{ :IDENT } & \multicolumn{4}{|c|}{ RAINFALL } & \multirow[b]{2}{*}{3.0} & \multirow[b]{2}{*}{5.0} & \multirow[b]{2}{*}{ LOCATION } \\
\hline & 0.1 & 0.5 & 1.0 & 2.0 & & & \\
\hline CANN6DEL & $470 /$ & 2398/ & $4833 /$ & $10303 /$ & $16190 /$ & 27962 & :CANNONSVILLE \\
\hline DWNN6DEL & $422 /$ & $2237 /$ & $4590 /$ & 9857/ & $15318 /$ & 26238 & : PEPACTON \\
\hline $\begin{array}{l}\text { NVRN6NVR } \\
\text {.END }\end{array}$ & $28 /$ & $311 /$ & $666 /$ & $1494 /$ & $2459 /$ & 4403 & :NEVERSINK \\
\hline
\end{tabular}

8. This agreement will expire on May 31, 2007 and may be terminated at any time at the request of any Decree Party or may be modified with the unanimous consent of the Decree Parties. 


\section{Consent to Action by The City of New York}

Consent of the Parties to the U.S. Supreme Court Decree in New Jersey v. New York, 347 U.S. 995 (1954), approving the Pepacton Reservoir Temporary Spill Reduction Program, February 8, 2006 through May 31, 2007, implemented by the City of New York.

$\overline{\text { State of New Jersey } \quad \text { Date }}$

State of Delaware

Date

State of Delaware
Date
State of New York

Date

$\overline{\text { Commonwealth of Pennsylvania } \quad \text { Date }}$

City of New York

Date 


\title{
Appendix B
}

\author{
Rainfall Event Based \\ Temporary Spill Reduction Program \\ for \\ Neversink Reservoir \\ February 8, 2006
}

On April 21, 2004, the Parties to the 1954 U.S. Supreme Court Decree (Decree Parties) approved an interim program for managing releases from the New York City Delaware Basin reservoirs. That interim program was embodied in Delaware River Basin Commission (DRBC) Resolution No. 2004-3 Docket No. D-77-20 (Revision 7). In approving that resolution, the Decree Parties committed to continuing discussions to develop and implement by May 31, 2007 a long-term flexible program to manage releases from the City Delaware Basin reservoirs to better address fisheries in the tailwaters below those reservoirs; the Decree Parties agreed that implementation of such a program required consideration of other related issues.

The Decree Parties agree that reduction of Neversink Reservoir spill during flood events is a related issue that should be considered in the development of the long-term flexible program. The Decree Parties also agree that reduction of Neversink Reservoir spill should not be delayed until final approval of a long-term flexible program occurs, and hereby agree to implement a temporary spill reduction program for the period ending March 31, 2006.

During active hydrologic conditions that result in full or nearly full storage in Neversink Reservoir and overall in the New York City (NYC) Delaware Basin Reservoirs, the temporary spill reduction program described below will be implemented to reduce the volume of water spilled from Neversink Reservoir. The program will attempt to manage a storage void to completely capture runoff produced by a one inch rainfall event, based on the National Weather Service's Upper Delaware Basin Water Supply Guidance for the reservoir's watershed (see sample guidance statement at 7., below), through supplemental releases above normal conservation rates from the Neversink Release Chamber. The void shall be maintained during the period ending March 31, 2006. This temporary program is not part of any regular release program and does not establish a precedent for any future releases or actions.

Although the total volume of water spilled from Neversink Reservoir may be reduced by this temporary program, it is unlikely that peak flows downstream will be significantly reduced. Neversink Reservoir provides substantial attenuation of peak flows downstream even when the reservoir is spilling. The reservoir was not designed as a flood control reservoir and does not contain release works capable of releasing water at rates necessary for effective flood management operation; consequently, the Decree Parties continue to strongly urge communities downstream of the reservoir to take all necessary and prudent actions to improve flood preparedness and increase awareness of flood potential.

\section{Temporary Neversink Reservoir Spill Reduction Program:}

1. Upon approval of this agreement by the Decree Parties, the City of New York will implement a temporary program to achieve limited reduction of Neversink Reservoir storage through supplemental releases from the Neversink Release Chamber.

2. For the period ending March 31, 2006, whenever the void in Neversink Reservoir is less than the expected runoff volume that would result from a one inch rainfall event as predicted by the National Weather Service's Upper Delaware Basin Water Supply Guidance, supplemental releases will be made as necessary to maintain to the extent practicable, a void sufficient to completely capture the runoff volume forecasted for a one inch rainfall event.

3. The recommended rate of the supplemental release shall be established daily by NYC in consultation with the Delaware River Master. Releases above the normal conservation rate will be accounted for as special releases and be considered neither River Master directed releases nor conservation releases in accordance with DRBC Docket D-77-20 (Revision 7). 
4. The River Master will manage the recommended supplemental releases in such a manner as to conserve the waters of the Delaware Basin in accordance with the following guidance:

i. The flood stage for the Neversink River at Bridgeville is 8 feet. Accordingly, supplemental releases will not be made when the river stage for the Neversink River at Bridgeville is above 6 feet, or is forecasted to be above 6 feet within 48 hours of a planned supplemental release from Neversink Reservoir. This guidance may be modified at any time if additional information demonstrates that a lower cautionary stage should be used to limit the supplemental releases.

ii. Supplemental releases may be suspended if ice conditions threaten flood prone areas of the Neversink River below Neversink Reservoir.

iii. Supplemental releases will be designed so that the combined discharge from the Neversink Release Chamber and the Neversink Dam spillway does not exceed 750 cubic feet per second (cfs). All supplemental releases will be discontinued when the spillway discharge exceeds $750 \mathrm{cfs}$.

5. This temporary program will be run concurrently with the existing snowpack-based spill reduction program. Voids maintained under the two programs shall not be additive.

6. If releases are made pursuant to this program and Neversink Reservoir fails to reach $99 \%$ storage prior to the start of drawdown, the difference between the actual reservoir storage at the start of drawdown and the full capacity of the reservoir will be deducted from NYC's authorized Delaware Basin diversion for the upcoming hydrological year (i.e., year beginning June 1, 2006).

7. Example of National Weather Service Product:

http ://www.srh.noaa.gov/productview.php?pil=FFHPA2

UPPER DELAWARE BASIN WATER SUPPLY GUIDANCE

APPROXIMATE RUNOFF (IN MILLIONS OF GALLONS) PRODUCED FROM EACH OF THE FOLLOWING 6-HOUR RAINFALL AMOUNTS (IN INCHES):

\begin{tabular}{|c|c|c|c|c|c|c|c|}
\hline \multirow[b]{2}{*}{ :IDENT } & \multicolumn{6}{|c|}{ RAINFALL } & \multirow[b]{2}{*}{ LOCATION } \\
\hline & 0.1 & 0.5 & 1.0 & 2.0 & 3.0 & 5.0 & \\
\hline OEL & $470 /$ & $2398 /$ & $4833 /$ & $10303 /$ & $16190 /$ & 27962 & :CANI \\
\hline VNN6DEL & $422 /$ & $2237 /$ & $4590 /$ & 9857/ & 15318/ & 26238 & : PEPACTON \\
\hline VRN6NVR & $28 /$ & 311/ & $666 /$ & 1494/ & $2459 /$ & 4403 & :NEVERSINK \\
\hline
\end{tabular}

.END

$\$ \$$

8. This agreement will expire on May 31, 2007 and may be terminated at any time at the request of any Decree Party or may be modified with the unanimous consent of the Decree Parties. 


\section{Consent to Action by The City of New York}

Consent of the Parties to the U.S. Supreme Court Decree in New Jersey v. New York, 347 U.S. 995 (1954), approving the Neversink Reservoir Temporary Spill Reduction Program, February 8, 2006 through May 31, 2007, implemented by the City of New York.

State of New Jersey Date

State of Delaware

Date

State of Delaware

Date

State of New York

Date

$\overline{\text { Commonwealth of Pennsylvania } \text { Date }}$

City of New York

Date 


\title{
Appendix C
}

\author{
NO. 2006-18 \\ DOCKET NO. D-77-20 CP (Revision 9)
}

A RESOLUTION supplementing and amending Docket No. D-77-20 CP (Revisions 7 and 8) to establish a temporary spill mitigation program for Neversink, Pepacton and Cannonsville Reservoirs.

WHEREAS, on April 21, 2004, the Delaware River Basin Commission (DRBC) with the unanimous consent of the Parties to the 1954 Supreme Court Decree (Decree Parties) adopted Resolution No. 2004-3, Docket No. D-77-20 CP (Revision 7), establishing an interim program for managing releases from the New York City Neversink, Pepacton and Cannonsville Reservoirs (NYC Delaware Basin Reservoirs);

WHEREAS, on July 13, 2004, the DRBC adopted Resolution No. 2004-9, Docket No. D-77-20 CP (Revision 8), amending Docket No. D-77-20 CP (Revision 7) to allow a portion of the Excess Release Quantity established by the 1954 Supreme Court Decree to be used for purposes of aquatic resource research related to fisheries enhancement, including dwarf wedgemussel studies;

WHEREAS, through Resolution No. 2004-3 the Decree Parties committed to continuing discussions to develop and implement by May 31, 2007 a long-term flexible program to manage releases from the NYC Delaware Basin Reservoirs to better address fisheries and other needs in the tailwaters below these reservoirs;

WHEREAS, in Resolution No. 2004-3 the Decree Parties agreed that the long-term program must take into account related issues including but not limited to those issues specified in this Resolution;

WHEREAS, reduction of spill volumes from the NYC Delaware Basin Reservoirs during flood events is a related issue under consideration in the development of the long-term flexible program;

WHEREAS, the Commission and Decree Parties believe that implementation of a temporary spill mitigation program through May 31, 2007 may reduce excess spillage through supplemental releases from the NYC Delaware Basin Reservoirs and should not be delayed until final approval of a long-term flexible program occurs;

WHEREAS, the NYC Delaware Basin Reservoirs already provide substantial attenuation of peak flows downstream even when one or more of the reservoirs is spilling; and

WHEREAS, an interim spill mitigation program has the potential to reduce spill rates and offer a small measure of peak flow reduction during a flood event, although any such reduction will diminish with increasing distance downstream of the Cannonsville, Pepacton, and Neversink dams;

WHEREAS, the NYC Delaware Basin Reservoirs were not designed as flood control reservoirs and do not contain release works capable of releasing water at rates necessary for effective flood management operation;

WHEREAS, notwithstanding this temporary spill mitigation program the DRBC and the Decree Parties strongly encourage communities and individuals downstream of the NYC Delaware Basin Reservoirs to take all necessary and prudent actions to improve flood preparedness and increase awareness of flood potential;

WHEREAS, in light of the only limited flood mitigation benefits achievable through this spill mitigation program and the benefits to the Basin community from better flood management information and flood control, through a concurrent resolution Pennsylvania, New Jersey, New York and Delaware have 
agreed to share the cost of developing a model to study more broadly and thoroughly the potential effects of managing reservoirs throughout the Basin to reduce flooding in the Delaware River and its tributaries;

WHEREAS, the Commission intends to form a task force to examine stormwater management, landuse patterns, open space and farmland preservation, floodplain regulations and other potential non-structural flood mitigation measures in the Basin; and

WHEREAS, New York City with the consent of the other Decree Parties commenced implementation of a temporary spill mitigation program on September 22, 2006, subject to further action by the DRBC; now therefore

BE IT RESOLVED by the undersigned Commissioners and Decree Parties:

1. For the period ending May 31, 2007, whenever the usable storage in the NYC Delaware Basin Reservoirs is above the $80 \%$ rule curve as shown in Figure 1, in lieu of the releases otherwise required under Docket D-77-20 (Revision 7), supplemental releases from the NYC Delaware Basin Reservoirs will be made in accordance with the individual rule curves shown on Figure 2 and at rates as shown in Table 1. In order to provide for such releases, it is agreed that the operational assumptions used for modeling analyses and stipulated in paragraph 2 will apply throughout the period this program remains in effect.

2. The releases under this program have been modeled using the OASIS model and are based upon an operational assumption of a running daily average diversion by the City of not more than $610 \mathrm{mgd}$, combined, from the NYC Delaware Basin Reservoirs. The habitat flow targets, in accordance with Revision 7, continue to apply when storage is above the $80 \%$ rule curve. 
Figure 1

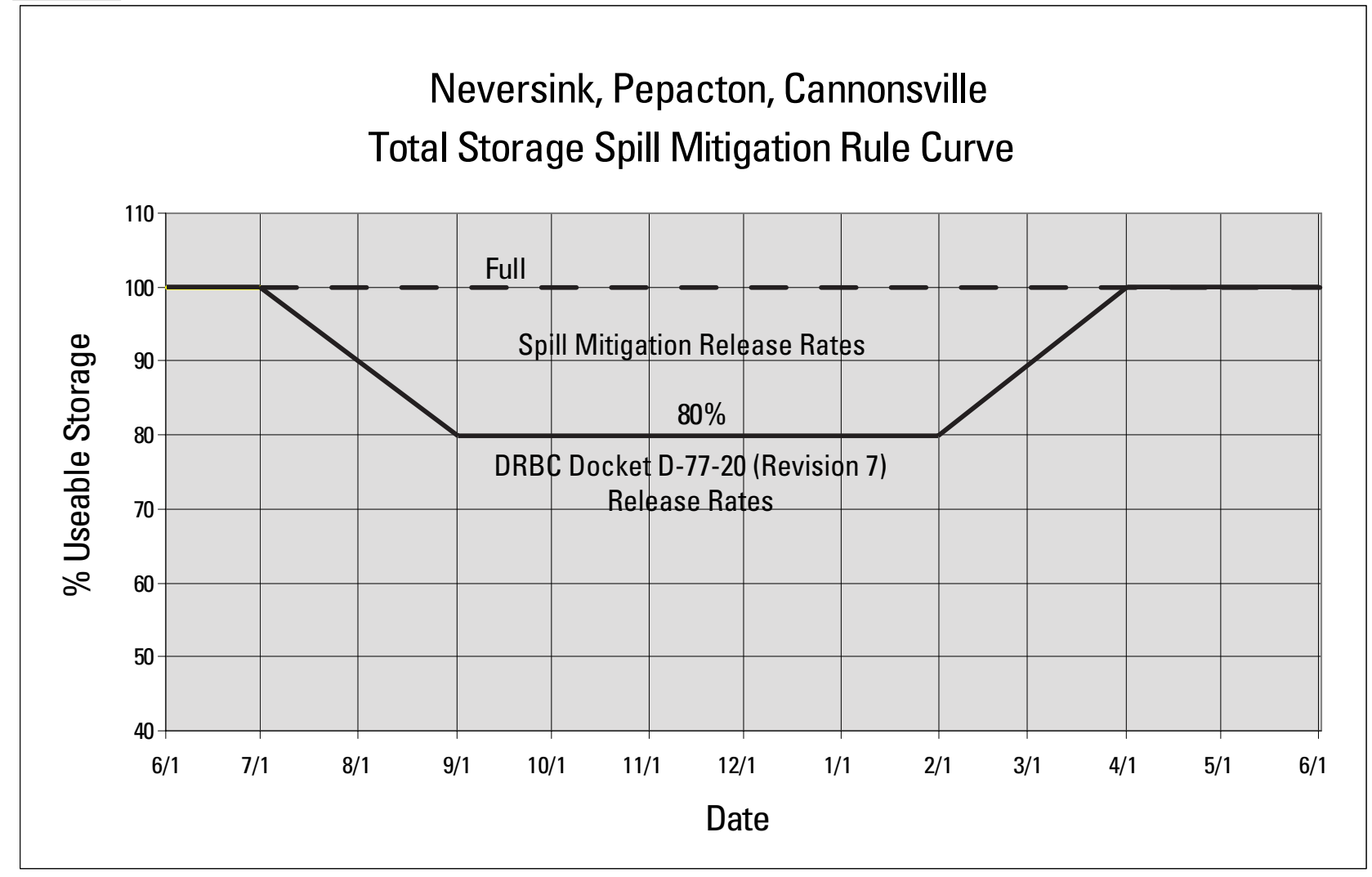

Figure 2

Neversink, Pepacton, Cannonsville Spill Mitigation Rule Curves

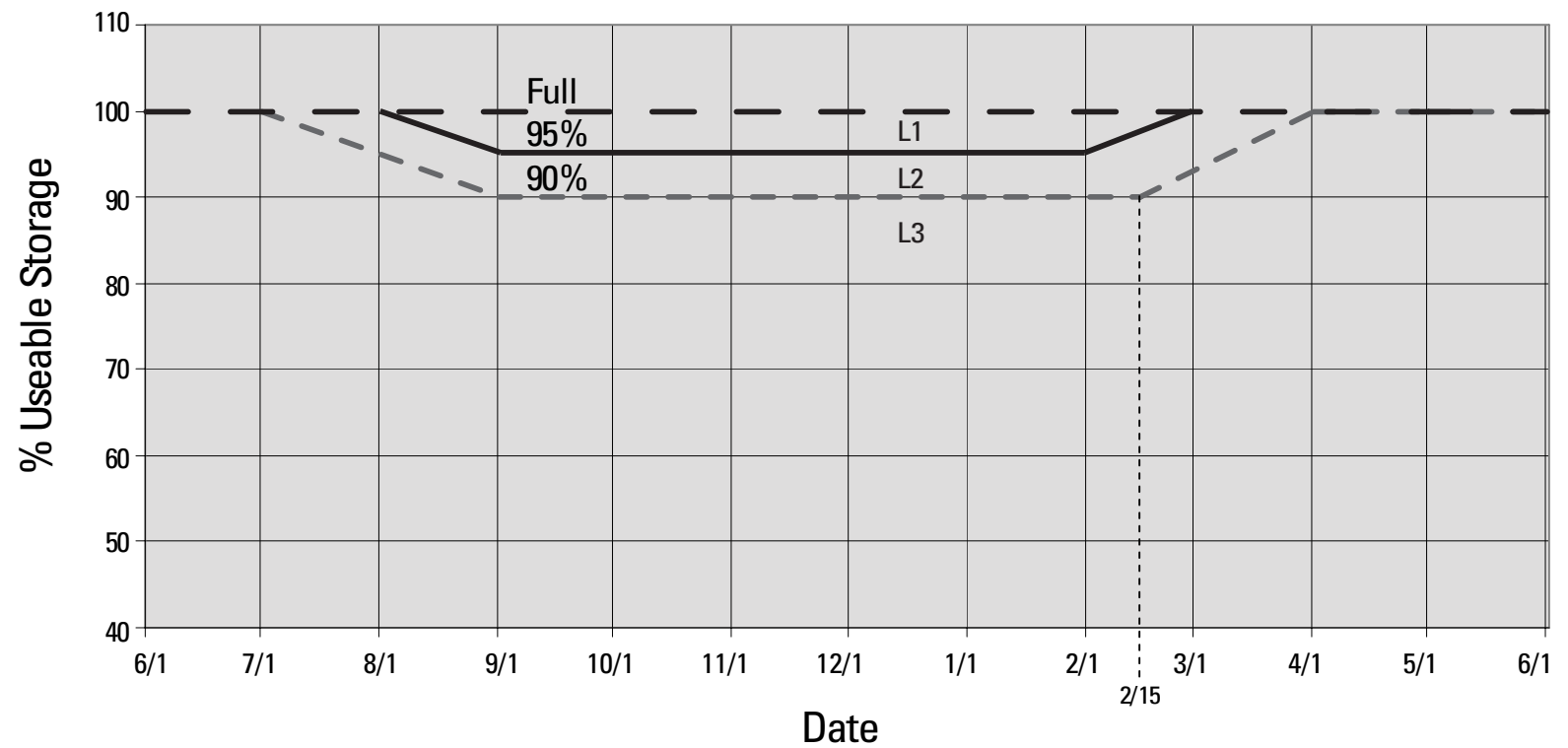


Table 1

\begin{tabular}{|c|c|c|c|c|c|c|}
\hline \multirow{2}{*}{$\begin{array}{c}\text { Release } \\
\text { Level }\end{array}$} & \multicolumn{5}{|c|}{ Release Rates (cfs) } \\
\cline { 2 - 7 } & \multicolumn{3}{|c|}{ Spring/Fall } & \multicolumn{3}{c|}{ Winter } \\
\hline & Cannonsville & Pepacton & Neversink & Cannonsville & Pepacton & Neversink \\
\hline L1 & 1000 & 700 & 190 & 1000 & 700 & 190 \\
\hline L2 & 275 & 200 & 85 & 250 & 185 & 85 \\
\hline L3 & 140 & 100 & 75 & 110 & 85 & 65 \\
\hline
\end{tabular}

Spring/Fall: $\quad$ May 1 - May 31 and Sept 15 - Sept 30

Winter: $\quad$ October 1 - April 30

3. Controlled reservoir releases will be made in accordance with the following:

i. The flood stage for the West Branch Delaware River at Hale Eddy is 11 feet. Accordingly, supplemental releases from Cannonsville Reservoir will not be made when the river stage for the West Branch Delaware River at Hale Eddy is above 9 feet, or is forecasted to be above 9 feet within 48 hours of a planned supplemental release from Cannonsville Reservoir. This guidance may be modified at any time if additional information demonstrates that a lower cautionary stage should be used to limit the supplemental releases.

ii. The flood stage for the East Branch Delaware River at Fishs Eddy is $15.0 \mathrm{ft}$. Accordingly, supplemental releases will not be made when the river stage for the East Branch Delaware River at Fishs Eddy is above $13.0 \mathrm{ft}$. or is forecast to be above $13.0 \mathrm{ft}$. within 48 hours of a planned supplemental release from Pepacton Reservoir. This guidance may be modified at any time if additional information demonstrates that a lower cautionary stage should be used to limit the supplemental releases.

iii. The flood stage for the Neversink River at Bridgeville is 8 feet. Accordingly, supplemental releases will not be made when the river stage for the Neversink River at Bridgeville is above 6 feet, or is forecast to be above 6 feet within 48 hours of a planned supplemental release from Neversink Reservoir. This guidance may be modified at any time if additional information demonstrates that a lower cautionary stage should be used to limit the supplemental releases.

iv. Supplemental releases may be suspended from the respective reservoir if ice conditions threaten flood prone areas of the Neversink River below Neversink Reservoir, East Branch Delaware River below Pepacton Reservoir, or West Branch Delaware River below Cannonsville Reservoir.

v. Supplemental releases will be designed so that the combined discharge from the reservoirs and their respective spillways do not exceed flow rates as detailed in Table 2 below. All controlled releases will be reduced to the conservation releases in Table 3 when the spillway discharge exceeds these flow rates.

vi. To more naturally effect downward transitions between release levels identified in Figures 1 and 2 and Table 1, supplemental release rates shall be ramped generally over a three-day period at Cannonsville and Pepacton Reservoirs and a two-day period at Neversink Reservoir, but in increments no less than $10 \mathrm{cfs}$ at any reservoir. 
Table 2

\begin{tabular}{|c|c|}
\hline Reservoir & $\begin{array}{c}\text { Maximum Combined } \\
\text { Spill/Release Flow Rate }\end{array}$ \\
\hline Neversink & $1800 \mathrm{cfs}$ \\
\hline Pepacton & $2400 \mathrm{cfs}$ \\
\hline Cannonsville & $2200 \mathrm{cfs}$ \\
\hline
\end{tabular}

$\underline{\text { Table } 3}$

Conservation Releases

\begin{tabular}{|c|c|c|c|c|}
\hline \multirow[b]{2}{*}{ Reservoir } & \multicolumn{4}{|c|}{ _ _ _ _ _ _ _ _ Conservation Release $(c f s) \ldots \ldots$} \\
\hline & $\begin{array}{l}\text { Drought } \\
\text { Normal }\end{array}$ & $\begin{array}{c}\text { Drought } \\
\text { Watch }\end{array}$ & Warning & Drought \\
\hline Cannonsville $(9 / 1-5 / 31)$ & 45 & 38 & 32 & 23 \\
\hline Cannonsville (6/1 - 8/31) & 60 & 51 & 43 & 23 \\
\hline Pepacton & 35 & 30 & 25 & 19 \\
\hline Neversink & 25 & 21 & 18 & 15 \\
\hline
\end{tabular}

4. For the period ending May 31, 2007, whenever the total storage in the NYC Delaware Basin Reservoirs is below the applicable point on the $80 \%$ rule curve as shown in Figure 1, releases from the NYC Delaware Basin Reservoirs will be made and accounted for in accordance with DRBC Docket D-77-20 (Revision 7).

5. For the period ending May 31, 2007, whenever the total storage in the NYC Delaware Basin Reservoirs is above the applicable point on the $80 \%$ rule curve as shown in Figure 1 and supplemental releases are made in accordance with this spill mitigation program, to the extent necessary, habitat releases may be made to meet the habitat flow targets in accordance with DRBC Docket D-77-20 (Revision 7). There shall be no credits or debits to the 'Habitat Protection Bank' as established in Revision 7 including without limitation to the Excess Release Quantity Bank portion of the Habitat Protection Bank provided from the Excess Release Quantity.

6. The "Rainfall Event Based Temporary Spill Reduction Program for Pepacton Reservoir" effective February 8, 2006 and "Rainfall Event Based Temporary Spill Reduction Program for Neversink Reservoir" effective February 8, 2006 are hereby suspended for the effective period of this agreement.

7. The "Interim Program for Neversink Reservoir Spill Reduction" effective November 1, 2005 and the "Interim Program for Pepacton Reservoir Spill Reduction" effective November 1, 2005 are hereby suspended for the effective period of this agreement.

8. A quantity of water no greater than $50 \%$ of the water equivalent of snow pack storage in the watershed above each reservoir will be included in the storage calculation to determine the reservoir release levels in Figure 2 and Table 1.

9. The actions of New York City commencing implementation of the spill mitigation program with the agreement of the other Decree Parties are ratified and approved. 
10. The program established by this Resolution will expire on May 31, 2007 and may be terminated at any time by the Commission or at the request of any Decree Party or may be modified by the Commission with the unanimous consent of the Decree Parties.

/s/ Gwen E. Baker

Lt. Col. Gwen E Baker, Chair pro tem

/s/ Pamela M. Bush

Pamela M. Bush, Esq., Commission Secretary

ADOPTED: September 27, 2006 


\section{Consent to Action by the Decree Parties}

Consent of the Parties to the U.S. Supreme Court Decree in New Jersey v. New York, 347 U.S. 995 (1954), approving the Temporary Spill Mitigation Program for Neversink, Pepacton and Cannonsville Reservoirs, September 27, 2006 through May 31, 2007, implemented by the City of New York.

\begin{tabular}{cc} 
/s/ Samuel A. Wolfe & $9 / 27 / 06$ \\
\hline State of New Jersey & Date
\end{tabular}

/s/ John H. Talley

State of Delaware

9/27/06

Date

\begin{tabular}{cc} 
/s/ Harry W. Otto & $9 / 27 / 06$ \\
\hline State of Delaware & Date
\end{tabular}

\begin{tabular}{cc} 
/s/ Fred Nuffer & $9 / 27 / 06$ \\
\hline State of New York & Date
\end{tabular}

\begin{tabular}{lc} 
/s/ Cathy Curran Myers & 9/27/06 \\
\hline Commonwealth of Pennsylvania & Date
\end{tabular}

\begin{tabular}{lc} 
/s/ Michael A. Principe & 9/27/06 \\
\hline City of New York & Date
\end{tabular} 

8 Printed on recycled paper 